\title{
CURATIVE TREATMENT OF PROSTATE CANCER -
}

A STUDY OF ADVERSE EFFECTS AND ADHERENCE TO GUIDELINES

Andreas Stensvold, MD

Department of Oncology, Division of Cancer, Surgery and Transplantation, Oslo University Hospital, (Norwegian Radium Hospital)

$\&$

Faculty of Medicine, University of Oslo

2012 


\section{(C) Andreas Stensvold, 2012}

Series of dissertations submitted to the Faculty of Medicine, University of Oslo No. 1449

ISBN 978-82-8264-485-3

All rights reserved. No part of this publication may be reproduced or transmitted, in any form or by any means, without permission.

Cover: Inger Sandved Anfinsen.

Printed in Norway: AIT Oslo AS.

Produced in co-operation with Akademika publishing. The thesis is produced by Akademika publishing merely in connection with the thesis defence. Kindly direct all inquiries regarding the thesis to the copyright holder or the unit which grants the doctorate. 


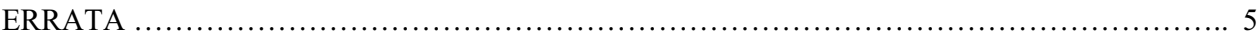

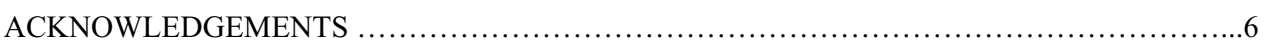

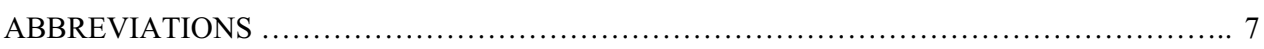

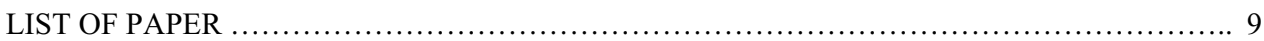

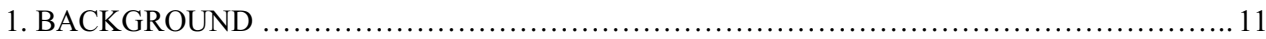

1.1. Incidence, survival, mortality and prevalence ................................................................ 11

1.1.1. Incidence

1.1.2. Survival

1.1.3. Mortality rate

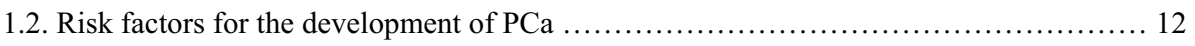

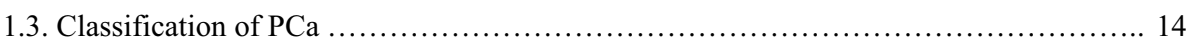

1.3.1. T stage

1.3.2. $\mathrm{N}$ stage

1.3.3. $\mathrm{M}$ category

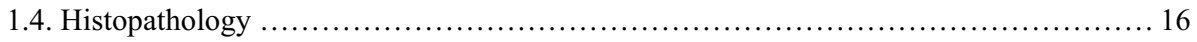

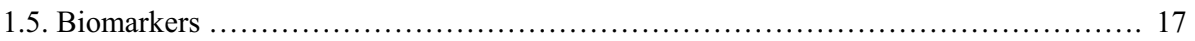

1.5.1. PSA

1.5.2. PSA dynamics (doubling time and velocity)

1.5.3. Follow-up

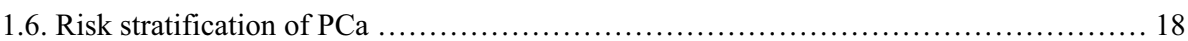

1.7. Treatment modalities ................................................................ 18

1.7.1. AS

1.7.2. WW

1.7.3. Hormone therapy

1.7.4. RP

1.7.5. RAD

1.7.6. RAD after RP

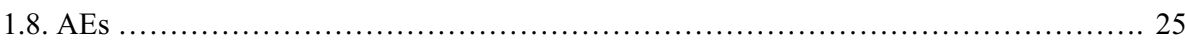

1.8.1. Common AEs after treatment of $\mathrm{PCa}$

\subsubsection{Other AEs}

1.8.3. AEs by treatment modality

1.9. QoL

1.9.1. Insturments to measure disease-specific QoL

1.9.2. New statistical tools to evaluate treatment options

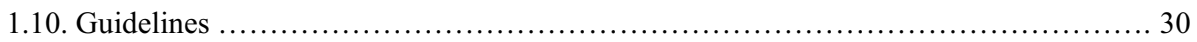

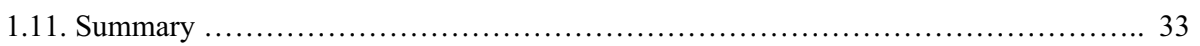




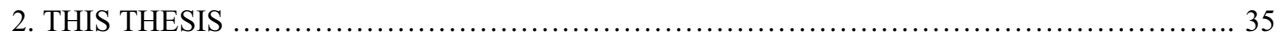

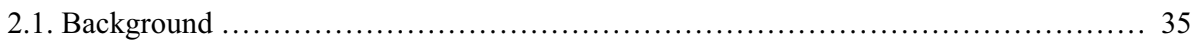

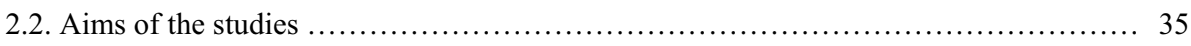

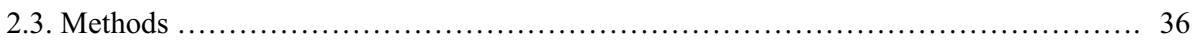

2.3.1. Patient recruitment

2.3.2. Treatment modalities

2.3.3. Periods and adherence to guidelines

2.3.4. Collection of clinical data

2.3.5. Self-report instruments

2.3.6. Statistical considerations

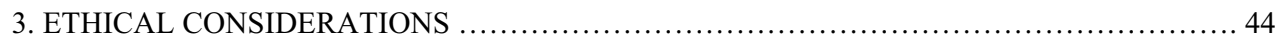

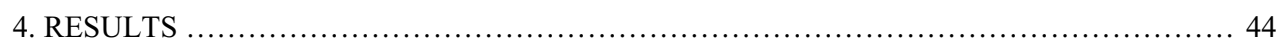

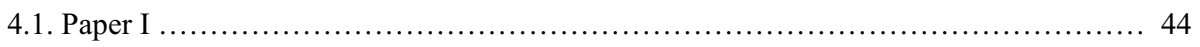

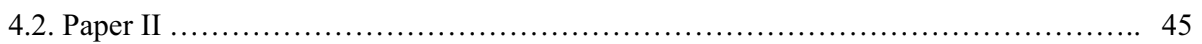

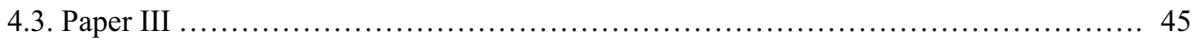

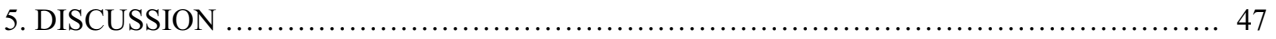

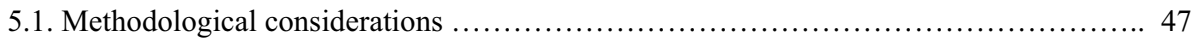

5.1.1. Cross-sectional and longitudinal studies

\subsubsection{Bias}

5.1.3. Internal and external validity

5.2. Discussion of the main findings .............................................. 51

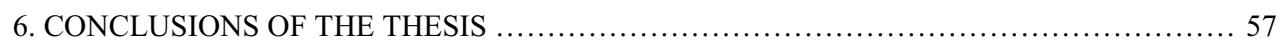

Paper I

Paper II

Paper III

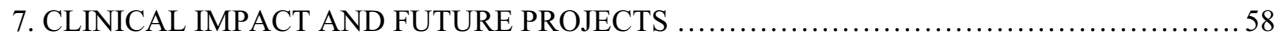

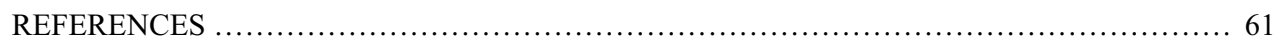

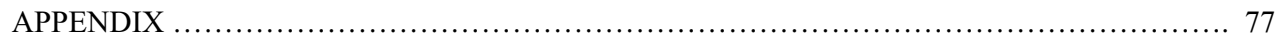

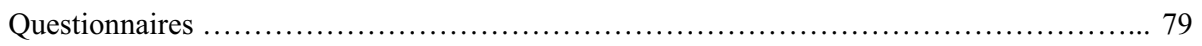

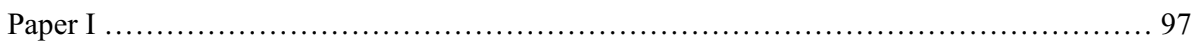

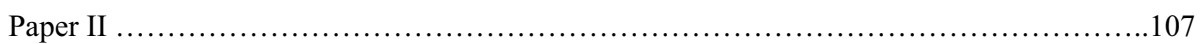

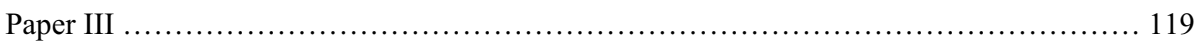




\section{Errata}

Paper I: Reference 13 should be "American Joint Committee on Cancer: Cancer staging manual. New York: Springer; 2002.”

Paper II: The level of statistical significance was set to alpha $=0.01$, should be the lever of.......... alpha $\leq 0.01$

Paper III: Reference 17 should be "Stensvold" instead of "tensvold" 


\section{ACKNOWLEDGEMENTS}

This work was carried out from 2008 to 2012 at the Department of Oncology, Oslo University Hospital, Norwegian Radium Hospital. First and foremost I thank the participating men with prostate cancer and their families for their unselfish contributions.

I also wish to express my sincere gratitude to Professor Sigbjørn S. Smeland, my supervisor and mentor, for your support, guidance and encouragement. Your ability to balance between broad vision and realistic perspective has been of great importance to me. I have really appreciated your patience, constant positive attitude, and interest in my well-being.

Furthermore, I am grateful to my co-supervisors Professor Alv A. Dahl and Professor Sopie D. Fosså at National Resource Center Late Effects after cancer. Professor Dahl has guided me through this project, always being available with wise comments, creativity, quick feedback and willingness to share his knowledge of research and academic writing. Professor Fosså, I thank for her skillful supervision and constructive criticism, which have inspired me throughout this learning process.

I am also grateful to my additional co authors: Dr. Wolfgang Lilleby, Dr. Karol Axcorona, Dr. Bjørn Brennhovd, Andreas Steinsvik and Dr Milada Cvancarova Småstuen, for their important contributions. I want to thank Dr Inger-Lise Nesvold, Dr Jan Oldeburg, Professor Ellen Grov, Dr Sigmund Brabrand and all other fellow researchers. I want also tanks my clleagues, Dr Paal F Brunsvig, Dr Kari DolvenJacobsen and Dr Marius Normann, for their motivating comments during the process.

Most of the work has been done in co-operation with an out patient clinic. This would not have been possible without support from my good colleagues Dr Hilde Roalset, Yvonne Brandal and Professor Nina Aass.

I wish to thank my closest family for what they mean to me. My parents, Solveig and Kjell, who have supported me unconditionally during all phases of life, and my brother and twin sister, Einar and Anne-Kristin and their families.

Finally, I would like to thank my beautiful and beloved wife and best friend, Uzma, for sharing her life with me and for her support during and after the work with this thesis. 


\section{ABBREVIATIONS}

3D-CRT Three-dimensional conformal radiotherapy

ADT Androgen-deprivation therapy

AE Adverse effect

AGREE Appraisal of Guidelines for Research and Evaluation

ANOVA Analysis of variance

AS

Active surveillance

ASTRO American Society for Therapeutic Radiology and Oncology

AUA American Urological Association

BRCA1/2 Breast cancer gen (1 and 2)

$\mathrm{CF} \quad$ Chronic fatigue

CT Computed tomography

DRE Digital rectal examination

EAU European Association of Urology

EBRT Conformal external beam radiotherapy

EORTC European Organisation for Research and Treatment of Cancer

EPIC Expanded Prostate Cancer Index Composite

EPQ-18 Short Version of the Eysenck Personality Questionnaire

FQ Fatigue Questionnaire

GEE Generalized estimating equation

HADS Hospital Anxiety and Depression Scale

HDR-BT High-dose-rate brachytherapy

IGRT Image-guided radiotherapy

IMRT Intensity-modulated radiotherapy

LDR-BT Low-dose-rate brachytherapy

LHRH Luteinizing hormone-releasing hormone

MCS Mental composite summary (score)

MRI Magnetic resonance imaging

NCCN National Comprehensive Cancer Network ${ }^{\circledR}$

NPPC National Program for Prostate Cancer (Norway)

NRH Norwegian Radium Hospital

OR Odds ratio

ORRP Open radical retropubic prostatectomy

PBS Percentage of patients who regained to the baseline function score 
PBS-90 Percentage of patients who regained $90 \%$ of their baseline function score

PBS-100 Percentage of patients who regained their baseline bother score

$\mathrm{PCa} \quad$ Prostate cancer

PCS Physical composite summary (score)

PSA Prostate-specific antigen

PSADT PSA doubling time

QoL Quality of life

RAD Radiotherapy

RALP Robot-assisted laparoscopic prostatectomy

RP Radical prostatectomy

RTOG Radiation Therapy Oncology Group (USA)

SD Standard deviation

SF-12 Short Form-12

SPCG Scandinavian Prostate Cancer Group

TNM Tumor-node-metastasis system

TRUS Transrectal ultrasound

UCLA-PCI University of California at Los Angeles Prostate Composite Index

WW Watchful waiting 


\section{LIST OF PAPERS}

This thesis is based on the following papers, which are referred to in the text by Roman numerals I-III.

\section{Paper I}

Clinicians' use of guidelines as illustrated by curative treatment of prostate cancer at a comprehensive cancer center

Stensvold A, Dahl AA, Fosså SD, Axcrona K, Lilleby W, Brennhovd B, Smeland S.

Acta Oncol 2011 Apr;50(3):408-14.

\section{Paper II}

Methods for prospective studies of adverse effects as applied to prostate cancer patients treated with surgery or radiotherapy without hormones

Stensvold A, Dahl AA, Brennhovd B, Cvancarova M, Fosså SD, Lilleby W, Axcrona K, Smeland S. Prostate 2012 May 1;72(6):668-76.

\section{Paper III}

Bother problems in prostate cancer patients after curative treatment

Stensvold A, Dahl AA, Brennhovd B, Småstuen MC, Fosså SD, Lilleby W, Steinsvik A, Axcrona K, Smeland S.

Urol Oncol 2012 Feb 16. [Epub ahead of print] http://dx.doi.org/10.1016/j.urolonc.2011.12.020 


\section{BACKGROUND}

\subsection{Incidence, survival, mortality, and prevalence}

\subsubsection{Incidence}

Prostate cancer (PCa) is the most common malignancy among men in Norway. From 2005 to 2009, 4,100 new cases were diagnosed annually, which represents $29 \%$ of all new annual male cancer cases (1). During the past two decades, there has been a marked increase in the incidence rate of PCa in Norway. From 1984 to 2008, the incidence rate/100,000 person-years (age adjusted to the world's standard population) more than doubled from 44.6 to 99.9 . The cumulative risk of developing PCa by the age of 75 years for Norwegian men is $12.4 \%$ (i.e., one in eight men) (1).

Internationally, there has also been a considerable increase in the incidence of $\mathrm{PCa}$ during recent decades, especially in developed countries. One important reason for this increase is the use of prostate-specific antigen (PSA) blood tests, which became available in 1980 in the United States and from the early 1990s in Norway (2). However, a minor increase in the incidence rate of PCa was observed in the period before the PSA test was introduced and was attributed mainly to the aging of the male population in general and the increased attention given to cancer diagnosed after surgical treatment for benign hyperplasia of the prostate $(2 ; 3)$.

\subsubsection{Survival}

The 5-year relative overall survival of PCa patients in Norway for the last reported period, 2005-2009, was $87 \%$ compared with $50 \%$ in the period 1970-1974 (1). This indicates that the prognosis for PCa in general is good. However, $20 \%$ of patients have metastatic disease at diagnosis, and the 5 -year relative overall survival for these patients is $31 \%$. For localized PCa, the 5 -year relative overall survival is currently $97 \%$. However, the long-term survival among patients diagnosed younger than age 50 years is poorer than for patients diagnosed at age 50-59 years. Reasons for this difference are that the younger age group has more aggressive tumors and that there is greater use of PSA screening in the older age group.

\subsubsection{Mortality rate}

PCa-specific mortality rates reflect the number of patients per 100,000 people who die each year from PCa. From a global perspective, $\mathrm{PCa}$ is the second most frequent cause of cancer death among men in the developed world. A slight increase in the number of deaths from PCa was observed from 1985 to the late 1990s in most countries, even in those countries or regions where PCa was rare. Since the late 1990s, a reduction in mortality has been observed globally and in Norway $(4 ; 5)$. The reasons for this reduction in mortality have been the subject of discussion, particularly in relation to whether the 
decrease is attributable to the increased use of PSA testing, leading to earlier diagnosis, and/or increased use of curative treatment (3). Conflicting data for PSA screening trials have been reported in North American and European studies. In one European trial, PCa mortality was reduced by $27 \%$ after 9 years and $44 \%$ after 14 years of follow-up after PSA screening (6-8). By contrast, data from a North American PSA screening trial showed no mortality benefit from PSA screening at 7-10 years' followup, and this was confirmed by recently published data for the 13-year follow-up (9). A Swedish substudy showed that, to prevent one death from PCa, 293 men needed to be screened and 12 treated for PCa compared with unscreened and untreated controls (8). These studies show that the differences, if any, in PCa mortality between screened and unscreened groups are small. However, at present, we cannot exclude the possibility that longer follow-up will change this conclusion, at least for some subgroups.

Screening for $\mathrm{PCa}$ is also controversial because of the costs, psychological effects, and uncertain long-term benefits to patients (10). For example, the European Association of Urology (EAU), Norwegian heath authorities, and Mayo Clinic guidelines all recommend that PSA tests should be performed only after discussion between the patient and his doctor. A recently published review concluded that PSA-based screening results in little or no reduction in PCa-specific mortality and is associated with harm related to subsequent evaluation and treatment, some of which may be unnecessary (11).

In Norway, $\mathrm{PCa}$ is second to lung cancer as the main cause of cancer-related death among men, and more men die from PCa than women die from breast cancer. The mortality rate peaked in the mid-1990s (see Figure 1.1) and has been declining since. It is not clear why Norway and the other Scandinavian countries have relatively high mortality rates from PCa. Apart from the high incidence, a possible explanation is differences in the coding of the causes of death between countries (12).

The National Program for Prostate Cancer in Norway (NPPC) was established in 2004, with the primary goal of improving survival, reducing mortality and quality of care for PCa patients through nationwide documentation of diagnosis, treatment, and progression of PCa. Importantly, the program recommends that all relevant data be recorded prospectively in a national database located within the Cancer Registry of Norway.

The increase in incidence and decrease in mortality over the past 15 years coupled with longer life expectancy for Norwegian men mean that the prevalence of $\mathrm{PCa}$ is increasing rapidly; at the end of 2008, 27,570 Norwegian men were living with a prior diagnosis of PCa.

\subsection{Risk factors for the development of PCa}

There are a number of risk factors for the development of PCa. The most importent is older age; by 80 years, $50 \%$ of all men have malignant cells in their prostate. In Norway, the mean general life expectancy for men is currently 79 years (13), and the median age at diagnosis is 70 years. Only $3.6 \%$ 
are diagnosed before the age of 55 years, and almost $70 \%$ of patients are older than 64 years at diagnosis. The number of new cancer cases among men in Norway is expected to increase by about $40 \%$ by 2030 because of population growth and the increased proportion of older people in the population (1).

Figure 1.1. Trends in age-standardized relative survival proportions, incidence, and mortality rate from Cancer in Norway, 2009 (1)

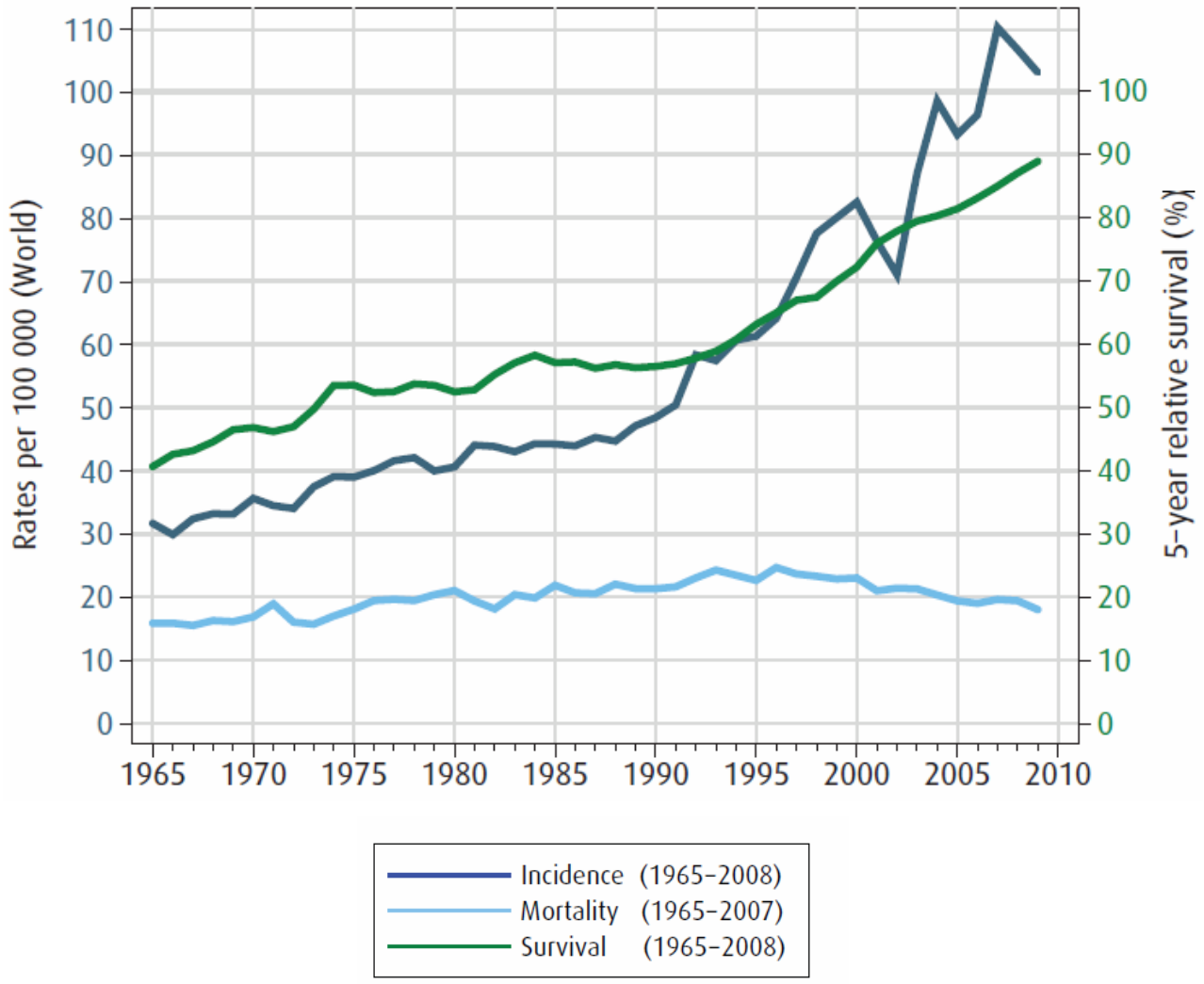

The incidence of PCa varies considerably between countries and world regions, and between ethnicities within a country. The highest annual incidence rate (185 per 100,000 men) is among African-American men, and the lowest incidence $(1.7$ per 100,000) is among Chinese men (3). However, when Japanese men (marry to Japan women) emigrate from Japan to Hawaii, their risk of PCa increases and approaches that of US-born men (14) within two generations, suggesting that environmental factors are more important than genetic factors.

Lifestyle factors including diet, alcohol consumption, sexual activity, exposure to ultraviolet radiation, and occupational exposure have all been reported as possible factors of etiological relevance (15). Nutritional factors considered as risk factors for the development of PCa include high total 
energy intake (reflected by body mass index) and intake of dietary fat and cooked meat, all of which increase the risk for PCa. Conversely, micronutrients and vitamins (carotenoids, retinoids, and vitamins $\mathrm{C}, \mathrm{D}$, and $\mathrm{E}$ ), fruit and vegetable intake, minerals (calcium and selenium), and phytoestrogens (isoflavonoids, flavonoids, and lignans) may all reduce the risk of $\mathrm{PCa}(16 ; 17)$.

Hereditary PCa occurs in a subgroup (about 9\%) of individuals with PCa and is identified by examination of the pedigree showing three or more affected relatives or at least two relatives who have developed early-onset disease before age 55 years (18). Patients with hereditary PCa have disease onset 6-7 years earlier, on average, than those with sporadic $\mathrm{PCa}$, but these two patient groups do not differ biologically (19). The gene mutations leading to the increased risk of developing hereditary PCa have not been identified at the molecular level. However, special interest has been directed toward inherited mutations of the tumor suppressor gene breast cancer types 1 and 2 (BRCA1 and 2) because male mutant carriers of BRCA2 have an increased risk of $\mathrm{PCa}$, whereas the risk of $\mathrm{PCa}$ in men with the BRCA1 mutation is not clear (20).

\subsection{Classification of $\mathrm{PCa}$}

In this thesis, the extent of disease is classified according to the sixth version of the tumor-nodemetastasis (TNM) system published in 2002 (21). Clinical staging (designated cTNM) defines the anatomical extent of a tumor based on clinical data before initiation of treatment. If the staging is based on radiological examination, it is designated rTNM. Pathological staging (designated pTNM) is based on examination by pathologists of tissues removed during prostatectomy (pT) or lymph node dissection $(\mathrm{pN})$. When considering curatively intended treatment for $\mathrm{PCa}$, an important distinction is made between localized (tumor localized to the prostate gland; T1-T2, N0, and M0) and locally advanced $\mathrm{PCa}$ (T3-T4, N0, and M0, where the tumor has grown through the capsule covering the prostate gland).

\subsubsection{T stage}

The extent of the primary tumor is assessed based on palpation during digital rectal examination (DRE), where the distinction between intracapsular (T1-T2) and extracapsular (T3-T4) PCa has a significant impact on treatment decisions and prognosis. Several studies have shown that DRE often underestimates tumor extension (22;23).

The clinical examination can be supported by various imaging procedures. The most commonly used method is transrectal ultrasound (TRUS) examination. However, only $60 \%$ of tumors are visible with TRUS; the remaining tumors are not distinguishable from normal tissue because of their echogenicity. In a large multi-institutional study, TRUS was no more accurate than DRE at predicting organ-confined PCa (24;25). Furthermore, neither conventional magnetic resonance 
imaging (MRI) nor positron emission tomography (PET) accurately predicts extracapsular extension of $\mathrm{PCa}(26 ; 27)$.

Table 1.1. Tumor-node-metastasis (TNM) classification of PCa 2002 (28)

\section{$\underline{T-P r i m a r y ~ t u m o r}$}

TX Primary tumor cannot be assessed

T0 No evidence of primary tumor

T1 Clinically undetected tumor not palpable or visible by imaging

T1a Tumor incidental histological finding in $5 \%$ or less of tissue resected

T1b Tumor incidental histological finding in more than $5 \%$ of tissue resected

T1c Tumor identified by needle biopsy (e.g., because of elevated prostate-specific antigen level)

T2 Tumor confined within the prostate

T2a Tumor involves one-half of one lobe or less

T2b Tumor involves more than half of one lobe, but not both lobes

T2c Tumor involves both lobes

T3 Tumor extends through the prostatic capsule ${ }^{2}$

T3a Extracapsular extension (unilateral or bilateral)

T3b Tumor invades seminal vesicle(s)

T4 Tumor is fixed or invades adjacent structures other than seminal vesicles: bladder neck, external sphincter, rectum, levator muscles, or pelvic wall

\section{N-Regional lymph nodes ${ }^{3}$}

NX Regional lymph nodes cannot be assessed

N0 No regional lymph node metastasis

N1 Regional lymph node metastasis

\section{$\underline{\text { M - Distant metastasis }}{ }^{4}$}

MX Distant metastasis cannot be assessed

M0 No distant metastasis

M1 Distant metastasis

M1a Nonregional lymph node(s)

M1b Bone(s)

M1c Other site(s)

\footnotetext{
${ }^{1}$ Tumor found in one or both lobes by needle biopsy, but not palpable or visible by imaging, is classified as T1c.

${ }^{2}$ Invasion into the prostatic apex or into (but not beyond) the prostate capsule is not classified as T3, but as T2.

${ }^{3}$ Metastasis no larger than $0.2 \mathrm{~cm}$ can be designated $\mathrm{pN} 1 \mathrm{mi}$.

${ }^{4}$ When more than one site of metastasis is present, the most advanced category should be used.
} 
The recently updated EAU recommendation states that MRI should not be used in routine clinical assessment of the T stage (29). The addition of dynamic contrast-enhanced MRI can be helpful in difficult cases. The addition of magnetic resonance spectroscopic imaging to MRI also increases the accuracy and decreases interobserver variability in the evaluation of extracapsular extension of PCa (30).

\subsubsection{N stage}

According to the EAU, $\mathrm{N}$ staging should be performed only when the findings will influence a treatment decision. The gold standard for assessing regional lymph node involvement in PCa is pelvic lymphadenectomy performed using an open or laparoscopic technique. Patients with tumor stage T2 or lower, with a PSA level $<20 \mu \mathrm{g} / \mathrm{L}$ and Gleason score $\leq 6$, have a $<10 \%$ likelihood of having lymph node metastases and can therefore be spared pelvic lymphadenectomy (31). In the current literature, computed tomography (CT) and MRI perform equally well for the detection of pelvic lymph node metastases (32).

\subsubsection{M category}

Although PCa metastasizes mainly to bone, metastases can be found in any organ. According to the EAU guidelines, bone metastases are best assessed by a technetium bone scan. This type of scan is not indicated in asymptomatic patients if the serum PSA level is $<20 \mu \mathrm{g} / \mathrm{L}$ and in the presence of well- or moderately differentiated tumors (Gleason score $\leq 6$ ). Because the scope of this thesis is nonmetastatic and curable $\mathrm{PCa}$, the issue of metastatic disease is not discussed further.

\subsection{Histopathology}

The aggressiveness of the malignancy can be identified by a pathologist's examination of the microscopic pattern of the prostate cancer cells. According to the EAU guidelines (31), in patients with a glandular volume of $30-40 \mathrm{~mL}$, at least eight biopsies should be taken. The Gleason score is the most commonly used system for grading adenocarcinomas of the prostate, and the system has been recommended by the World Health Organization since 1993 (33). The Gleason score is the sum of the two most common patterns (grades 1-5) of tumor growth found. The Gleason sum score ranges between 2 and 10, with 2 being the least aggressive growth pattern and 10 the most aggressive. The pathologist assigns a primary grade to the most common tumor pattern and a secondary grade to the next most common tumor pattern, and these grades are added. A Norwegian national study by Kvåle et al. (34) reported the following distribution of Gleason scores: score 2-4, 4.5\%; score 5-6, 65.5\%; score 7, 25.7\%; and score 8-10, 4.3\%.

Preoperative needle biopsy specimens often yield lower Gleason scores than postoperative examination of the prostatectomy specimen. A review of 3,789 cases of PCa from the United States 
showed that the Gleason score was undergraded in $42 \%$ of cases and overgraded in $15 \%$ of cases, compared with examination of the whole-gland specimen (35). Bill-Axelson et al. (36) found similar data, with $48 \%$ of biopsy samples undergraded compared with whole-gland specimen examination. A Norwegian study by Kvaale et al. (34) of 1,116 patients showed the same trend for undergrading of needle biopsy material. The biopsy-based Gleason score was undergraded (38\%) more often than overgraded (9\%) compared with postoperative examination (34). The Norwegian Radium Hospital $(\mathrm{NRH})$ introduced the Gleason score as the standard classification in 2000 (37), and the Gleason score with the latest update is currently the standard classification for PCa pathology in Norway.

\subsection{Biomarkers}

\subsubsection{PSA}

PSA is a kallikrein-like serine protease (glycoprotein) produced almost exclusively by the epithelial cells of the prostate. The function of PSA is liquefaction of the ejaculate, which allows spermatozoa to swim freely (38). For practical purposes, PSA is prostate specific but not cancer specific. Thus, serum PSA level may also be elevated in the presence of benign prostatic hypertrophy, prostatitis, and other nonmalignant conditions. PSA is currently one of the most important biomarkers in oncology and is used for screening for and diagnosis and follow-up of PCa. Measurement of serum PSA level is considered the most effective test currently available for the early detection of $\mathrm{PCa}$, although the effectiveness has been challenged because the positive predictive value of the test is only about $35 \%$ (6;6;39). The PSA level shows a continuous pattern; that is, the higher the level, the more likely the existence of $\mathrm{PCa}$, which means that there is no universally accepted cutoff level for serum PSA that excludes $\mathrm{PCa}(40)$.

\subsubsection{PSA dynamics (doubling time and velocity)}

PSA doubling time (PSADT) can be used in the posttreatment setting. According to D'Amico et al. (41), the PSADT is positively associated with posttreatment PCa-specific survival and is considered a surrogate endpoint for PCa-specific survival in men with biochemical recurrence. However, the role of the PSADT in predicting tumor biology before treatment is unclear, especially among men with earlystage PCa (41-43). In some studies, the PSA velocity (rate of change of PSA level) is advocated as a predictor of PCa development (44;45), but currently PSA velocity is not a standard form of assessment for patients, according to the 2012 EAU guidelines (31) or the 2009 Norwegian guidelines (46).

\subsubsection{Follow-up}

According to the 2012 EAU guidelines (31), regular measurement of PSA level is mandatory in the follow-up of patients after curatively intended treatment of PCa. However, the level of PSA used to 
define treatment failure differs between radical prostatectomy (RP) and radiotherapy (RAD). According to international consensus, biochemical PCa recurrence after RP is defined by two consecutive measurements of PSA level $\geq 0.2 \mu \mathrm{g} / \mathrm{L}$ (47). The PSA patterns following RAD are more difficult to interpret. A 2006 consensus statement between the American Society for Therapeutic Radiology and Oncology (ASTRO) and the Radiation Therapy Oncology Group (RTOG) gave a common definition of radiation therapy failure based on PSA level. The definition stated that treatment failure with or without hormone therapy is an increase of $2 \mu \mathrm{g} / \mathrm{L}$ above the posttreatment PSA nadir (the lowest PSA level measured after RAD) (48). This is also known as the Phoenix definition (or consensus), after the city where the consensus was reached; this definition is now incorporated in both the EAU (31) and Norwegian (46) guidelines.

\subsection{Risk stratification of PCa}

PSA level, Gleason score, and tumor stage are all independent prognostic factors for the outcome of $\mathrm{PCa}(49 ; 50)$. Using all three variables, D'Amico et al. developed a system of risk stratification that is significantly associated with PCa recurrence and PCa-specific mortality (50). The D'Amico classification identifies three risk levels and allows for pretreatment grouping of PCa patients: low-risk patients (stage T1c, T2a and PSA level $\leq 10 \mu \mathrm{g} / \mathrm{L}$ and Gleason score $\leq 6$ ); intermediate-risk patients (stage T2b or Gleason score of 7 or PSA level $>10$ and $\leq 20 \mu \mathrm{g} / \mathrm{L}$ ), and high-risk patients (any stage $\geq$ T2c or PSA level $>20 \mu \mathrm{g} / \mathrm{L}$ or Gleason score $\geq 8$ ).

Optimal treatment of nonmetastatic PCa requires assessment of pretreatment risk categories because the treatment recommendations vary accordingly. Slightly modified D'Amico criteria are included in today's treatment guideline recommendations.

\subsection{Treatment modalities}

Local treatment of PCa offers several options. These modalities are active surveillance (AS), RP, and conformal external beam radiotherapy (EBRT) (which can be combined with high-dose brachytherapy) with or without hormone therapy (31). Another option is to select watchful waiting (WW) for a subgroup of patients. The availability of several treatment options gives rise to at least two challenges: (1) the provision of adequate information about treatment alternatives to the patient by his physician and (2) the risk of suboptimal treatment because of the variations in tumor biology and aggressiveness. Therefore, the choice of treatment after the appropriate assessment of tumor extension and aggressiveness must be based on individual preferences and on the recommendations of a multidisciplinary team of clinicians after consideration of the following factors:

- TNM classification

- Gleason score defined by a sufficient number of prostate core biopsies $(\geq 8)$

- Baseline PSA level 
- D'Amico risk group

- Age of the patient

- Comorbidities, life expectancy, and quality of life (QoL)

- Expected side effects of therapy

- Patient's wishes.

\subsection{1. $A S$}

According to National Comprehensive Cancer Network ${ }^{\circledR}$ (NCCN) guidelines (51), AS (also referred to as observation or expectant management) is defined as active monitoring of the course of the disease with the intention of intervening with curative treatment if the tumor progresses. AS was introduced with the aim of reducing the proportion of overtreatment in patients with clinically confined low-risk $\mathrm{PCa}$ without relinquishing the opportunity for radical treatment, as was the case with the WW strategy (see below). A recently published prospective study (52) offers the most conclusive evidence that AS may be the preferred option for most older men with a very low-grade PCa (cT1c, PSA $<0.15 \mu \mathrm{g} / \mathrm{L}$, Gleason score $\leq 6, \leq 2$ core biopsies with cancer, and $\leq 50 \%$ cancer involvement of any core biopsies). An argument against using AS is the need for regular biopsies, which carries a slightly increased risk of multiresistant infections in the pelvic area, and the psychological burden related to the patient living with an untreated cancer. Except for some types of lymphoma, $\mathrm{PCa}$ is the only major cancer type in which a group of patients (10-20\%) may be candidates for AS rather than for active treatment for localized disease; this fact clearly demonstrates the slow progression of low-risk PCa in general.

\subsection{2. $W W$}

The term WW was coined in the pre-PSA screening era before 1990. Also known as deferred treatment, WW refers to the conservative management of PCa until the development of local or systemic progression of the disease, at which point the patient would be treated palliatively with either transurethral resection of the prostate or other procedures for urinary tract obstruction, and with hormones or RAD for the palliation of the metastatic lesions. The rationale of WW is that PCa usually progresses slowly and is often diagnosed in older men who have a high incidence of comorbidity and competitive mortality risk factors (53). According to the 2012 EAU guidelines (31), WW should be considered an option for patients with localized PCa and with a limited life expectancy (i.e., older patients with less aggressive PCa and poor health because of comorbidities); WW is not considered a curative treatment option.

\subsubsection{Hormone therapy}

The epithelial cells of the prostate gland are dependent on androgens for cellular growth, and depletion of androgens will therefore inhibit cell growth in both normal and malignant prostate cells. After 
surgical castration, only the adrenal glands produce a very low amount of androgens, and therefore castration is still considered the gold standard of androgen-deprivation therapy (ADT) against which other treatment alternatives are compared. For patients with localized $\mathrm{PCa}$, there are two ways to undertake medical ADT: using a luteinizing hormone-releasing hormone (LHRH) agonist, or antiandrogen therapy. LHRH agonists mimic normal LHRH and occupy the receptors of the pituitary gland necessary for normal LHRH signals. The hypogonadal effect (i.e., decreased Folliclestimulating hormone (FSH) and Luteinizing hormone ( $\mathrm{LH}$ ) production) decreases the testosterone production in the testicles, and the level of testosterone declines by $90-95 \%$ to the castration level. Anti-androgens are classified as steroidal or nonsteroidal. Steroidal anti-androgens counteract androgens and affect secondary sex characteristics. They directly affect gene expression and, because of their fat-soluble nature, they are able to diffuse through the plasma membrane's phospholipid bilayer and prevent the intracellular binding of testosterone and dihydrotestosterone to the androgen receptor. By contrast, nonsteroidal anti-androgens or "pure" anti-androgens counteract androgens and have no steroidal effects. They act by binding to the androgen receptor and preventing the activation and subsequent upregulation of androgen-responsive genes by androgenic hormones. There has been a trend toward an increasing use of hormone treatment in younger men in the early stages of PCa as adjuvant to local treatment.

In the Scandinavian Prostate Cancer Group (SPCG)-7 study for high-risk PCa, the addition of RAD to endocrine treatment halved the 10-year disease-specific mortality. (54;55). Compared with RAD alone for locally advanced or localized high-risk PCa, adjuvant castration-based hormone therapy improves clinical outcomes to a significant extent (55-58). In a European Organisation for Research and Treatment of Cancer (EORTC) study by Bolla et al., the 10-year clinical disease-free survival was $23 \%$ for RAD alone compared with $48 \%$ in the combined treatment group (56). The duration of ADT varies between studies. In the trial by Bolla et al., the patients were treated with ADT for 3 years, whereas the patients in the SPCG-7 study were treated with bicalutamide until PCa progression or death (55).

The necessary duration of ADT treatment is still unclear, but among men with localized $\mathrm{PCa}$ undergoing conventional-dose radiation therapy, at least 6 months of hormone therapy appears necessary to prolong survival among patients with high-risk disease (59).

\subsection{4. $R P$}

The curative surgical treatment for PCa comprises RP, which involves the removal of the whole prostate gland and resection of both seminal vesicles together with sufficient surrounding tissue to obtain microscopically tumor-free margins. The 2012 EAU guidelines state that, in men with localized $\mathrm{PCa}$ and a life expectancy $>10$ years, the goal of RP is eradication of disease while preserving urinary continence and erectile function whenever possible (60). RP is a recommendable treatment option for 
selected patients (life expectancy $>10$ years) with localized PCa (stage $\leq \mathrm{T} 2$ ) because RP will remove all tumor tissue. For patients in the D'Amico intermediate- and high-risk categories, RP should be accompanied by bilateral pelvic lymph node dissection.

In a randomized study, SPCG-4, published by Bill-Axelson et al. (36;61), RP is the only treatment for localized PCa with demonstrated PCa-specific survival benefit compared with WW. However, the significant survival benefit (40\%) was observed only in patients younger than 65 years at diagnosis. The SPCG-4 study was undertaken in the 1980s before PSA era, and the patient sample of that study is not completely comparable to today's patient populations.

Patients with high-risk PCa (stage $\geq \mathrm{cT} 2 \mathrm{c}$ or Gleason score $8-10$ or PSA $>20 \mu \mathrm{g} / \mathrm{L}$ ) must be informed about the likelihood of a multimodal treatment approach. In patients with adverse tumor characteristics (positive surgical margins, extracapsular extension, and seminal vesicle invasion), adjuvant RAD can often be used after recovery from surgery. A study by Johnstone et al. (62) showed that patients $(\mathrm{N}=72)$ who had RP for cT4 disease had survival rates similar to men who received RAD plus ADT. Higher rates of cancer-free surgical margins for surgeons with high-volume experience suggest that experience is an important predictor of the oncological outcome (63).

The two most common procedures for RP are the standard open radical retropubic prostatectomy (ORRP) and robot-assisted laparoscopic prostatectomy (RALP). The latter procedure uses a specially designed robotic system (da Vinci system ${ }^{\circledR}$ ) (64). The first RALP was performed in 2000 by Binder and Kramer (65), and in Norway the method was introduced at NRH in December 2004. So far, no significant differences in the oncological outcomes after ORRP versus RALP have been reported, but perioperative complications such as blood loss, perioperative blood transfusions, and the length of the hospital stay are more favorable for patients having RALP compared with ORRP (66-68). In addition, because the procedure by RALP is less traumatic, more patients with comorbidity can now be offered radical surgery than in the past.

The goal of nerve-sparing surgery is to reduce the risk of postoperative erectile dysfunction. The nerve sparing can be graded as none, unilateral, or bilateral (69), although this categorization has several weaknesses as a predictor of erectile function and has yielded inconsistent data between studies $(69 ; 70)$. Several researchers have suggested recently that nerve sparing is not absolute but rather that the neurovascular bundles can sustain varying degrees of damage during surgery $(71 ; 72)$. A more detailed definition of nerve sparing has been provided recently by Moskovic et al. (73) (table 1.2) and Levinson et al. (71). 
Table 1.2. Nerve-sparing score grading system according to Moskovic et al. (73)

\begin{tabular}{|l|l|}
\hline Criterion & Score \\
\hline Complete preservation & 1 \\
Near-complete preservation & 2 \\
Partial resection & 3 \\
Complete resection & 4 \\
\hline
\end{tabular}

In 2009, 1,177 patients were treated with RP for localized/locally advanced PCa in Norway, and the RALP technique was used for about $55 \%$ of them (personal information from colleague Andreas Steinsvik, MD).

\subsubsection{RAD}

Several RAD techniques are applied for the treatment of PCa. According to the 2012 EAU guidelines (31), three-dimensional conformal radiotherapy (3D-CRT) is the current gold standard for RAD. Since 2000, intensity-modulated radiotherapy (IMRT), an optimized form of 3D-CRT, has been introduced gradually in leading cancer centers, particularly if the pelvic lymph nodes are to be irradiated together with the prostate. Several randomized phase III trials have been conducted in patients with localized and locally advanced PCa by the RTOG (United States), the SPCG, and EORTC (74-76). The findings have established the total doses and current indications for the combination of external irradiation and ADT, as described previously $(55 ; 56 ; 77)$.

\subsubsection{Technical aspects of RAD}

There is a well-described dose-response relationship for RAD for the different risk groups of PCa (78$80)$, including low-risk groups (81-83), and intermediate- and high-risk groups $(57 ; 80 ; 84 ; 85)$. In daily practice, a minimum radiation dose of $\geq 74$ Gy is recommended (74) for low-risk patients (Gy $=$ Gray, the unit for the absorbed radiation dose).

Three local techniques are available to escalate the radiation dose with acceptable side effects for higher-risk patients: IMRT in combination with image-guided radiotherapy (IGRT), high-dose-rate brachytherapy, and proton therapy. IMRT in combination with IGRT might allow dose escalation to $>80$ Gy with acceptable toxicity (86). IGRT uses a standard CT scan coinstalled with the linear accelerator, and gold seeds are implanted in the prostate gland to serve as landmarks for onsite positioning of the patient. With precise positioning, margins can be reduced (i.e., on the anterior wall of the rectum), which reduces adverse effects (AEs). When one or few pelvic lymph node metastases are suspected, several retrospective studies have shown that combination therapy including irradiation of the pelvic lymph nodes and ADT improves disease-free interval and overall survival compared with ADT alone in this high-risk group of patients $(84 ; 87)$. However, these data have not been confirmed in 
prospective trials. According to Lawton et al. $(88 ; 89)$, a lower limit of $15 \%$ risk of lymph node metastases suggests that there should be irradiation to the pelvic field, including the pelvic lymph nodes and the prostate ( $\sim 50 \mathrm{~Gy})$, followed by a boost to the prostate. A nomogram is used to calculate pelvic lymph node disease risk (90).

\subsubsection{2. $H D R-B T$}

HDR-BT (high radiation dose per time unit) is a radiation method in which threadlike radiation sources are inserted temporarily into the prostate. The source is introduced through hollow steel needles that are inserted through the perineum and into the prostate. Depending on the size of the prostate, 12-18 needles are inserted under ultrasound guidance. At NRH, iridium sources $\left({ }^{192} \mathrm{Ir}\right)$ are inserted through the needles. A high radiation dose ( $\geq 10 \mathrm{~Gy})$ is emitted quickly into the core of the gland. The advantage of brachytherapy is the limited dose to the surrounding organs, especially the anterior wall of the rectum, and thus reduced side effects in this organ. The urethra is another organ at high risk of toxicity, and the maximum dose to the urethra should be $<12 \mathrm{~Gy}$. The entire procedure takes $2-3$ hours and should be repeated after 2 weeks (91), followed by EBRT.

\subsubsection{Low-dose-rate brachytherapy (LDR-BT)}

LDR-BT or permanent interstitial brachytherapy is a technique of short-distance radiotherapy using low-energy radioactive sources that are placed in or near the tumor in the prostate and that emit radiation at a rate of $<2$ Gy per hour (92). LDR-BT is recommended as an alternative to surgery for men with low-risk localized PCa. The radioactive seeds are implanted permanently into the prostate tissue through a transperineal technique guided by ultrasound. In contrast to most European countries, LDR-BT is currently not available in Norway. According to the literature, LDR-BT leads to a similar biochemical (PSA) recurrence-free survival as RP at 5 years for low-risk patients (93). 
Figure 1.2. Conformal radiotherapy of PCa
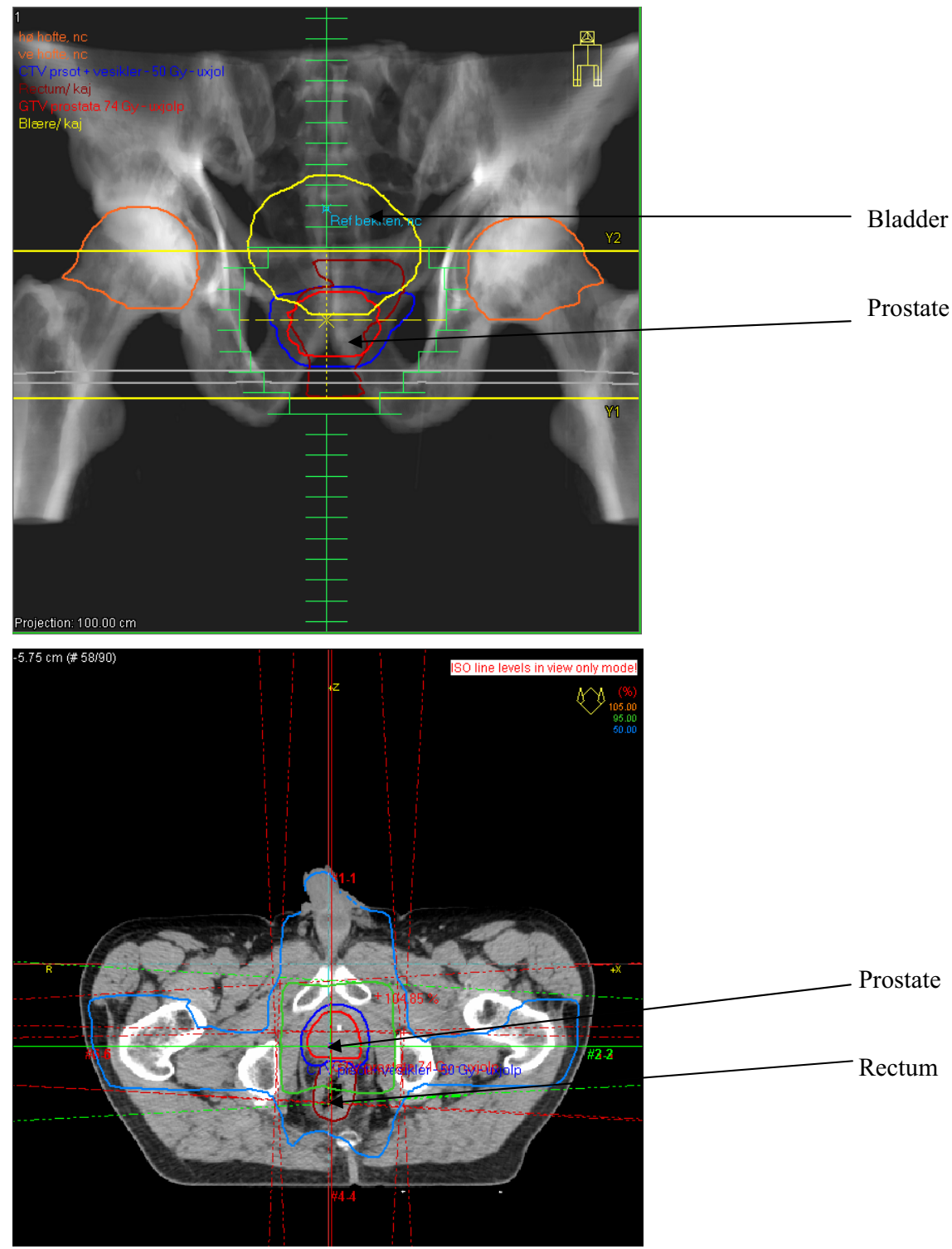

\subsubsection{RAD after $R P$}

Patients in whom the surgical prostate specimen show extension through the capsule (pT3) or who have malignant cells in the surgical margins may benefit from adjuvant RAD, even in the presence of PSA $<0.2 \mu \mathrm{g} / \mathrm{L}$. Salvage RAD is defined as RAD given to a prostatectomized patient with a demonstrated local recurrence or increase of PSA level without evidence of metastasis. Three large 
randomized controlled studies of adjuvant RAD have been published (94-96), and all showed a survival benefit with adjuvant RAD or salvage RAD of at least $15 \%$ at 5 years in terms of biochemical recurrence-free survival. The radiation doses used in these trials ranged from 60 to $64 \mathrm{~Gy}$, which are less than the 66 Gy currently recommended for adjuvant and salvage RAD. Thus, as in dose-escalation studies of primary radiation for $\mathrm{PCa}$, an increased dose in the salvage setting may improve recurrencefree survival with acceptable local toxicity; accordingly, doses up to 70 Gy show better biochemical recurrence-free survival than lower doses $(97 ; 98)$. Because only one of the patients studied in this thesis fulfills the criteria for adjuvant or salvage RAD, and this issue is therefore not discussed further.

\subsection{AEs}

All PCa treatment alternatives except AS and WW have AEs, which affect patients to a variable degree. An $\mathrm{AE}$ is defined as a harmful and undesired effect resulting from any active medical intervention such as surgery, RAD, or medication. AEs are sometimes referred to as iatrogenic because they are generated by a treatment initiated by a physician.

\subsubsection{Common AEs after treatment of PCa}

Curative treatment of $\mathrm{PCa}$ is frequently associated with several AEs, which can be localized and/or general. The most frequent AEs of PCa treatment affect sexual, urinary, and bowel functions ("typical AEs").

\subsubsection{Sexual dysfunction}

Sexual dysfunction is the most common AE after curative treatment of PCa (99). According to the 2012 EAU guidelines, several studies of men who have satisfactory pretreatment erectile function indicate that $29-100 \%$ develop erectile dysfunction after surgery because of damage to the neurovascular bundle (100-102).

In a recently published paper based on the SPCG-4 study with a median follow-up of more than 12 years, more men treated with RP reported low intercourse frequency compared with men in the WW group (103), although the relative risk was not significant (age-adjusted relative risk 0.69 $(0.47-1.03))$. Nerve-sparing surgery had not been used in these men's operations.

Erectile dysfunction may also be caused by RAD because the neurovascular bundle, internal pudendal artery, and proximal penile structure are exposed to radiation, leading to eventual development of slow tissue destruction, fibrosis, and narrowing of the arterial diameters (104). In contrast to the dysfunction that occurs shortly after surgery, the prevalence of erectile dysfunction after RAD increases gradually for the first 5 years (105). In a study with few participants $(\mathrm{N}=29)$ who were treated between 1986 and 1989, Fransson et al. (106) reported that sexual activity 15 years after RAD was very low compared with 34 age-matched controls (38\% compared with $78 \%$ ). 
Sexuality is a complex function in which mental state also plays an important role. Studies have shown that fatigue and depression, which are common posttreatment AEs, decrease the sexual drive. In considering sexual AEs, it is also important to consider the pretreatment situation. For instance, both older age (107) and comorbidity (108) negatively affect erectile function.

\subsubsection{Urinary dysfunction}

Both RP and RAD affect urinary function but in different ways. Subsequent to RAD, acute inflammatory prostatitis and/or cystitis may give rise to symptoms such as increased frequency, urgency, incontinence, retention, and dysuria. These symptoms are often transitory, but may be followed by long-term AEs such as bladder fibrosis, strictures, sphincter damage, and chronic irritative urethritis and/or cystitis. The most common urinary AEs after RAD are increased frequency and urgency (109-111). Some studies indicate that HDR-BT results in less urinary dysfunction than EBRT $(112 ; 113)$.

Patients with localized PCa who had RP tend to experience urinary leakage more often than men treated with RAD (114). According to the 2012 EAU guidelines (31), the most common AE after surgery is urinary leakage ( $8 \%$ ) because of sphincter damage (115). In men undergoing RP, the rates of postoperative and late urinary complications are significantly reduced if the procedure is performed in a high-volume hospital and by surgeons who perform a large number of such operations $(100 ; 101 ; 116)$. The problem in comparing studies is that the definition of leakage varies greatly between studies and is categorized most often as the number of pads used daily.

\subsubsection{Bowel dysfunction}

Bowel function is affected primarily by RAD because the anterior wall of the rectum is included in the radiation field of the prostate. Bowel dysfunction can often be divided into acute and chronic phases. Acute AEs are caused by epithelial damage, which may result in diarrhea and painful bowel movements. Chronic radiation effects to the rectum include fibrosis and vascular damage, which may lead to symptoms such as increased flatulence, rectal bleeding, diarrhea, painful bowel movements, rectal urgency, increased frequency, and fecal leakage (117). The symptoms are more severe if the lymph nodes also are irradiated, and the risk of late bowel AEs increases with higher radiation doses. According Wahlgren et al., HDR-BT causes less severe bowel dysfunction (118). The introduction of IGRT has led to reduced doses to the anterior wall of the rectum, and the degree of bowel dysfunction is expected to diminish accordingly (119). 


\subsubsection{Other AEs}

\subsubsection{Fatigue}

Fatigue is a common symptom of cancer and cancer treatment. Fatigue is a multidimensional symptom defined by the European Association for Palliative Care as "the subjective feeling of tiredness, weakness or lack of energy not improving after rest" (120). If the fatigue lasts for more than 6 months, it is referred to as chronic fatigue (CF). The prevalence of CF in the general Norwegian male population is about $10 \%$ (121), and the prevalence of CF following RP and RAD without ADT in PCa patients has been reported as $13-26 \%$ (122). The higher rate of CF for RAD compared with surgery can be explained by the inflammation-stimulating effect of RAD, which causes the release of proinflammatory cytokines that may play a role in the development of CF (123-126). Another contributing factor may be that RAD patients often have more comorbidities than RP patients before treatment.

\subsubsection{Endocrine AEs}

Endocrine effects from adjuvant ADT add to the total load of AEs (127) because long-term use can lead to osteoporosis, weight gain, fatigue, depression, and gynecomastia. ADT can also have mental effects including depression (128) and impaired vitality (129). A large population-based study in Sweden found increased relative risks of nonfatal and fatal cardiovascular disease among all men with PCa, especially those treated with ADT (130). According to Poppel et al. (131), long-term use of LHRH antagonists is associated with increased risk of diabetes and cardiovascular events. However, a recent meta-analysis of randomized trials by Nguyen et al. (132) showed that ADT reduces PCaspecific mortality and all-cause mortality without increasing the risk of cardiovascular death.

\subsubsection{Secondary malignancies}

RAD is linked to the late occurrence of secondary malignancies both in the pelvis and outside the targeted area because of low-dose radiation scatter. Secondary malignancies following RAD include predominantly bladder cancer, and colon cancer to a lesser extent (133-135). However, secondary cancers in general are rare, especially after RAD for PCa, because of the advanced age of most patients. The increased risk of secondary malignancies for RAD patients is $0.16 \%$ after 10 years (136).

\subsubsection{AEs by treatment modality}

No randomized studies have directly compared the prevalence rate of AEs from RP with those from RAD. However, available data indicate a higher risk of erectile dysfunction and urinary incontinence following RP and a higher risk of irritative urinary symptoms and bowel dysfunction after RAD (137139). For short-term severe AEs, LDR-BT produced significantly less urinary incontinence than RP, 
but RP caused more urinary irritation than LDR-BT (93). In some studies, HDR-BT was associated with fewer rectal AEs and more urinary AEs compared with EBRT (140); however, Joseph et al. (141) found no difference between the two treatment modalities.

Table 1.3. Adverse effects in relation to treatment modalities

\begin{tabular}{|l|l|l|l|}
\hline AE & RAD & RP & ADT \\
\hline Reduced bowel function & Moderate & & \\
\hline Reduced urinary function & Moderate & Moderate & \\
\hline Reduced erectile function & Limited & Much & Much \\
\hline Fatigue & Moderate & Little & Much \\
\hline Secondary malignancies & Limited & & $\begin{array}{l}\text { Limited }^{1} \\
\text { Limited }^{1} \\
\text { Limited } \\
\text { Diabetes } \\
\text { Cardiovascular disease } \\
\text { Mental adverse effect }\end{array}$ \\
\hline
\end{tabular}

${ }^{1}$ Nguyen et al. showed no correlation (132).

\subsection{QoL}

A general definition of QoL has been provided by the World Health Organization (1992).

QoL is defined as an individual's perception of his position in life in the context of the culture and value system in which he lives and in relation to his goals, expectations, standards, and concerns. It is broad-ranging concept affected in a complex way by the person's physical health, psychological state, level of independence, social relationships, and their relationship to salient features of their environment.

A more narrow QoL concept concerns health: "Health-related quality of life includes social, mental and physical dimensions, and represents the parts of life that are related to the health of an individual" (142). In medical studies, QoL is often defined as a multidimensional concept that includes a number of physical and mental dimensions.

Most importantly, QoL is a subjective assessment that involves the patient's own perceptions of his or her situation, satisfaction, and ability to function in life. QoL is therefore measured by selfrating using questionnaires, and patients are often asked to rate their symptoms before and after treatment, together with eventual AEs. Different instruments have been developed for this purpose. The distinction between generic and disease-specific QoL instruments is important. Generic instruments such as the Short Form-36 (SF-36) and Short Form-12 (SF-12) are not concerned with 
disease-specific health problems but include various general functions and symptoms. The EORTC Quality of Life Questionnaire Core (EORTC QLQ-C30), for example, is applicable to all cancer types (143). By contrast, disease-specific instruments include specific features of various diseases. For patients with PCa, health-related QoL may be separated into three components: general, cancer specific, and disease specific.

\subsubsection{Instruments to measure disease-specific QoL}

Previously, AEs were evaluated only by doctors, but over the past two decades there has been growing recognition of the value of incorporating patients' concerns. Using questionnaires, patients are asked to rate their symptoms and functions before and after treatment, together with their AEs. Various instruments have been developed for this purpose. Studies of the correspondence between doctors' and patients' evaluation of AEs after treatment for PCa have shown variable degrees of concordance (144). However, a general finding is that doctors in clinical routine work often underreport their patients' AEs and dysfunctions.

Several self-rating instruments have been developed to record AEs reported by PCa patients. The EORTC Prostate Cancer Module (PR-25) and the University of California at Los Angeles (UCLA) Prostate Composite Index (PCI) are examples. The EORTC QLQ-PR25, developed by the EORTC Genito-Urinary Tract Cancer Cooperative Group, is a 25 -item questionnaire designed for use in patients with localized and metastatic PCa. It was developed within the framework of the EORTC Quality of Life Group according to rigorous guidelines for module development (145). Published by Litwin in 1995, the UCLA-PCI is used widely internationally as a systematic instrument for monitoring AEs after treatment for PCa (146). The UCLA-PCI instrument contains 37 items addressing five modules. The urinary tract domain is covered by six questions, bowel domain by five, sexual domain by nine, somatic morbidity by 14 , and demography by three. The psychometric characteristics of the UCLA-PCI were developed and tested by Litwin et al. (147).

In UCLA-PCI Litwin et al. (146) emphasized that the recording of AEs in PCa patients must separate function and bother as two independent domains. Bother can be defined as the degree of distress or annoyance caused by any AEs. The distinction between these two concepts is important. For example, some men with significant sexual dysfunction are minimally bothered, whereas others with only mild dysfunction may feel miserable. Therefore, although function and bother caused by erectile dysfunction often are linked together, they represent different domains and must be measured separately (148). The responsiveness for change of the UCLA-PCI was documented in the short-term recovery period (12 months after treatment) and over the long term (12-24 months) across almost all QoL domains.

The questionnaire has been developed further with the publication in 2000 of the Expanded Prostate Cancer Index Composite (EPIC) with 50 items (149). The assessment of sexual, urinary, and 
bowel functions and bother as treatment-related AEs is continued in the EPIC-50, although two shorter versions of EPIC have been published recently: EPIC-26 with 26 items (150) and EPIC-clinical practice (CP) with 16 items (151). EPIC-CP is practical for use in both community and academic settings. Due to fewer items the patients complete the EPIC-CP faster, but the reliability and validity require further examination.

\subsubsection{New statistical tools to evaluate treatment options}

After a diagnosis of $\mathrm{PCa}$, the patient often wants to know what type of AEs he can expect after curative treatment, the expected duration, and the chances of regaining pretreatment function. The patient is also interested in knowing whether and to what degree AEs will affect the domains of QoL. Several studies have compared and described AEs after the various treatment modalities for PCa $(137 ; 138 ; 152)$. Most studies have compared and described these effects in patients treated with either surgery (often mixed groups of patients treated with RALP or ORRP) or RAD (often mixed groups with or without ADT).

Two new statistical methods for prospective assessment of AEs after treatment have been introduced recently: proportions of patients regaining a certain percentage of their baseline function score (PBS) $(113 ; 152)$ and the generalized estimating equation (GEE).

The PBS was first described by Litwin et al. (113), when Malcom et al (152), and the models were created based on the occurrence of a patient's return to baseline score at follow-up time points. A patient is considered to have returned to baselineat a time point (for example 6 months) if his domain score is at least $90 \%$ of his baseline score.

The GEE is a method for analyzing associations, with final outcomes adjusted for baseline scores and time-dependent covariates $(137 ; 138)$. The GEE is often used to analyze longitudinal and other correlated response data, particularly if the responses outcomes are binary. A strength of the GEE method is that it is not sensitive to missing data in the analyses. The GEE represents a methodological improvement over paired sample $t$ tests and repeated-measures analysis of variance because it adjusts for baseline levels and previous times for typical dysfunctions (153). Another advantage of the GEE is that if the total number of observations for each individual is random (even if these are not independent of the values for the observed responses in that individual) (154).

\subsection{Guidelines}

Guidelines in medicine are developed systematically as professional statements concerning the diagnosis, treatment, and aftercare for specific types of diseases. The Institute of Medicine in Washington, DC, defines clinical guidelines as "systematically developed statements to assist practitioner and patient decisions about appropriate health care for specific clinical circumstances" 
(155). The recommendations contained in guidelines are based on and summarize the research literature and established clinical practice.

The use of clinical guidelines has become widespread, and this development is supported by professional communities, health authorities, and patients' organizations in many countries. The aim of such guidelines is to assist clinicians in following evidence-based practice in the diagnosis and treatment of their patients (156). However, guidelines are not commands or orders, and personal treatment decision making in consultation with the patient should not be discarded in favor of evidence-based treatment alternatives (157). Deviations from guideline recommendations require detailed documentation of the reasons in the patient's medical record. For most tumor groups, there are international (EAU) guidelines (31), American Urological Association (AUA) Prostate Cancer Guidelines (158), NCCN Clinical Practice Guidelines in Oncology (51), national guidelines (Handlingsprogrammet for prostatakreft (46), Nationälla riktlinjer för prostatacancersjukvård 07 (159)), and, frequently, local guidelines at major hospitals, such as NRH (DNR retningslinjer for prostata kreft 2005).

To ensure that guidelines remain useful to clinicians, continuous updating with incorporation of new data and new insights is essential. This is a challenge for the authors of guidelines, especially national and local hospital guidelines, because they have to be updated continuously according to new research findings and developments in clinical practice. According to Shekelle et al. (160), as a general rule, guidelines should be reassessed for validity every 3 years. The EAU Prostate Cancer Guidelines were first published in 2001, and partial updates were published in 2003, 2005, 2007, 2009 (full revision), 2010, 2011, and 2012. There have been significant changes since 2001; for example, in the 2012 edition, the number of pages increased to 164, from 62 in 2001. Comparison between the AUA PCa guidelines and the latest update of the 2012 EAU PCa guidelines shows minor differences in their recommendations.

Table 1.4. Major changes in the 2012 EAU PCa guidelines compared with the 2003 edition

\begin{tabular}{|l|}
\hline A chapter about methodology \\
\hline A chapter on risk factors \\
\hline A chapter about screening and early detection \\
\hline More details about diagnoses \\
\hline TNM classification from 2009 (minor difference) \\
\hline $\begin{array}{l}\text { Additional information on watchful waiting, active surveillance, radical prostatectomy, } \\
\text { radiotherapy, and palliative treatment }\end{array}$ \\
\hline
\end{tabular}

The guideline concept has been criticized, and some clinicians oppose the application of guidelines in their practice (161). Guideline authors are aware of the risk of bias in the 
recommendations when the highest levels of evidence are lacking. Grol et al. (162) showed that many guidelines have been based more on experts' opinions than on high-level evidence. Accordingly, there is a risk that recommendations reflect the view of opinion leaders, the culture at leading treatment centers, or the personal interests of the guideline developers rather than evidence-based findings.

The recommendation designation in guidelines indicates the strength of a recommendation. This requires that guideline authors make judgments about the relative strengths and weaknesses of study data, make value judgments about the relative importance of the risks and benefits identified according to the evidence, and synthesize conflicting findings from multiple studies.

Many guidelines, including the EAU and the Norwegian guidelines produced by government health authorities, use the Appraisal of Guidelines for Research and Evaluation (AGREE) (163) instrument to provide a framework for assessing the quality of clinical practice guidelines. The AGREE instrument comprises 23 key items organized in six domains (Table 1.5). Each domain is intended to capture a separate dimension of guideline quality.

\section{Table 1.5. Structure and content of the AGREE instrument}

\begin{tabular}{|c|c|}
\hline Scope and purpose & $\begin{array}{l}\text { Is concerned with the overall aim of the guideline, the specific clinical } \\
\text { questions, and the target patient population (items } 1-3 \text { ) }\end{array}$ \\
\hline Stakeholder involvement & $\begin{array}{l}\text { Focuses on the extent to which the guideline represents the views of its } \\
\text { intended users (items } 4-7 \text { ) }\end{array}$ \\
\hline Rigor of development & $\begin{array}{l}\text { Relates to the process used to gather and synthesize the evidence, and } \\
\text { the methods used to formulate and update the recommendations (items } \\
8-14 \text { ) }\end{array}$ \\
\hline Clarity and presentation & Deals with the language and format of the guideline (items 15-18) \\
\hline Applicability & $\begin{array}{l}\text { Pertains to the likely organizational, behavioral, and cost implications } \\
\text { of applying the guideline (items 19-21) }\end{array}$ \\
\hline Editorial independence & $\begin{array}{l}\text { Is concerned with the independence of the recommendations and } \\
\text { acknowledgment of possible conflict of interest from the guideline } \\
\text { development group (items 22-23) }\end{array}$ \\
\hline
\end{tabular}

The levels of evidence (Table 1.6) and grades of recommendation (Table 1.7) provided in most guidelines follow the listings because the aim of grading the recommendations is to provide transparency between the underlying evidence and the recommendation given. 
Table 1.6. Levels of evidence

\begin{tabular}{|l|l|}
\hline Level & Type of evidence \\
\hline $1 \mathrm{a}$ & Evidence obtained from meta-analysis of randomized trials \\
\hline $\mathrm{1b}$ & Evidence obtained from at least one randomized trial \\
\hline $2 \mathrm{a}$ & Evidence obtained from one well-designed controlled study without randomization \\
\hline $2 \mathrm{~b}$ & $\begin{array}{l}\text { Evidence obtained from at least one other type of well-designed quasi-experimental } \\
\text { study }\end{array}$ \\
\hline 3 & $\begin{array}{l}\text { Evidence obtained from well-designed nonexperimental studies, such as comparative } \\
\text { studies, correlation studies, and case reports }\end{array}$ \\
\hline 4 & $\begin{array}{l}\text { Evidence obtained from expert committee reports or opinions or clinical experience of } \\
\text { respected authorities }\end{array}$ \\
\hline
\end{tabular}

Modified from University of Oxford, Centre for Evidence-Based Medicine (CEBM) (164)

Table 1.7. Grades of recommendations

\begin{tabular}{|l|l|}
\hline Grade & Nature of recommendations \\
\hline A & Consistent level 1 studies \\
\hline B & Consistent level 2 or 3 studies or extrapolations from level 1 studies \\
\hline C & Level 4 studies or extrapolations from level 2 or 3 studies \\
\hline D & Level 5 evidence $o r$ troublingly inconsistent or inconclusive studies of any level \\
\hline
\end{tabular}

Modified from University of Oxford, Centre for Evidence-Based Medicine (CEBM) (164)

Translating scientific evidence into daily practice is a complex undertaking. Clinical guidelines can improve health-care delivery, but there are a number of challenges in guideline adoption and implementation. Factors influencing the effective implementation of guidelines remain poorly understood. Identifying and understanding the barriers and facilitators are important to the development of effective implementation strategies. There is a growing literature that explores the barriers to the implementation of clinical guidelines in health care and identifies effective strategies for translating research into practice $(165 ; 166)$. Results of studies in the United States and the Netherlands $(167 ; 168)$ suggest that about $30-40 \%$ of patients do not receive care according to current scientific evidence, and about $20-25 \%$ of the care provided is not needed or is potentially harmful.

\subsection{Summary}

With the exception of basal cell carcinoma, $\mathrm{PCa}$ is the most common cancer among men in the developed world. Although the prognosis for $\mathrm{PCa}$ is generally favorable, mortality is high and is second only to lung cancer in Scandinavian men. The treatment benefit of radical therapy in localized $\mathrm{PCa}$ is the subject of debate and, until recently, was not documented by randomized trials. For patients 
with very low-risk PCa, AS instead of immediate therapy seems to be a preferable treatment strategy. Several active treatment options are available, however, including different forms of surgery and RAD supplemented by hormone therapy for some patients (169). The increasing complexity of treatment options has led to an urgent need for generally accepted clinical guidelines. The EAU PCa guidelines were first published in 2001, with partial updates in 2003. Given this background, studies examining adherence to guidelines are important in assessing the quality of care, especially for cancer centers offering patients several treatment modalities.

Local therapy for PCa harbors a risk of causing permanent AEs, which may affect the patient's QoL. Therefore, in the late 1990s, several PCa-specific questionnaires were developed and tested psychometrically for the prospective measurement of AEs related to therapy. For PCa, the typical AEs examined affect urinary, bowel, and sexual function, and the bother related to these functions. New statistical tools were introduced. One was to analyze the data on AEs reported after therapy and to identify the proportions of patients regaining a certain percentage of their baseline function score at later time points (PBS). A second method, the GEE, was developed to analyze the associations between treatment related AEs and final outcomes after adjusting for baseline scores and covariates.

Given this background, it is important to study further the impact of the psychosocial effects of treatment on urinary, bowel, and sexual function, and bother, and to study further the different statistical methods that can be used to help patients select the treatment modalities in the context of AEs. 


\section{THIS THESIS}

\subsection{Background}

During the decade preceding 2004, curative treatment for localized or locally advanced PCa at NRH comprised either (1) ORRP or (2) conformal EBRT at a target dose of 70-74 Gy. As devised by the D'Amico risk group, RAD was combined with neoadjuvant ADT for 1-3 years' duration. In 2004, two new treatment modalities were introduced in Norway at NRH: (1) RALP and (2) HDR-BT.

The availability of several curative therapeutic options and the increase in the number of patients triggered a need for treatment guidelines for nonmetastatic PCa at NRH beyond those published by the EAU in 2003 (170). Close monitoring of AEs was warranted. In 2004, the UCLAPCI questionnaire became available for systematic recording of AEs after PCa treatment. At the initiative of NRH physicians and with the permission of Litwin, the UCLA-PCI was translated into Norwegian following the published recommendations of Acquadro et al. (142). At the same time, previous studies indicated the significance of psychological factors in patients' perception of AEs (171).

Against this background, a prospective study that collected relevant data using multiple questionnaires was initiated for patients referred to NRH for curatively intended treatment of PCa. During the 2004-2007 period, NRH was the referral hospital for the Southern Norway Health Region, which covers a population of about 1.6 million people. The study included:

a. baseline tumor characteristics and demographics

b. UCLA-PCI measurements

c. other self-reported instruments:

i. SF-12

ii. Hospital Anxiety and Depression Scale (HADS)

iii. Fatigue Questionnaire (FQ)

iv. Short Version of the Eysenck Personality Questionnaire (EPQ-18)

d. follow-up.

The present thesis was based on this material and the project plan was decided in 2008 to focus on:

1) adherence to institutional treatment guidelines for localized and locally advanced $\mathrm{PCa}$

2) the development over time of AEs after curative treatment of PCa.

\subsection{Aims of the studies}

Paper I (172)

Clinicians' use of guidelines as illustrated by curative treatment of prostate cancer at a comprehensive cancer center 
- To examine and compare the use of different treatment modalities and adherence to the EAU PCa guidelines published in 2003 for PCa during period I (December 2004 through December 2005) and adherence to the in-house guidelines during period II (2006 through to July 2007).

- To explore reasons for deviations from the guidelines.

\section{Hypothesis:}

There is high adherence to both the EAU PCa guidelines and institutional guidelines even though enthusiasm for new technologies could lead to deviations from the guidelines.

Paper II (173)

Methods for prospective studies of adverse effects as applied to prostate cancer patients treated with surgery or radiotherapy without hormones

- To use two models to study the development pattern of AEs after RALP and RAD without ADT within 2 years after treatment: the proportions of patients regaining $90 \%$ of their baseline function score (PBS-90) and the GEE, representing a new type of multivariate analysis.

- In a prospective design, to examine the causes of sexual, bowel, and urinary dysfunction (typical dysfunctions) at 3, 6, 12, and 24 months after either RALP or RAD without ADT and to explore intergroup differences.

\section{Hypotheses:}

1) Both PBS-90 and GEE capture clinically relevant aspects of the development of AEs (dysfunctions; prediction of dysfunction at 24 months).

2) Different patterns of typical dysfunctions will emerge after RALP and RAD without ADT with clinically important intergroup differences.

Paper III (174)

\section{Bother problems in prostate cancer patients after curative treatment}

- To explore the posttreatment patterns of bother concerning typical dysfunctions ("typical bother") after RALP, RAD without ADT, and RAD with ADT.

- To investigate at what posttreatment times the different types of typical bother become stable and when significant associations with 24-month bother emerge.

- To examine the associations between psychosocial variables and typical bother at different times.

- To explore the relationships between typical bother and typical dysfunctions at various times.

\section{Hypotheses:}

1) Significantly different development patterns of typical bother will emerge from pretreatment until the 24-month follow-up after RALP, RAD without ADT, and RAD with ADT. 
2) At 6 months, the percentages of men with typical bother and the mean levels of bother are significantly associated with typical bother at 24 months.

3) Some psychosocial variables are significantly associated with mean typical bother scores at various times.

4) The correlations between typical dysfunction and corresponding typical bother are high at all time points examined.

\subsection{Methods}

\subsubsection{Patient recruitment}

From December 2004 to July 2007, patients undergoing curatively intended treatment for localized or locally advanced $\mathrm{PCa}$ at $\mathrm{NRH}$ were invited to take part in a prospective study of treatment-related AEs. The inclusion and exclusion criteria are given in Table 2.1.

Table 2.1. Inclusion and exclusion criteria for patients

\begin{tabular}{|l|l|}
\hline \multicolumn{1}{|c|}{ Inclusion criteria } & \multicolumn{1}{c|}{ Exclusion criteria } \\
$\begin{array}{l}\text { 1. Planned for curative treatment of } \\
\text { adenocarcinoma of the prostate }\end{array}$ & $\begin{array}{l}\text { 1. Other diseases that significantly affect } \\
\text { intestinal, bladder, or sexual function }\end{array}$ \\
$\begin{array}{l}\text { 2. Initial cancer diagnosis } \leq 24 \text { months before } \\
\text { treatment }\end{array}$ & $\begin{array}{l}\text { 2. Previous WW strategy } \\
\text { 3. Any salvage or adjuvant post-RALP treatment } \\
\text { for PCa during the time of the survey } \\
\text { 3. Age }<75 \text { years }\end{array}$ \\
4. No previous invasive cancer
\end{tabular}

During the inclusion period, 893 patients were treated for localized or locally advanced PCa at $\mathrm{NRH}$; of these, 34 were ineligible. Among the 859 eligible patients, 34 (4\%) declined to take part in the study, and 538 of the 825 (65\%) remaining patients participated. Most of the 287 eligible nonparticipating patients (35\%) did not receive an invitation to the study for administrative reasons, mainly because surgical patients arrived at the hospital in the morning of their day of surgery, leaving insufficient time to provide them with information about the study and to collect written informed consent (same-day surgery). 
Figure 2.1. Distribution of patients in the papers in this study

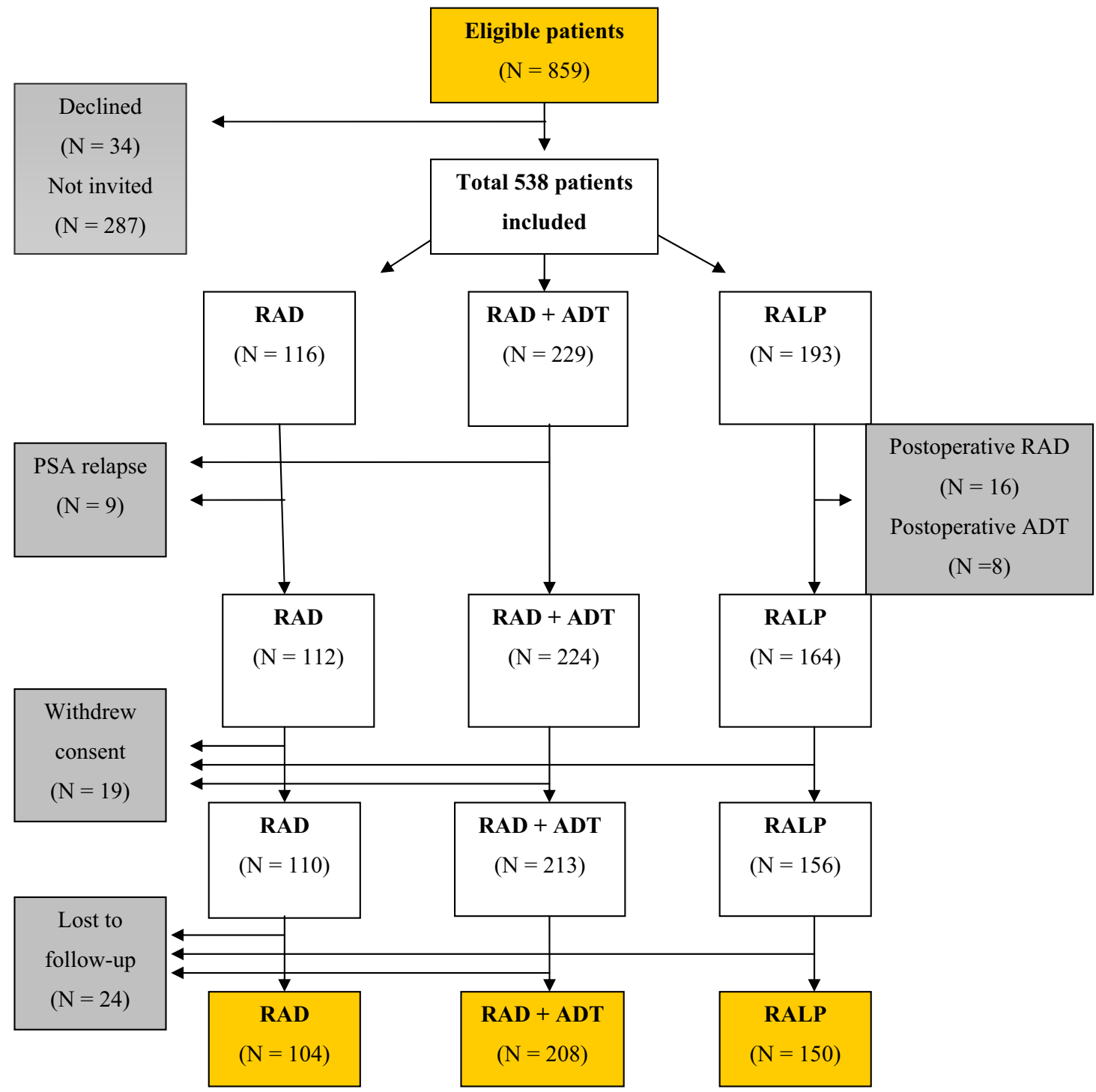

Paper I included all 859 eligible patients, paper II studied the patients treated with RAD without ADT and the RALP group (total $\mathrm{N}=254$ ), and paper III included the RAD + ADT group (total $\mathrm{N}=462$ ). In paper II, we reported on 539 recruited patients, versus 538 in paper III. This 
discrepancy was because, after being included in the study, one patient was found to have a previous diagnosis of malignant melanoma and therefore was excluded from the rest of the study.

\subsubsection{Treatment modalities}

The local treatment of recruited patients comprised either surgery or RAD.

All prostatectomies were RALP with or without lymphadenectomy. RALP was performed by a five-port transperitoneal approach using a three-arm da Vinci ${ }^{\circledR}$ system. According to the guidelines, during periods I and II, RALP was intended primarily for patients belonging to the low and intermediate D'Amico risk groups. Nerve-sparing RALP was performed according to the two surgeons' judgment as to the feasibility in the individual patient.

RAD: Patients in the low-risk group were irradiated using a conformal four-field box technique (50 Gy to the seminal vesicles and 74 Gy to the prostate) without ADT. From the end of 2004, the nonsurgical treatment of patients belonging to the intermediate- and high-risk groups increasingly included a combination of conformal radiotherapy with HDR-BT as a boost (91). A small proportion of patients with $\mathrm{N}+$ disease (one or two lymph nodes) were treated with IMRT $(\mathrm{N}=23)$. Patients belonging to the intermediate- and high-risk groups receiving RAD were treated with ADT. Intermediate-risk patients received ADT for a total of 1 year, and high-risk patients were treated for 3 years until the end of 2007 and from then on were given 2 years of treatment. All groups received neoadjuvant ADT for 3-6 months.

Obturator lymphadenectomy was performed in patients with a PSA level $>10 \mu \mathrm{g} / \mathrm{L}, \mathrm{T}$ category $>\mathrm{T} 2 \mathrm{c}$, or Gleason score $>7$. An expert pathologist at NRH reassessed the pretreatment prostatic biopsies evaluated at local laboratories to check the Gleason categorizations.

\subsubsection{Periods and adherence to guidelines}

Period I: From the end of 2004 and throughout 2005, a slightly modified version of the 2003 EAU guidelines (170) was used at NRH (Table 2.2). The criterion of life expectancy $>10$ years left an opportunity for individual clinical interpretation; in general, NRH clinicians interpreted this criterion as an upper age limit of 70 years for surgical patients and 75 years for RAD patients based on the mean life expectancy of 78 years for Norwegian men (13).

Period II: In relation to this thesis, period II lasted from 2006 to July 2007. Institutional NRH guidelines were formally approved in October 2005, replacing the guidelines used in period I and recommending modified treatment strategies for patients with localized or locally advanced PCa. In a decision influenced by the publication of the SPCG-4 trial (175), the upper age limit for RALP was reduced to 65 years.

Throughout the study period, the hospital's urologists and oncologists met weekly to discuss and determine each patient's treatment based on information from the referral letter, supplementary 
examinations at the outpatient department, and current guidelines. In 2009 and 2010, the medical records of all patients treated during the two periods were reviewed to evaluate whether treatment was given according to the current guidelines, as follows.

Treatment according to guidelines (according group) referred to patients for whom guideline recommendations were followed without discussion between the medical specialists.

Treatment according to guidelines after discussion (discussion group) covered less obvious cases for which final treatment according to guidelines was decided after discussion between the medical specialists and the patient.

Treatment deviating from guidelines (deviance group) concerned patients who fulfilled the guideline criteria for either prostatectomy or RAD but who did not receive the recommended treatment. The surgical deviance group comprised patients who underwent prostatectomy, although the guidelines recommended RAD, whereas the RAD deviance group comprised patients who had RAD although the guidelines recommended surgery in such cases.

Table 2.2. Criteria of the 2003 EAU Guidelines and NRH Guidelines.

\begin{tabular}{|c|c|c|c|c|c|}
\hline \multicolumn{3}{|c|}{ EAU Guidelines, updated February 2003} & \multicolumn{3}{|c|}{ NRH Guidelines 2005} \\
\hline $\mathbf{R P}^{1}$ & RAD & Discussion & RALP & RAD & Discussion \\
\hline & & Patient's wishes & & & $\begin{array}{l}\text { Patient's } \\
\text { wishes }\end{array}$ \\
\hline $\begin{array}{l}\leq \mathrm{T} 2 \text { and } \\
\text { Gleason } \leq 7 \text { and } \\
\text { PSA }<10 \text { (low) } \\
\text { and life } \\
\text { expectancy }> \\
10 \text { years }\end{array}$ & $\begin{array}{l}\leq \mathrm{T} 3 \mathrm{~N} 0 \text { or } \\
\text { Gleason } 8-10 \\
\text { or PSA }>25 \\
\text { and life } \\
\text { expectancy > } \\
5-10 \text { years }\end{array}$ & $\begin{array}{l}\text { Small T3A and } \\
\text { Gleason 5-7 } \\
\text { and low PSA } \\
(10-25) \text { and life } \\
\text { expectancy }> \\
10 \text { years }\end{array}$ & $\begin{array}{l}\leq \mathrm{T} 2 \text { and } \\
\text { Gleason } \leq 7 \\
\text { and PSA }<10 \\
\text { and age } \leq 65 \\
\text { years PS } 0-1- \\
\text { (2) }\end{array}$ & $\begin{array}{l}\text { T3pN0 or } \mathrm{N}+ \\
\text { (IMRT) or } \\
\text { Gleason } 9 \text { or } \\
10 \text { or PSA }< \\
70 \text { or age } \leq 75 \\
\text { years, PS } 0-1- \\
2, \text { comorbidity } \\
\text { rendering } \\
\text { surgery } \\
\text { problematic }\end{array}$ & $\begin{array}{l}\text { Small T3A } \\
\text { and Gleason } 6, \\
\text { PSA }<10 \text { or } \leq \\
\text { T2 or Gleason } \\
=8 \text { or PSA } \\
10-30 \text { or age } \leq \\
65 \text { years }\end{array}$ \\
\hline
\end{tabular}

${ }^{1} \mathrm{RP}$ was performed as open RP until December 2004, thereafter as RALP.

\subsubsection{Collection of clinical data}

Pretreatment variables (TNM categories [2002], Gleason scores for the prostate biopsies, pretreatment PSA levels) were collected from the patients' medical records at NRH. All patients were allocated to a pretreatment risk group according to the method of D'Amico et al. (49). 


\subsubsection{Self-report instruments}

\section{UCLA-PCI}

The UCLA-PCI assesses both generic QoL using the SF-12 questionnaire and treatment-related AEs of patients treated for PCa (146). AEs are conceptualized according to both function and bother (section 1.9.1). The UCLA-PCI comprises six dimensions, which are quantified using Likert scales: urinary function (five items), bowel function (four items), and sexual function (eight items). Urinary, bowel, and sexual bothers (typical bothers) are covered by one item each. As mentioned previously in section 2.1, Professor Mark Litwin, MD, who developed the UCLA-PCI, granted us permission to create a Norwegian translation according to common procedures for translation and back-translation with correction of items.

The dimensional scores of the UCLA-PCI were then transformed into scales ranging from 0 to 100. Higher scores reflect better function and less bother. Previous studies have shown that the internal consistency is good, with Cronbach's alpha coefficients $>0.70$ (146).

\section{Short Form-12 (SF-12)}

The SF-12 is a shortened version of the SF-36 (176) and exhibits the same good psychometric characteristics (177). The SF-12 covers two aspects of generic QoL, expressed as the physical composite summary (PCS) and mental composite summary (MCS) scores. The original ratings were T-transformed so that the mean PCS and MCS scores in the general Norwegian male population were set at 50 points, and one standard deviation was set at 10 points $(178 ; 179)$.The SF-12 ratings were used in paper III.

\section{$H A D S$}

The HADS was developed to measure symptoms of anxiety and depression in patients with somatic diseases (180). The HADS comprises subscales for anxiety and depression, each with seven items, that record the anxiety and depression experienced in the past week. The item scores range from 0 (not present) to 3 (highly present). The subscale scores thus range from 0 (low) to 21 (high). Caseness of depression and anxiety is defined as a score of $\geq 8$ on each scale. This cutoff point provides the best balance between sensitivity and specificity in many studies. There is an extensive international literature showing good psychometric properties of the HADS, and the psychometric properties of the Norwegian version of the HADS were shown to be excellent in the Nord-Trøndelag Health Study (181). The HADS is also documented to work well for cancer patients (182). At baseline, Cronbach's alpha was 0.71 for HADS depression and 0.72 for HADS anxiety. The HADS was used in paper III. 
The FQ was developed and validated by Chalder and colleagues in 1993 (183). The FQ comprises 11 items to measure the level of fatigue experienced by the patient in the past month. The FQ contains mental (four items) and physical (seven items) aspects of fatigue, and the ratings are from 0 to 3 , with higher scores indicating more fatigue. The mental and physical fatigue sum scores range from 0 to 12 and from 0 to 21 , respectively. The total fatigue score is the sum of all 11 items, and the range is $0-33$. Caseness of CF is defined as the sum of dichotomized scores $(0-1=0,2-3=1)$ of $\geq 4$ and duration of 6 months or more (184). The psychometric properties of the Norwegian FQ translation are considered to be good (121). The FQ was used in paper III; in that sample the Cronbach's alpha was 0.84 for total fatigue.

\section{$E P Q-18$}

The EPQ comprises three basic personality traits; however, we only assessed neuroticism because it is associated with many types of somatic and mental morbidity (185). The answer "yes" was scored as 1 and "no" as 0 , giving a neuroticism score range of 0 to 6 (186), which is interpreted as being very nervous (high score) to feeling very safe (low score) (187). At baseline, Cronbach's alpha 0.64 was for neuroticism. Neuroticism was included in paper III.

\subsubsection{Statistical considerations}

\section{All papers}

Continuous variables were analyzed with $t$ tests, and categorical variables with Pearson's chi-square test. Nonparametric tests were used in cases of skewed distributions. All analyses were performed on SPSS, version 15, or PASW for PC, versions 17 and 18.

\section{Paper I}

Continuous variables are described as median and range, and categorical variables as proportions. The level of significances was set at $\mathrm{p}<0.05$ and all tests were two sided.

\section{Paper II}

Descriptive statistics included the mean and standard deviation (SD) for continuous variables. The level of significance was set to $\mathrm{p} \leq 0.01$ because of multiple comparisons, and all tests were two sided. At each time point, the mean functional scores of the two therapeutic groups were compared using linear regression analyses adjusted for confounders (D'Amico risk group, age, and education).

Within each of the two therapeutic groups, factors associated with typical dysfunctions were analyzed using the GEE technique and the PBS statistics. In the GEE method, associations between independent variables (treatment modality, age, level of education, D'Amico risk group, and function 
scores at various times) were analyzed with the function at 24 months as the dependent outcome. The strengths of the associations are expressed as beta coefficients with $95 \%$ confidence intervals. Wald statistics were included to show if the predictors made a significant contribution to the prediction of outcome if the value was different from zero.

In the PBS-90, as used by Malcolm et al. (152), we calculated the proportion of patients who reached $90 \%$ of their pretreatment function scores at the different posttreatment times and evaluated when this proportion did not differ from the situation at 24 months. The PBS-90 percentages were dichotomized according to whether the patients did or did not achieve $90 \%$ of the baseline or better function. Patients with a pretreatment function score $<30$ were excluded from the analyses because they could have a high PBS-90 with a low absolute score. No patients were excluded because of low urinary function (score $<30$ ), one was excluded because of low bowel function, and $40(16 \%)$ were excluded because of low sexual function. As described by Malcolm et al. (152), the changes in PBS90 with time were examined using chi-square tests or Fisher's exact tests if there were $<25$ patients in one of the groups. We used Kaplan-Meier curves to analyze the proportions of patients whose function scores returned to PBS-90.

\section{Paper III}

Descriptive statistics in paper III include the mean and SD for continuous variables and proportions for categorical variables. The GEE was used to identify factors associated with the bother level at 24 months. Independent variables were D'Amico risk group, age, and educational level at baseline, and anxiety, depression, neuroticism, total fatigue, and PCS-12 and MCS-12 at each time. The strength of the associations is expressed as beta coefficients with $95 \%$ confidence intervals. As in paper II, Wald statistics were used. We used repeated measurement (ANOVA) to analyze the change in the bother score with time within each of the three treatment groups because there were no missing values. At each follow-up time, typical bother was reported as both continuous and categorical variables. In contrast to the interpretation of means, which were used in similar research papers, categorical findings are easy to explain to individual patients.

Similarly to paper II, in paper III, we calculated the percentages of patients who had returned to their baseline bother score (PBS-100) at each time point. Because of the scoring steps of the single bother items, we chose "return to $100 \%$ of the baseline score" as the outcome. For the same reason, and in contrast to the procedure followed by Malcolm et al. (152) and by us in paper II, we did not exclude any patients. Bother stability was defined as the time when the percentages of patients who had recovered to $100 \%$ of the baseline bother score did not differ significantly from those at 24 months. 
To analyze the relationship between bother and function, we used Spearman's correlation coefficients with the following classification: low $< \pm 0.3$, medium \pm 0.31 to \pm 0.49 , and large $\geq \pm 0.50$ (188).

The crude and adjusted associations between treatment modalities as independent variables and bother dichotomized as present or absent (reference) at all time points were analyzed using univariate and multivariate logistic regression analyses. We adjusted for D'Amico risk groups (49), age, and educational level at baseline; and anxiety, depression, neuroticism, total fatigue, PCS-12, and MCS-12 at every time point. The strength of each association is expressed as an odds ratio (OR) and $95 \%$ confidence interval.

The level of significance was set to $p<0.01$ because of the inclusion of multiple comparisons, and all tests were two sided. We also report some interesting results that show only a trend toward significance $(\mathrm{p}=0.01)$.

\section{ETHICAL CONSIDERATIONS}

All participants provided written informed consent to participate, including permission for the retrieval of relevant data from their medical records. The study was approved by the Regional Committee for Medical Research Ethics of Southern Norway and by the Norwegian Data Inspectorate.

\section{RESULTS}

\subsection{Paper I}

A total of 859 patients were included in this study: 315 (37\%) patients during period I (end of 2004 and throughout 2005) and 544 (63\%) during period II (2006 to mid-2007). Most PCa patients ( $=$ $713,83 \%$ ) were treated according to current EAU and in-house guidelines; 569 patients (66\%), 144 patients (17\%), and 146 patients (17\%) were allocated to the according, discussion, and deviance groups, respectively.

Of the 146 patients in the deviance group, 119 men (82\%) had surgery (RALP), and the other 27 patients received RAD instead of RALP. The distributions in the deviance group were $12 \%(\mathrm{~N}=$ 37 ) in period I (end of 2004 to 2005$)$ and $20 \%(\mathrm{~N}=109)$ in period II (2006 to mid-2007). The size of the surgical group increased by more than a factor of two, from $\mathrm{N}=111$ in period $\mathrm{I}$ to $\mathrm{N}=250$ in period II. By contrast, the number of irradiated patients decreased from $10 \%$ to $2 \%$ from period I to period II in the deviance group. The reasons for the deviation in period II were age $>65$ years $(\mathrm{N}=70)$ and surgery in patients with $\mathrm{T} 3$ tumors $(\mathrm{N}=10)$, Gleason score $>8(\mathrm{~N}=13)$, and combinations $(\mathrm{N}=$ 26). According to the medical records, 87 men $(73 \%)$ in the surgical deviance group chose their treatment based on information received from the referring physician and/or the urologists at NRH. 
Deviance from guidelines in the RAD group $(\mathrm{N}=27)$ occurred because of the patients' expectations about preserving sexuality and/or fertility. Comorbidity was the reason for RAD in five of the patients.

\subsection{Paper II}

A total of 254 PCa patients participated in this study; 150 patients were treated with RALP and 104 patients with RAD without ADT.

Within 6 months after treatment with RALP or RAD without ADT, the percentage of men who recovered to $90 \%$ of their baseline urinary and sexual functions stabilized. The percentage of patients who had recovered at this time did not differ from that observed at 24 months. The similar percentages of men who recovered bowel function had stabilized at 3 months for both treatment modalities. The GEE showed that the scores for urinary, sexual, and bowel functions at 6 and 12 months were associated significantly with the function scores at 24 months. Age at baseline was predictive for sexual and bowel dysfunction at the 24-month follow-up.

These results show that the GEE is an acceptable method for predicting dysfunction at 24 months and that the PBS-90 informs the patient of the time at which his dysfunctions will become stable. Therefore, both the PBS-90 and GEE have merits and supplement each other in the context of outcome assessment.

RALP patients experienced a significant reduction in sexual function 24 months after treatment. At all posttreatment times, the mean sexual function scores were significantly lower in patients treated with RALP than in those treated with RAD without ADT. RALP patients also showed a reduction in urinary function, whereas only slight impairment of urinary function was reported by patients treated with RAD without ADT. For bowel function, the reduction was limited to the RAD without ADT group; significantly better bowel function was reported at all times after RALP compared with after treatment with RAD without ADT.

\subsection{Paper III}

Each of the three primary therapies for PCa — RALP, RAD, and RAD with ADT—produced characteristic patterns of changes in urinary, sexual, and bowel bother during the first 2 years after treatment. Sexual (70\%) and urinary bother (40\%) were the most frequent concerns in RALP patients, whereas bowel bother (41\%) was most common among irradiated patients. 
Figure 4.1. Mean scores of bother at various times and findings of repeated-measures ANOVA at baseline and after 3, 6, 12, and 24 months of follow-up in patients treated with RALP, RAD, and RAD with ADT (identical to Figure 2 in paper II)

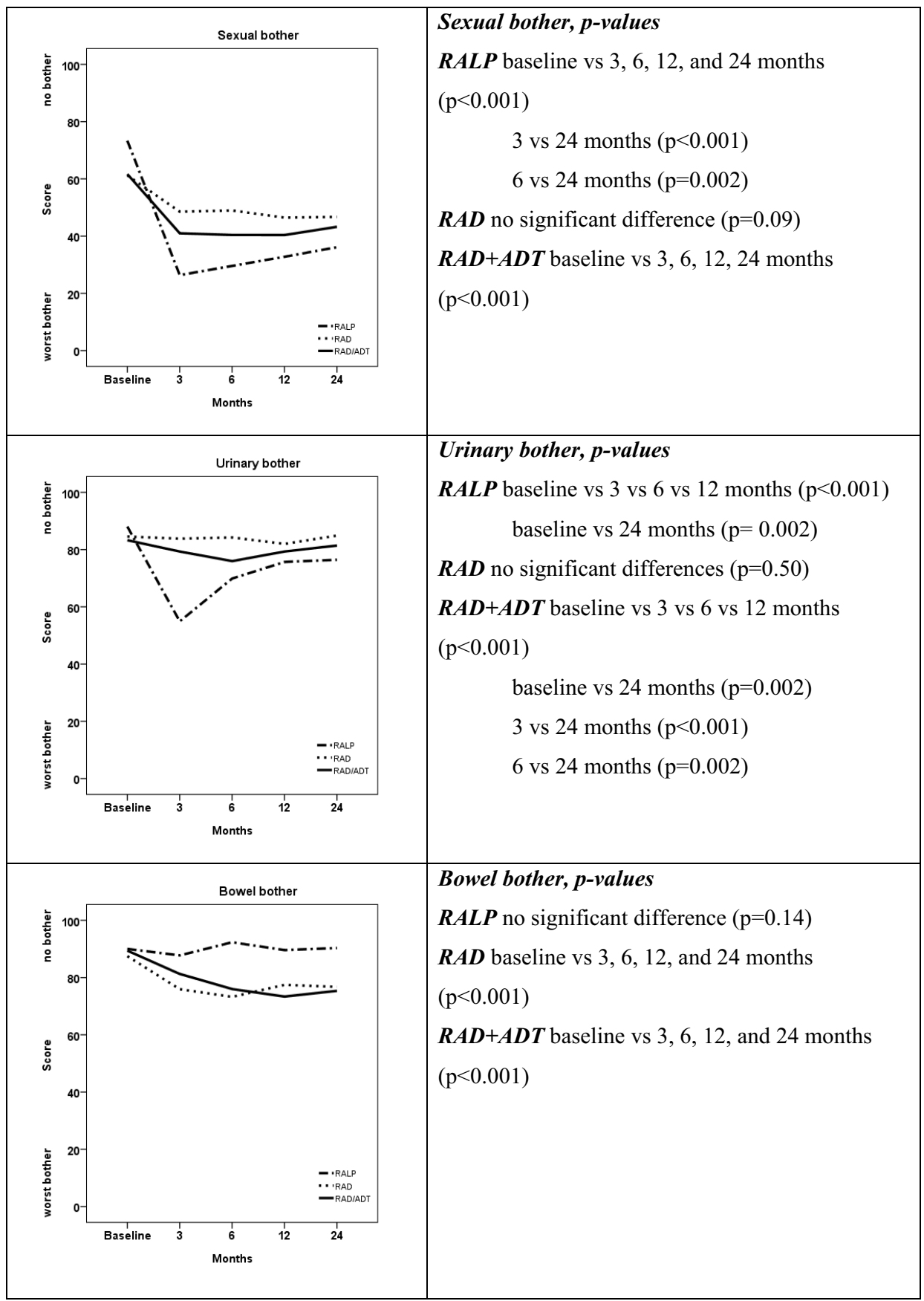


The PBS-100 showed that by 3 months for some bother variables and within 6 months after treatment for all variables, the percentages of men with all typical bother variables had stabilized and did not differ significantly from the baseline levels at 24 months (Figure 4.1).

The GEE showed that the demographic and psychosocial variables at baseline, except for high neuroticism, had hardly any influence on any of the three bother domains. There was a trend toward significance $(\mathrm{p}=0.01)$ for urinary bother at 24 months. Sexual bother at 24 months was significantly positively associated with sexual bother at $3(p=0.001), 6(p<0.001)$, and 12 months $(p<0.001)$. Higher urinary bother at $6(\mathrm{p}=<0.001)$ and 12 months $(\mathrm{p}=0.002)$ was significantly associated with higher urinary bother at 24 months. Bowel bother at 12 months $(\mathrm{p}=0.006)$ was significantly associated with bowel bother at 24 months, whereas bother at 6 months showed a trend toward significance $(p=0.01)$.

The risks of sexual and urinary bother were significantly lower in irradiated patients than in those treated with RALP. The risk of bowel bother increased in the irradiated patients, although it reached significance only for the RAD group at 6 and 12 months ( $\mathrm{p}=0.002$ and $\mathrm{p}=0.006$, respectively). Multivariate analyses showed that high neuroticism at baseline was significantly associated with high sexual bother at 3 months (OR 1.26, $\mathrm{p}=0.007)$ and with high urinary bother at 24 months (OR 1.40, $\mathrm{p}=0.007$ ). At baseline, reduced physical QoL (PCS-12) was significantly associated with sexual bother at baseline (OR 0.95, $\mathrm{p}=0.003$ ). Reduced physical QoL at 3 months was associated with bowel bother at the same time point (OR 0.88, $\mathrm{p}<0.001)$, and reduced physical QoL at 24 months was associated with urinary bother at the same time point (OR $0.85, \mathrm{p}<0.001)$.

Our findings show a strong relationship between function and bother scores for the urinary and bowel domains (Spearman correlation coefficient $\geq \pm 0.50$ ) and contrast with the findings related to sexuality.

\section{DISCUSSION}

\subsection{Methodological considerations}

\subsubsection{Cross-sectional and longitudinal studies}

To satisfy the objectives of paper I within each of the two periods of the cross-sectional study, we aimed to assess adherence to institutional treatment guidelines for curatively intended treatment of $\mathrm{PCa}$ in 859 patients. By comparing the results from the two periods, we were able to assess eventual time-dependent changes, thus adding a "longitudinal" aspect to our results. Information collected at one time point gives only a "snapshot" of the situation. Cross-sectional studies are suitable for assessing prevalence rates and detecting associations between variables (189). A cross-sectional study design does not provide information about causality, but the results of cross-sectional studies are suitable as a basis for administrative or political initiatives and decisions, and for making hypotheses about causality to be tested in studies with a more rigorous design. 
In papers II and III, we assessed AEs after different treatments for localized and locally advanced $\mathrm{PCa}$ at different times up to 2 years and compared these with the pretreatment status. These are prospective longitudinal studies because the information was obtained from the same individuals at more than one time point (189). Because a specific exposure occurs before the development of a disease or AEs, longitudinal studies may help elucidate the associations between exposure and a health outcome, and may help identify the predictors of AEs after treatment (190).

\subsubsection{Bias}

Bias can be defined as systematic error arising from the design or conduct of a study. This systematic error results from flaws in either the selection of study participants or the procedures for gathering relevant information about exposure and/or disease. The observed study results tend to differ from the true results in the reference population; this tendency toward erroneous results is called bias. A systematic error (bias) should be distinguished from a sampling error because of random variability, which results from the use of a study sample to estimate the study parameters in a reference population. The sample estimates may differ substantially from the true parameters because of random error, especially if the number of individuals included is small.

\subsubsection{Selection bias}

A selection bias is operating if the selected patients and controls differ systematically from their respective populations. This thesis included only patients treated at NRH, and we cannot exclude the possibility that these patients differ from patients treated curatively at other Norwegian hospitals, for example because of sociodemographic variables such as a higher level of education. In papers II and III, a relatively large percentage of eligible patients were not invited to participate. The main reason was lack of time for surgical patients who arrived at NRH in the morning of their day of operation (same-day surgery). To determine whether there was a selection bias for the recruited patients, we performed attrition analyses for papers II and III. The Gleason score, T category, and PSA level at baseline did not differ significantly between participants and nonparticipants. The same analysis was performed on those who withdrew or who delivered incomplete data, and we found no significant differences between participants and nonparticipants for the above-mentioned variables. However, we cannot rule out the possibility that those who withdrew from the study or were lost to follow-up had more dysfunction, were more bothered, or suffered more from psychosocial problems after treatment than the participating patients. Thus, we cannot exclude the possibility that nonparticipants and participants differed systematically on the outcome measures.

\subsubsection{Confounding factors}

Confounding factors are variables in statistical models that correlate (positively or negatively) with both the dependent variable and the independent variable. In papers II and III, an important aspect of 
the statistical analyses is that we adjusted for possible known confounders. In paper II, RALP and RAD without ADT were compared. Because of the guidelines, there were some differences in pretreatment tumor characteristics between the two treatment groups; that is, RALP patients were significantly younger, were more frequently employed, and were better educated compared with RAD patients. RALP patients also had lower D'Amico risk group scores than RAD patients.

Confounding factors such as the levels of specific variables at baseline at other times in the study are adjusted for in GEE analysis. Nevertheless, there are some limitations to this strategy. The GEE statistical tool includes concurrent adjustment for other associated and possible confounding variables and therefore the association between the independent variables of interest and the outcome is analyzed with a minimum of error from the confounding factors. As a rule, there should be at least 10-15 events for each covariate included in a regression model. Avoidance of a type II statistical error (not detecting existing differences) thus required a sufficient number of patients, which was the case in paper II and paper III (RAD, $\mathrm{N}=104$; RALP, $\mathrm{N}=150$ ).

In papers II and III, the GEE method adjusted for confounders assessed before treatment and during the follow-up. In paper III, analysis of the 24-month outcomes identified D'Amico risk group, age, educational level, anxiety, depression, neuroticism, total fatigue, PCS-12, and MCS-12 as potential confounders. In all three papers, the baseline tumor characteristics and sociodemographic and psychosocial factors differed between the three treatment groups. We used multivariate analyses to adjust for sexual, urinary, and bowel bother at baseline and at later times, and to eliminate the effects of confounding factors. However, not all potential confounders, such as civil status and somatic comorbidity, were included in the model in paper III.

\subsubsection{Information bias}

Information bias has two meanings. First, it can refer to the presence of incorrect information regarding the status of the sampled individuals versus the status of the controls. We do not consider this type of bias to be relevant to this thesis. Second, information bias may refer to systematic deviations of key information or responses to the questionnaires completed by the participants. To minimize the risk of information bias related to cancer-related variables, the medical records were examined several times. However, we cannot rule out the possibility that patients entered the "socially" correct answers rather than more personally correct answers for some questions, particularly those relating to sexual function and bother. During the work on this thesis, it became evident that the registration of nerve-sparing procedures was not accurate. This is reflected in the two different ways that the nerve-sparing procedures were reported (paper II versus III), and is a source of information bias.

Interpretation bias is a type of information bias that is operating if patients or interviewers, deliberately or inadvertently, interpret questions or information systematically in a way not intended. 
For questionnaires, halo effects are well-known phenomena among responders, but we had no check for these through parallel interviews (191). However, our conclusion is that we do not consider interpretation bias to be a major operating factor in this thesis, especially because we used established and validated questionnaires to obtain valid and reliable information on the outcome measures.

\subsubsection{Recall bias}

Recall bias is operating if the patients, deliberately or inadvertently, systematically distort their responses regarding previous events because of memory problems or suppression. In the prospective studies, we asked mainly for current AEs and symptoms, and only a few retrospective demographic and clinical data were assessed. We have no reason to believe that these data were a source of recall bias.

\subsubsection{Internal and external validity}

Internal validity reflects whether the effects we found can be related to the causes that we consider, namely the use of guidelines (paper I) or the treatment modalities for PCa applied (paper II). For example, the relative absence of bowel bother after RALP or of urinary bother is expected, based on daily clinical experience, thus validating our patients' responses. We have no reason to believe that these results could have occurred because of other factors not examined.

External validity refers to the extent to which the study results can be generalized to the whole group of PCa patients receiving curatively intended treatment. To consider the internal validity, representativeness, possible bias, and confounding factors must be evaluated because they all may affect internal validity (190).

Papers II and III included patients who received RALP, RAD without ADT, or RAD with ADT. As noted above, many surgical patients were not invited to participate. We cannot exclude the possibility that the nonrecruited patients differed from those who participated. However, we performed an attrition analysis to compare the nonresponders and responders at baseline, and we found no significant differences in age, marital status, Gleason score, T category, PSA level, or D'Amico risk group. Therefore, we consider the internal validity of the results of the study of curatively treated PCa to be satisfactory.

Paper I showed that most treatments were performed according to local and EAU guidelines, and these treatments were considered the standard treatments for PCa in several European countries during the study's timeframe. The external validity of our results is supported by the consistency of our results with those of other study groups. Further confirmation requires replication of our study at similar university hospitals with similar available technologies.

When assessing external validity, the clinical $\mathrm{T}$ category must be considered a confounding factor. Intuitively, larger tumors would require more extensive treatment (more extended operations, 
larger target fields) and could therefore affect outcome (i.e., AEs from treatment). A higher percentage of patients with $\mathrm{T} 3$ tumors were operated on in our study compared with other recent publications $(137 ; 138)$. By contrast, a higher percentage of patients with advanced primary tumors (T3) were offered prostatectomy, as documented in other recent studies (192-194).

\subsection{Discussion of the main findings}

\subsubsection{Paper I}

Guidelines are developed to benefit patients by defining current standard management, but they may not function as intended if they are incorrect or are misinterpreted (195). Paper I addressed these concerns.

Of all PCa patients receiving curatively intended treatment at NRH during the study period, $17 \%$ were not treated according to current guidelines. This is slightly less than or equal to the values in the study by Grol et al. (196). These authors analyzed $>70$ evidence-based guidelines for family medicine in the Netherlands and found that recommendations were followed in $67 \%$ of the decisions, although there were large variations between physicians and between guidelines (196). In our study, the main reason for not being treated according to the guidelines was the age limit of 65 years for RALP, which was applied during the second data-collection period. This age limit contrasts with the 2003 EAU recommendations and raises the question of whether such a strict age limit should be stated in the guidelines. The results of the SPCG-4 trial were the basis for this age limitation in the NRH guidelines. In this trial, prostatectomy did not improve survival in patients aged $\geq 65$ years compared with controls (175). However, this was the result of a subgroup analysis. Although the experiences from the SPCG-4 should not be discarded, the trial's patients were not entirely comparable to today's patients with nonmetastatic PCa, because the PSA test and RALP were introduced after that trial was conducted. In addition, life expectancy is significantly higher today than it was 20-25 years ago, mainly because of reduced mortality from cardiovascular diseases. Retrospectively, it is evident that the 65-year age cutoff has never been applied strictly during the day-to-day decision-making process between urologists, oncologists, and patients at NRH.

After obtaining experience with the new robot platform, the surgeons felt confident to perform RALP in patients with T3 tumors. This explains why an increasing percentage of patients with T3 tumors were operated on and did not receive primary RAD, as recommended in the guidelines from period II. In agreement with this practice, a recent study suggested that patients with a high Gleason score of 8-10 may benefit from a prostatectomy, which can provide durable local control and favorable cancer-specific survival (197). We should not forget that most patients in this group selected surgery after consideration and discussion with their referring urologist or hospital urologist. However, 
the medical records do not reveal whether and to what degree the patient had the opportunity to discuss treatment alternatives with an oncologist.

In the SPCG-7 trial, in high-risk patients, RAD combined with hormones proved to be more beneficial up to age 75 years compared with hormones alone (55). Data for this age group and risk category are not available for surgically treated patients. For patients in the deviance group who chose RAD, the most frequent reason was to maintain sexual function. The differences between AEs after surgery and RAD shown in papers II and III support this consideration.

Our principal view is that institutional guidelines for a disease such as PCa with several treatment modalities available are important to ensure the quality of clinical care. Guideline-based medical practice must employ two strategies. First, deviance from guidelines should be documented in the patient's medical record. Second, regular monitoring of compliance with guidelines, updating of the scientific knowledge, and appropriate guideline revisions are needed. These two strategies will help avoid errors and ensure that the most recent knowledge is applied in the daily clinical management of patients.

In addition to providing support for patients and physicians, guidelines can be viewed as tools to help policy makers and health bureaucracies provide more consistent and cost-effective medical care. Important conclusions from our study are that guidelines should not be too strict and that they should allow individual well-reasoned deviations, provided such deviations are documented in the medical records. Finally, to justify any deviations from guidelines, clinicians should be aware of the level of evidence underlying the major recommendations in the guidelines.

Although the single-institution design of paper I might be viewed as a limitation, we believe that similar institutions experience similar guideline deviations and must also regularly and frequently analyze compliance with guidelines.

\subsubsection{Paper II}

The PBS-90 showed that, by 6 months after treatment, urinary function in patients treated with RALP and sexual function in patients treated with RAD without ADT had stabilized. For bowel function, 3 months elapsed before stabilization. GEE analyses showed that age at baseline was predictive for sexual dysfunction at the 24-month follow-up. At 6 and 12 months, urinary, bowel, and sexual function were significantly associated with their corresponding 24-month function. Patients treated with RALP had a significant and enduring reduction of sexual and urinary function 24 months after treatment compared with those treated with RAD without ADT. For bowel function, the reduction was smaller for both groups, and patients treated with RALP had significantly better bowel function at all time points.

These findings support previous studies showing that RALP and RAD without ADT produce different patterns of AEs $(113 ; 137 ; 138 ; 147 ; 152)$. Our findings are consistent with those of Pardo et al. 
(138), although they had a longer follow-up period (36 months) and studied open RP and as well as RALP. Pardo et al. found that RP regularly caused urinary incontinence and sexual dysfunction, whereas RAD and brachytherapy caused some sexual dysfunction. RAD also caused bowel AEs. We note that Pardo et al. (138) used the EPIC-50 questionnaire, which is a further development of the UCLA-PCI (see section 2.3.5). Our findings are also consistent with those of studies that included patients on hormonal treatment; for example, Litwin et al. (113) and Sanda et al. (137) found that urinary control and sexual function were better after RAD compared with RP and that RAD caused more bowel dysfunction.

We found significantly poorer posttreatment erectile function in our surgical patients compared with those of Pardo et al. (138), Malcolm et al. (152), Sanda et al. (137), and Litwin et al. (113). One possible explanation is that Litwin et al. (113), Sanda et al. (137), and Pardo et al. (138) studied only patients in clinical T1/T2 categories. In the sample of Malcolm et al. (152), more than $80 \%$ of the patients had cancer at less than the T2a stage. By contrast, our sample comprised RALP patients only, and a considerable proportion of the patients were at more advanced clinical $\mathrm{T}$ stages $(26 \%>$ T2b). To offer RALP to such high-risk patients reflects common clinical practice in many university hospitals (192-194), but increases the risk of postoperative erectile dysfunction because of the reduced opportunity for nerve-sparing surgery.

Sexual function was significantly better at baseline among RALP patients compared with irradiated patients, which was expected because the operated patients were significantly younger than the patients treated with RAD without ADT.

As noted in paper II, one limitation of our study is that the two treatment groups differed significantly at baseline (Table 1 in paper II). RALP patients were younger and there was a larger proportion of D'Amico low-risk patients in those treated with RALP than in those treated with RAD without ADT. Previous studies show that age and stage of PCa are important determinants of AEs (113). Despite this limitation, our results can help inform patients about the types of side effects to expect after various treatment modalities.

In paper II, we used both GEE and PBS-90 to examine the development of typical dysfunctions in PCa patients treated with either RALP or RAD without ADT. As mentioned earlier, one strength of the GEE method is the simultaneous inclusion of pre- and posttreatment variables in the same multivariate analysis. In contrast to GEE, PBS-90 is a univariate analysis that calculates the percentage of patients who return to $90 \%$ of baseline function. The results produced by PBS- 90 may be easier for patients to understand than those from GEE. To our knowledge, no previous studies have combined GEE and PBS-90 in the same prospective outcome study to maximize outcome prediction and to determine the time to stability of typical dysfunctions. No previous study has compared typical dysfunction after RALP or RAD without ADT. In the study by Pardo et al. (138), surgery was performed by radical retropubic prostatectomy. 
In many studies, posttreatment AEs are rated by physicians $(198 ; 199)$. Patients with PCa often report more frequent and more severe AEs than their physicians $(200 ; 201)$. These findings indicate the risk that physicians generally underestimate the burden of posttreatment AEs in their PCa patients. Therefore, as in our study, patient-reported observations are an important supplement to physicians' reports $(146 ; 202 ; 203)$.

When planning our study, the UCLA-PCI questionnaire was selected as a compromise between the interests of oncologists and urologists, for whom the strategy of self-reported AEs was a new methodology in 2004. A weakness of the UCLA-PCI questions is that irritative symptoms are poorly covered in contrast to the more recently developed EPIC-50 (149). These symptoms are relatively common after RAD treatment $(99 ; 137)$ and are important especially for the interpretation of AEs in RAD patients.

The strength of our study compared with previous studies $(113 ; 137 ; 152 ; 201)$ is the homogeneity of our treatment groups. Most other studies of typical dysfunctions are based on mixed samples that included patients treated both with and without neoadjuvant ADT and did not consider post-RP RAD. ADT may confound the effects of RP and RAD on typical dysfunctions, particularly sexual dysfunction (137). However, a considerable proportion of patients with PCa are treated with RP or EBRT without hormones. To our knowledge, the current study (paper II) and the study by Pardo et al. (138) are the only two studies of AEs in patients treated with RAD without ADT.

In our study, posttreatment dysfunction rather than oncological results represented the principal outcome, and we followed the patients for 24 months. The post-RP AEs occur shortly after the operation, with some recovery during the 24 months, whereas radiation may induce AEs that may develop or worsen during subsequent years. Therefore, a follow-up longer than 24 months would be of interest, especially if long-term AEs are influenced by the oncological outcome. However, according to the literature, function related to RAD shows only minor changes beyond 24 months after therapy $(138 ; 204)$.

The patients who participated in the surgery group were operated on by the two in-house surgeons with RALP competence. Nevertheless, the definition of nerve-sparing RP in paper II differed from that used in paper III. In the interval between the writing of these two papers and with the agreement of the operating surgeons, an independent evaluator reexamined the operation records concerning the performance of nerve-sparing procedures. Unexplainable discrepancies and inconsistencies were observed, and we can make no firm conclusions about the influence of the nervesparing procedure on sexual function in papers II and III. 


\subsubsection{Paper III}

In contrast to paper II, which used posttreatment dysfunction as the main outcome, paper III examined posttreatment bother. A third group of patients who had RAD combined with neoadjuvant ADT was added.

Sexual and urinary bother represented the most frequent concerns after RALP, whereas bowel bother was reported most often by patients treated with RAD with or without ADT. The GEE showed that the bother scores at 3 and 6 months were significantly associated with the bother scores at 24 months for all treatment groups. By 3 months for some bother variables and within 6 months after treatment for all variables, the percentages of men with all typical bother variables had stabilized and did not differ significantly from the baseline levels at 24 months. Function and bother for the urinary and bowel domains showed strong correlations, but not in the sexual domain. The associations between psychosocial factors and any typical bother were weak.

The finding that RALP patients had considerable sexual bother after treatment is consistent with findings from previous studies $(113 ; 152 ; 205)$. Our study showed slightly more typical bother than reported in previous studies $(113 ; 137)$. One possible explanation is that our sample included more patients with high clinical T categories. As noted in the 2012 EAU guidelines (31), it is important to inform patients in a high $\mathrm{T}$ category that they may experience several types of bother after surgery to avoid unrealistic expectations about posttreatment function.

As observed in other studies, we also found that the differences in mean levels of sexual bother between operated and irradiated patients declined over time (205-207). By contrast, the small differences in mean bowel bother scores were consistent over time. Bowel bother showed no significant improvement after 12 months for any of the RAD groups, a finding that is also consistent with that of previous studies $(117 ; 208)$. As discussed in paper III, the reduction in sexual bother over time for all three modalities may be explained at least partly by a response shift and may not reflect an improvement in function only. Sprangers and Schwartz argue that patients confronted with a lifethreatening malignancy adapt to this challenge by changing their internal standards and values (209). The reason the same response shift does not occur for bowel bother may be that the symptoms, such as rectal bleeding and rectal incontinence (117), are more insidious and more socially incapacitating. Another explanation may be that, although bowel dysfunction occurs frequently after RAD, it is of minor concern to most irradiated patients and does not elicit any response shift reaction. It would be difficult to prove statistically that there is any significant reduction of the limited degree of bowel bother observed.

Surprisingly, we found few significant associations between bother and psychosocial variables at baseline. Other authors (205;210-212) have reported such associations, although they also found them to be weak. The patient's personality traits (e.g., neuroticism) can influence the perception and reporting of posttreatment bother; this is discussed by Block et al. (210). 
As in a previous study by Litwin et al. (147), we observed strong correlations between urinary and bowel functions and bother within the individual patient. Unlike Litwin et al. (147), we did not find the same correlations between sexual bother and function. However, in a subsequent paper, Litwin et al. (206) stated that sexual function and sexual bother are "discrete psychometric constructs that are topically related but otherwise independent of each other". Our findings confirm this statement.

To our knowledge, few if any studies have identified the postoperative time when patients can expect stability in urinary, sexual, and bowel bother after curatively intended PCa treatment, and when "stable bother" can be predicted for the three treatment modalities. Unlike Malcolm et al. (152), in paper III we chose to calculate PBS-100 (instead of PBS-90) because the bother score of the UCLAPCI includes only five categories, which did not allow us to quantify recovery to $90 \%$ of the pretreatment bother score.

A limitations of paper III was that the UCLA-PCI questionnaire is not comprehensive enough regarding adverse hormonal effects, which can cause considerable symptoms (213). In retrospect, follow-up for 24 months after treatment can be criticized because some of the patients recruited early in the study, who received RAD with ADT for a total of 3 years, had just finished ADT treatment at their 24-month follow-up.

As with paper II, another limitation was the relatively large number of patients who were missed at inclusion. As mentioned in the general discussion and in the discussion of paper II, the daily routine at the hospital meant that it was difficult to approach all patients who were to undergo RALP. In retrospect, we might have circumvented this problem by mailing the information and the questionnaire to these same-day surgery patients. Such costly administrative experiences represent important learning for a later study. Our attrition analyses showed no significant differences in Gleason, T category, PSA level, and marital status between the included and omitted patients. However, we have no information about the psychosocial variables and comorbidities in the omitted patients, and we cannot ignore that this may reduce the external validity of our findings.

As mentioned in the discussion of paper II, information about the nerve-sparing procedure was not recorded accurately or consistently. To try to compensate for this, a more detailed definition of nerve sparing was used in paper III (73). Other studies have demonstrated an effect of nerve sparing on erectile function (137), and we cannot rule out the possibility that the nerve-sparing procedure affects sexual bother.

In retrospect, the use of medication should have been addressed more carefully in the questionnaires because some drugs influence sexual function. For example, beta-blockers can adversely affect sexual function (214). We should also have included questions about the use of medication for erectile dysfunction. 
The strengths of paper III are the prospective design, the relatively large number of patients included, and the analysis of the three treatment modalities offered concurrently to patients not undergoing adjuvant or salvage systemic or local therapy within 24 months. To our knowledge, only one previous study has compared bother after surgery with bother after RAD without ADT (138) and no other studies have compared all three treatment modalities, RALP, RAD with ADT, and RAD without ADT.

\section{CONCLUSIONS OF THE THESIS}

\section{Paper I}

- Overall adherence to the guidelines for curative treatment of PCa was high: $88 \%$ of the patients during period I were treated according to the 2003 EAU guidelines, and $80 \%$ in period II were treated according to NRH guidelines. Overly strict recommendations, such as age-based limits, are frequent reasons for nonadherence.

- Authors of guidelines should be careful not to impose overly strict limitations in the guidelines. Rather, guidelines should allow room for the preferences of individual patients and physicians based on well-established clinical experience. The reasons for deviations from accepted guidelines for individual patients should be documented in the patient's medical record. It is important that clinicians know the guidelines and the background for the guidelines (e.g., evidence grade A or D, etc.) because this is important information in the discussion with the patient. It should take more to deviate from a guideline based on level A evidence than on level D evidence.

- Adherence to guidelines should be monitored regularly. Because of the rapid development of new treatment techniques, guidelines should be revised regularly and frequently, and should include new evidence-based findings.

\section{Paper II}

- PBS-90 identifies the first postoperative time when, within a 24-month timeframe, the highest percentage of patients with almost complete recovery of pretreatment function has been reached. The GEE identifies the time at which the 24-month outcome can be predicted. Principally different patterns of AEs emerged after RALP and RAD without ADT. The principal dysfunctions were sexual and urinary functions for patients treated with RALP and bowel function for those treated with RAD.

- Six months after RP or RAD without ADT and within a 24-month observation period, the percentage of patients with $90 \%$ recovery of their baseline function had become stable. The levels of dysfunctions at that time are associated with those at 24 months. 
- The results of this prospective study should be considered during pretreatment counseling of patients with PCa who must choose their curative treatment by considering the risk of posttreatment AEs. The new knowledge about recovery and the ability to predict 24-month dysfunction could be incorporated into counseling and planning of posttreatment follow-up.

\section{Paper III}

- The standard curative treatment modalities for nonmetastatic PCa show distinct patterns for sexual, urinary, and bowel bother during the first 2 years after treatment. RALP patients reported mainly sexual and urinary bother whereas irradiated patients were bothered by bowel dysfunction.

- The PBS-100 results showed that the percentage of patients with posttreatment typical bother stabilized between 3 and 6 months after treatment. The GEE showed that bother at 6 months was significantly associated with bother at 24 months.

- Except for neuroticism, baseline psychosocial variables have little impact on urinary, bowel, and sexual bother.

- Bowel and urinary bother levels were strongly correlated with their corresponding functions, whereas the correlation between sexual bother and function was weak.

- The findings about the recovery of dysfunction-related bother and the discrepancy between sexual dysfunction and sexual bother are important issues to be communicated to the patients during preand posttreatment counseling.

\section{CLINICAL IMPACT AND FUTURE PROJECTS}

- In recent years, a number of national treatment guidelines have been designed in Norway for different tumor groups. However, adherence to these guidelines is rarely monitored. Based on our experience performing the research described in paper I, we recommend that adherence to guidelines should be monitored regularly and that guidelines should be updated regularly to include rapidly developing therapeutic improvements. Guidelines must allow room for individual decisions based on discussions between the patient and physician, and these decisions should be documented in the medical record.

- The projected 10-year relative survival rate for all stage of PCa in Norway is about 78\%, (5 year relative survival for localized PCa 97.3 \%) (1) meaning that most these patients must live with the AEs for many years. The findings about the prevalence of, recovery from, and prediction of AEs described in papers II and III provide important information for improving patient-physician communication before treatment and during follow-up. Hopefully, these results will help answer 
- As an increasing number of patients receive postoperative RAD or systemic ADT, the effects of multimodal treatment should be studied.

- Registration of self-reported AEs should be a part of the electronic medical record to allow for regular monitoring of treatment.

- This study highlights the importance of systematic data collection when new technologies are introduced into clinical practice, both to evaluate and to compare the benefits of a new technology in an unselected group of patients. 
(1) Cancer in Norway. Oslo: Cancer Registry of Norway; 2009.

(2) Kvale R, Auvinen A, Adami HO, Klint A, Hernes E, Moller B, et al. Interpreting trends in prostate cancer incidence and mortality in the five Nordic countries. J Natl Cancer Inst 2007 Dec 19;99(24):1881-7.

(3) Haas GP, Delongchamps N, Brawley OW, Wang CY, de la RG. The worldwide epidemiology of prostate cancer: perspectives from autopsy studies. Can J Urol 2008 Feb;15(1):3866-71.

(4) Hernes E, Johansson LA, Fossa SD, Pedersen AG, Glattre E. High prostate cancer mortality in Norway evaluated by automated classification of medical entities. Eur J Cancer Prev 2008 Aug;17(4):331-5.

(5) Sandblom G, Varenhorst E, Rosell J, Lofman O, Carlsson P. Randomised prostate cancer screening trial: 20 year follow-up. BMJ 2011;342:d1539.

(6) Schroder FH, Hugosson J, Roobol MJ, Tammela TL, Ciatto S, Nelen V, et al. Screening and prostate-cancer mortality in a randomized European study. N Engl J Med 2009 Mar 26;360(13):1320-8.

(7) Schroder FH, Hugosson J, Roobol MJ, Tammela TL, Ciatto S, Nelen V, et al. Prostate-cancer mortality at 11 years of follow-up. N Engl J Med 2012 Mar 15;366(11):981-90.

(8) Hugosson J, Carlsson S, Aus G, Bergdahl S, Khatami A, Lodding P, et al. Mortality results from the Goteborg randomised population-based prostate-cancer screening trial. Lancet Oncol 2010 Aug;11(8):725-32.

(9) Andriole GL, Crawford ED, Grubb RL, III, Buys SS, Chia D, Church TR, et al. Prostate cancer screening in the randomized Prostate, Lung, Colorectal, and Ovarian Cancer Screening Trial: mortality results after 13 years of follow-up. J Natl Cancer Inst 2012 Jan 18;104(2):12532.

(10) Collins MM, Barry MJ. Controversies in prostate cancer screening. Analogies to the early lung cancer screening debate. JAMA 1996 Dec 25;276(24):1976-9.

(11) Chou R, Dana T, Bougatsos C, Fu R, Blazina I, Gleitsmann K, et al. Report No.: 12-05161EF-1. 2011 Oct.

(12) Hernes E, Harvei S, Glattre E, Gjertsen F, Fossa SD. High prostate cancer mortality in Norway: influence of Cancer Registry information? APMIS 2005 Jul;113(7-8):542-9.

(13) Statistics Norway. www ssb no 2012

(14) Zaridze DG, Boyle P, Smans M. International trends in prostatic cancer. Int J Cancer 1984 Feb 15;33(2):223-30.

(15) Kolonel LN, Altshuler D, Henderson BE. The multiethnic cohort study: exploring genes, lifestyle and cancer risk. Nat Rev Cancer 2004 Jul;4(7):519-27. 
(16) Vykhovanets EV, Shukla S, MacLennan GT, Resnick MI, Carlsen H, Blomhoff R, et al. Molecular imaging of NF-kappaB in prostate tissue after systemic administration of IL-1 beta. Prostate 2008 Jan 1;68(1):34-41.

(17) Shankar E, Vykhovanets EV, Vykhovanets OV, MacLennan GT, Singh R, Bhaskaran N, et al. High-fat diet activates pro-inflammatory response in the prostate through association of Stat-3 and NF-kappaB. Prostate 2012 Feb;72(3):233-43.

(18) Carter BS, Beaty TH, Steinberg GD, Childs B, Walsh PC. Mendelian inheritance of familial prostate cancer. Proc Natl Acad Sci U S A 1992 Apr 15;89(8):3367-71.

(19) Bratt O. Hereditary prostate cancer: clinical aspects. J Urol 2002 Sep;168(3):906-13.

(20) Mitra AV, Bancroft EK, Barbachano Y, Page EC, Foster CS, Jameson C, et al. Targeted prostate cancer screening in men with mutations in BRCA1 and BRCA2 detects aggressive prostate cancer: preliminary analysis of the results of the IMPACT study. BJU Int 2011 Jan;107(1):28-39.

(21) TNM Classification of Malignant Tumours. 6th edn. Wiley-Liss:New York, 2002. 2002.

(22) Spigelman SS, McNeal JE, Freiha FS, Stamey TA. Rectal examination in volume determination of carcinoma of the prostate: clinical and anatomical correlations. J Urol 1986 Dec 1986;1228-30.

(23) Obek C, Louis P, Civantos F, Soloway MS. Comparison of digital rectal examination and biopsy results with the radical prostatectomy specimen. J Urol 1999 Feb;161(2):494-8.

(24) Smith JA, Jr., Scardino PT, Resnick MI, Hernandez AD, Rose SC, Egger MJ. Transrectal ultrasound versus digital rectal examination for the staging of carcinoma of the prostate: results of a prospective, multi-institutional trial. J Urol 1997 Mar;157(3):902-6.

(25) Liebross RH, Pollack A, Lankford SP, Zagars GK, von Eschenbach AC, Geara FB. Transrectal ultrasound for staging prostate carcinoma prior to radiation therapy: an evaluation based on disease outcome. Cancer 1999 Apr 1;85(7):1577-85.

(26) Masterson TA, Touijer K. The role of endorectal coil MRI in preoperative staging and decision-making for the treatment of clinically localized prostate cancer. MAGMA 2008 Nov;21(6):371-7.

(27) Schiavina R, Scattoni V, Castellucci P, Picchio M, Corti B, Briganti A, et al. 11C-choline positron emission tomography/computerized tomography for preoperative lymph-node staging in intermediate-risk and high-risk prostate cancer: comparison with clinical staging nomograms. Eur Urol 2008 Aug;54(2):392-401.

(28) Tumor-Node-Metastasis (TNM) classification of PCa 2002 (cancer principles and practice of oncology $7^{\text {th }}$ edition Vincent T. Devita 2005). 2005.

(29) Dickinson L, Ahmed HU, Allen C, Barentsz JO, Carey B, Futterer JJ, et al. Magnetic resonance imaging for the detection, localisation, and characterisation of prostate cancer: recommendations from a European consensus meeting. Eur Urol 2011 Apr;59(4):477-94.

(30) Mueller-Lisse UG, Scherr MK. Proton MR spectroscopy of the prostate. Eur J Radiol 2007 Sep;63(3):351-60. 
(31) Heidenreich A, Bastian PJ, Bellmut J, Bolla M, Joniau S, Mason MD, et al. EAU Guidelines on Prostate Cancer 2012. http://www uroweb org/gls/pdf/08\%20Prostate\%20Cancer_LR\%20March\%2013th\%202012 pdf 2012

(32) Hovels AM, Heesakkers RA, Adang EM, Jager GJ, Strum S, Hoogeveen YL, et al. The diagnostic accuracy of CT and MRI in the staging of pelvic lymph nodes in patients with prostate cancer: a meta-analysis. Clin Radiol 2008 Apr;63(4):387-95.

(33) Gleason DF, Mellinger GT. Prediction of prognosis for prostatic adenocarcinoma by combined histological grading and clinical staging. J Urol 1974 Jan 1974;58-64.

(34) Kvale R, Moller B, Wahlqvist R, Fossa SD, Berner A, Busch C, et al. Concordance between Gleason scores of needle biopsies and radical prostatectomy specimens: a population-based study. BJU Int 2009 Jun;103(12):1647-54.

(35) Humphrey PA. Gleason grading and prognostic factors in carcinoma of the prostate. Mod Pathol 2004 Mar;17(3):292-306.

(36) Bill-Axelson A, Holmberg L, Ruutu M, Garmo H, Stark JR, Busch C, et al. Radical prostatectomy versus watchful waiting in early prostate cancer. N Engl J Med 2011 May 5;364(18):1708-17.

(37) Lilleby W, Torlakovic G, Torlakovic E, Skovlund E, Fossa SD. Prognostic significance of histologic grading in patients with prostate carcinoma who are assessed by the Gleason and World Health Organization grading systems in needle biopsies obtained prior to radiotherapy. Cancer $2001 \mathrm{Jul}$ 15;92(2):311-9.

(38) Balk SP, Ko YJ, Bubley GJ. Biology of prostate-specific antigen. J Clin Oncol 2003 Jan 15;21(2):383-91.

(39) Andriole GL, Crawford ED, Grubb RL, III, Buys SS, Chia D, Church TR, et al. Mortality results from a randomized prostate-cancer screening trial. N Engl J Med 2009 Mar 26;360(13):1310-9.

(40) Thompson IM, Pauler DK, Goodman PJ, Tangen CM, Lucia MS, Parnes HL, et al. Prevalence of prostate cancer among men with a prostate-specific antigen level $<$ or $=4.0 \mathrm{ng}$ per milliliter. N Engl J Med 2004 May 27;350(22):2239-46.

(41) D'Amico AV, Moul JW, Carroll PR, Sun L, Lubeck D, Chen MH. Surrogate end point for prostate cancer-specific mortality after radical prostatectomy or radiation therapy. J Natl Cancer Inst 2003 Sep 17;95(18):1376-83.

(42) Sengupta S, Myers RP, Slezak JM, Bergstralh EJ, Zincke H, Blute ML. Preoperative prostate specific antigen doubling time and velocity are strong and independent predictors of outcomes following radical prostatectomy. J Urol 2005 Dec;174(6):2191-6.

(43) Freedland SJ, Dorey F, Aronson WJ. Preoperative PSA velocity and doubling time do not predict adverse pathologic features or biochemical recurrence after radical prostatectomy. Urology 2001 Mar;57(3):476-80.

(44) Loeb S, Metter EJ, Kan D, Roehl KA, Catalona WJ. Prostate-specific antigen velocity (PSAV) risk count improves the specificity of screening for clinically significant prostate cancer. BJU Int $2012 \mathrm{Feb} ; 109(4): 508-13$. 
(45) Vickers AJ, Till C, Tangen CM, Lilja H, Thompson IM. An empirical evaluation of guidelines on prostate-specific antigen velocity in prostate cancer detection. J Natl Cancer Inst 2011 Mar $16 ; 103(6): 462-9$.

(46) Johannessen DC, Klepp O, Berge V, Lilleby W, Brennhovd B, Angelsen A. Nasjonalt handlingsprogram med retningslinjer

for diagnostikk, behandling og oppfølging av prostatakreft. http://helsedirektoratet no/publikasjoner/nasjonalt-handlingsprogram-med-retningslinjer-for-diagnostikk-behandlingog-oppfolging-av-prostatakreft/Publikasjoner/Prostatakreft pdf 2009

(47) Boccon-Gibod L, Djavan WB, Hammerer P, Hoeltl W, Kattan MW, Prayer-Galetti T, et al. Management of prostate-specific antigen relapse in prostate cancer: a European Consensus. Int J Clin Pract 2004 Apr;58(4):382-90.

(48) Roach M, III, Hanks G, Thames H, Jr., Schellhammer P, Shipley WU, Sokol GH, et al. Defining biochemical failure following radiotherapy with or without hormonal therapy in men with clinically localized prostate cancer: recommendations of the RTOG-ASTRO Phoenix Consensus Conference. Int J Radiat Oncol Biol Phys 2006 Jul 15;65(4):965-74.

(49) D'Amico AV, Whittington R, Malkowicz SB, Schultz D, Blank K, Broderick GA, et al. Biochemical outcome after radical prostatectomy, external beam radiation therapy, or interstitial radiation therapy for clinically localized prostate cancer. JAMA 1998 Sep 16 1998;969-74.

(50) D'Amico AV, Moul J, Carroll PR, Sun L, Lubeck D, Chen MH. Cancer-specific mortality after surgery or radiation for patients with clinically localized prostate cancer managed during the prostate-specific antigen era. J Clin Oncol 2003 Jun 1;21(11):2163-72.

(51) National Comprehensive Cancer Network ${ }^{\circledR}(\mathrm{NCCN})$ guidelines. http://www ncen org/professionals/physician_gls/f_guidelines asp\#prostate 2012

(52) Tosoian JJ, Trock BJ, Landis P, Feng Z, Epstein JI, Partin AW, et al. Active surveillance program for prostate cancer: an update of the Johns Hopkins experience. J Clin Oncol 2011 Jun 1;29(16):2185-90.

(53) Adolfsson J. Watchful waiting and active surveillance: the current position. BJU Int 2008 Jul;102(1):10-4.

(54) Fransson P, Lund JA, Damber JE, Klepp O, Wiklund F, Fossa S, et al. Quality of life in patients with locally advanced prostate cancer given endocrine treatment with or without radiotherapy: 4-year follow-up of SPCG-7/SFUO-3, an open-label, randomised, phase III trial. Lancet Oncol 2009 Apr 2010;370-80.

(55) Widmark A, Klepp O, Solberg A, Damber JE, Angelsen A, Fransson P, et al. Endocrine treatment, with or without radiotherapy, in locally advanced prostate cancer (SPCG-7/SFUO3): an open randomised phase III trial. Lancet 2009 Jan 24;373(9660):301-8.

(56) Bolla M, Van TG, Warde P, Dubois JB, Mirimanoff RO, Storme G, et al. External irradiation with or without long-term androgen suppression for prostate cancer with high metastatic risk: 10-year results of an EORTC randomised study. Lancet Oncol 2010 Nov;11(11):1066-73.

(57) D'Amico AV, Chen MH, Renshaw AA, Loffredo M, Kantoff PW. Androgen suppression and radiation vs radiation alone for prostate cancer: a randomized trial. JAMA 2008 Jan 23;299(3):289-95. 
(58) Horwitz EM, Bae K, Hanks GE, Porter A, Grignon DJ, Brereton HD, et al. Ten-year follow-up of radiation therapy oncology group protocol 92-02: a phase III trial of the duration of elective androgen deprivation in locally advanced prostate cancer. J Clin Oncol 2008 May 20;26(15):2497-504.

(59) D'Amico AV. Risk-based management of prostate cancer. N Engl J Med 2011 Jul 14;365(2):169-71.

(60) Bianco FJ, Jr., Scardino PT, Eastham JA. Radical prostatectomy: long-term cancer control and recovery of sexual and urinary function ("trifecta"). Urology 2005 Nov;66(5 Suppl):83-94.

(61) Bill-Axelson A, Holmberg L, Filen F, Ruutu M, Garmo H, Busch C, et al. Radical prostatectomy versus watchful waiting in localized prostate cancer: the Scandinavian prostate cancer group-4 randomized trial. J Natl Cancer Inst 2008 Aug 20;100(16):1144-54.

(62) Johnstone PA, Ward KC, Goodman M, Assikis V, Petros JA. Radical prostatectomy for clinical T4 prostate cancer. Cancer 2006 Jun 15;106(12):2603-9.

(63) Eastham JA, Kattan MW, Riedel E, Begg CB, Wheeler TM, Gerigk C, et al. Variations among individual surgeons in the rate of positive surgical margins in radical prostatectomy specimens. J Urol 2003 Dec;170(6 Pt 1):2292-5.

(64) Rassweiler J, Frede T, Seemann O, Stock C, Sentker L. Telesurgical laparoscopic radical prostatectomy. Initial experience. Eur Urol 2001 Jul;40(1):75-83.

(65) Binder J, Kramer W. Robotically-assisted laparoscopic radical prostatectomy. BJU Int 2001 Mar;87(4):408-10.

(66) Tewari A, Srivasatava A, Menon M. A prospective comparison of radical retropubic and robot-assisted prostatectomy: experience in one institution. BJU Int 2003 Aug;92(3):205-10.

(67) Agarwal PK, Sammon J, Bhandari A, Dabaja A, Diaz M, Dusik-Fenton S, et al. Safety profile of robot-assisted radical prostatectomy: a standardized report of complications in 3317 patients. Eur Urol 2011 May;59(5):684-98.

(68) Kowalczyk KJ, Levy JM, Caplan CF, Lipsitz SR, Yu HY, Gu X, et al. Temporal national trends of minimally invasive and retropubic radical prostatectomy outcomes from 2003 to 2007: results from the 100\% Medicare sample. Eur Urol 2012 Apr;61(4):803-9.

(69) Marien T, Sankin A, Lepor H. Factors predicting preservation of erectile function in men undergoing open radical retropubic prostatectomy. J Urol 2009 Apr;181(4):1817-22.

(70) Burnett AL, Aus G, Canby-Hagino ED, Cookson MS, D'Amico AV, Dmochowski RR, et al. Erectile function outcome reporting after clinically localized prostate cancer treatment. J Urol 2007 Aug;178(2):597-601.

(71) Levinson AW, Pavlovich CP, Ward NT, Link RE, Mettee LZ, Su LM. Association of surgeon subjective characterization of nerve sparing quality with potency following laparoscopic radical prostatectomy. J Urol 2008 Apr;179(4):1510-4.

(72) Rabbani F, Stapleton AM, Kattan MW, Wheeler TM, Scardino PT. Factors predicting recovery of erections after radical prostatectomy. J Urol 2000 Dec;164(6):1929-34. 
(73) Moskovic DJ, Alphs H, Nelson CJ, Rabbani F, Eastham J, Touijer K, et al. Subjective characterization of nerve sparing predicts recovery of erectile function after radical prostatectomy: defining the utility of a nerve sparing grading system. J Sex Med 2011 Jan;8(1):255-60.

(74) Viani GA, Stefano EJ, Afonso SL. Higher-than-conventional radiation doses in localized prostate cancer treatment: a meta-analysis of randomized, controlled trials. Int J Radiat Oncol Biol Phys 2009 Aug 1;74(5):1405-18.

(75) Harmenberg U, Hamdy FC, Widmark A, Lennernas B, Nilsson S. Curative radiation therapy in prostate cancer. Acta Oncol 2011 Jun;50 Suppl 1:98-103.

(76) Nilsson S, Norlen BJ, Widmark A. A systematic overview of radiation therapy effects in prostate cancer. Acta Oncol 2004;43(4):316-81.

(77) Pilepich MV, Winter K, Lawton CA, Krisch RE, Wolkov HB, Movsas B, et al. Androgen suppression adjuvant to definitive radiotherapy in prostate carcinoma--long-term results of phase III RTOG 85-31. Int J Radiat Oncol Biol Phys 2005 Apr 1;61(5):1285-90.

(78) Zelefsky MJ, Yamada Y, Fuks Z, Zhang Z, Hunt M, Cahlon O, et al. Long-term results of conformal radiotherapy for prostate cancer: impact of dose escalation on biochemical tumor control and distant metastases-free survival outcomes. Int J Radiat Oncol Biol Phys 2008 Jul 15;71(4):1028-33.

(79) Diez P, Vogelius IS, Bentzen SM. A new method for synthesizing radiation dose-response data from multiple trials applied to prostate cancer. Int J Radiat Oncol Biol Phys $2010 \mathrm{Jul}$ 15;77(4):1066-71.

(80) Dearnaley DP, Sydes MR, Graham JD, Aird EG, Bottomley D, Cowan RA, et al. Escalateddose versus standard-dose conformal radiotherapy in prostate cancer: first results from the MRC RT01 randomised controlled trial. Lancet Oncol 2007 Jun;8(6):475-87.

(81) Kupelian P, Kuban D, Thames H, Levy L, Horwitz E, Martinez A, et al. Improved biochemical relapse-free survival with increased external radiation doses in patients with localized prostate cancer: the combined experience of nine institutions in patients treated in 1994 and 1995. Int J Radiat Oncol Biol Phys 2005 Feb 1;61(2):415-9.

(82) Kuban DA, Tucker SL, Dong L, Starkschall G, Huang EH, Cheung MR, et al. Long-term results of the M. D. Anderson randomized dose-escalation trial for prostate cancer. Int J Radiat Oncol Biol Phys 2008 Jan 1;70(1):67-74.

(83) Zietman AL, DeSilvio ML, Slater JD, Rossi CJ, Jr., Miller DW, Adams JA, et al. Comparison of conventional-dose vs high-dose conformal radiation therapy in clinically localized adenocarcinoma of the prostate: a randomized controlled trial. JAMA 2005 Sep 14;294(10):1233-9.

(84) Bolla M, de Reijke TM, Van TG, Van den Bergh AC, Oddens J, Poortmans PM, et al. Duration of androgen suppression in the treatment of prostate cancer. N Engl J Med 2009 Jun $11 ; 360(24): 2516-27$.

(85) Peeters ST, Heemsbergen WD, Koper PC, van Putten WL, Slot A, Dielwart MF, et al. Doseresponse in radiotherapy for localized prostate cancer: results of the Dutch multicenter randomized phase III trial comparing 68 Gy of radiotherapy with 78 Gy. J Clin Oncol 2006 May 1;24(13):1990-6. 
(86) Pinkawa M, Piroth MD, Holy R, Djukic V, Klotz J, Krenkel B, et al. Combination of dose escalation with technological advances (intensity-modulated and image-guided radiotherapy) is not associated with increased morbidity for patients with prostate cancer. Strahlenther Onkol 2011 Aug;187(8):479-84.

(87) Buskirk SJ, Pisansky TM, Atkinson EJ, Schild SE, O'Brien PC, Wolfe JT, et al. Lymph nodepositive prostate cancer: evaluation of the results of the combination of androgen deprivation therapy and radiation therapy. Mayo Clin Proc 2001 Jul;76(7):702-6.

(88) Lawton CA, Bae K, Pilepich M, Hanks G, Shipley W. Long-term treatment sequelae after external beam irradiation with or without hormonal manipulation for adenocarcinoma of the prostate: analysis of radiation therapy oncology group studies 85-31, 86-10, and 92-02. Int $\mathbf{J}$ Radiat Oncol Biol Phys 2008 Feb 1;70(2):437-41.

(89) Roach M, III, DeSilvio M, Lawton C, Uhl V, Machtay M, Seider MJ, et al. Phase III trial comparing whole-pelvic versus prostate-only radiotherapy and neoadjuvant versus adjuvant combined androgen suppression: Radiation Therapy Oncology Group 9413. J Clin Oncol 2003 May 15;21(10):1904-11.

(90) Nomogram. http://nomograms mskcc org/prostate/PreTreatment aspx 2012

(91) Lilleby W, Tafjord G, Raabe NK. Implementation of High-dose-rate Brachytherapy and Androgen Deprivation in Patients with Prostate Cancer. Int J Radiat Oncol Biol Phys 2011 Dec 2.

(92) Nath R, Bongiorni P, Chen Z, Gragnano J, Rockwell S. Dose rate dependence of the relative biological effectiveness of 103Pd for continuous low dose rate irradiation of BA1112 rhabdomyosarcoma cells in vitro relative to acute exposures. Int J Radiat Biol 2005 Sep;81(9):689-99.

(93) Peinemann. Low dose-rate brachytherapy for men with localized PCa. Cochrane Prostatic Diseases and Urologic Cancers Group. New, published in Issue 7, 2011; 2011.

(94) Thompson IM, Jr., Tangen CM, Paradelo J, Lucia MS, Miller G, Troyer D, et al. Adjuvant radiotherapy for pathologically advanced prostate cancer: a randomized clinical trial. JAMA 2006 Nov 15;296(19):2329-35.

(95) Bolla M, van PH, Collette L, van CP, Vekemans K, Da PL, et al. Postoperative radiotherapy after radical prostatectomy: a randomised controlled trial (EORTC trial 22911). Lancet 2005 Aug 13;366(9485):572-8.

(96) Thompson IM, Tangen CM, Paradelo J, Lucia MS, Miller G, Troyer D, et al. Adjuvant radiotherapy for pathological T3N0M0 prostate cancer significantly reduces risk of metastases and improves survival: long-term followup of a randomized clinical trial. J Urol 2009 Mar;181(3):956-62.

(97) King CR, Spiotto MT. Improved outcomes with higher doses for salvage radiotherapy after prostatectomy. Int J Radiat Oncol Biol Phys 2008 May 1;71(1):23-7.

(98) King CR, Kapp DS. Radiotherapy after prostatectomy: is the evidence for dose escalation out there? Int J Radiat Oncol Biol Phys 2008 Jun 1;71(2):346-50. 
(99) Kyrdalen A, Dahl AA, Hernes E, Småstuen MC, Fosså SD. A national study of adverse effects and global quality of life among candidates for curative treatment for prostate cancer. BJU 2012. In press 2012.

(100) Potosky AL, Legler J, Albertsen PC, Stanford JL, Gilliland FD, Hamilton AS, et al. Health outcomes after prostatectomy or radiotherapy for prostate cancer: results from the Prostate Cancer Outcomes Study. J Natl Cancer Inst 2000 Oct 4;92(19):1582-92.

(101) van PH, Collette L, Kirkali Z, Brausi M, Hoekstra W, Newling DW, et al. Quality control of radical prostatectomy: a feasibility study. Eur J Cancer 2001 May;37(7):884-91.

(102) Walsh PC, Partin AW, Epstein JI. Cancer control and quality of life following anatomical radical retropubic prostatectomy: results at 10 years. J Urol 1994 Nov;152(5 Pt 2):1831-6.

(103) Johansson E, Steineck G, Holmberg L, Johansson JE, Nyberg T, Ruutu M, et al. Long-term quality-of-life outcomes after radical prostatectomy or watchful waiting: the Scandinavian Prostate Cancer Group-4 randomised trial. Lancet Oncol 2011 Sep;12(9):891-9.

(104) van der Wielen GJ, Mulhall JP, Incrocci L. Erectile dysfunction after radiotherapy for prostate cancer and radiation dose to the penile structures: a critical review. Radiother Oncol 2007 Aug;84(2):107-13.

(105) Korfage IJ, Essink-Bot ML, Borsboom GJ, Madalinska JB, Kirkels WJ, Habbema JD, et al. Five-year follow-up of health-related quality of life after primary treatment of localized prostate cancer. Int J Cancer 2005 Aug 20;116(2):291-6.

(106) Fransson P, Widmark A. Does one have a sexual life 15 years after external beam radiotherapy for prostate cancer? Prospective patient-reported outcome of sexual function comparison with age-matched controls. Urol Oncol 2011 Mar;29(2):137-44.

(107) Lindau ST, Schumm LP, Laumann EO, Levinson W, O'Muircheartaigh CA, Waite LJ. A study of sexuality and health among older adults in the United States. N Engl J Med 2007 Aug 23;357(8):762-74.

(108) Steinsvik EA, Axcrona K, Dahl AA, Eri LM, Stensvold A, Fossa SD. Can sexual bother after radical prostatectomy be predicted preoperatively? Findings from a prospective national study of the relation between sexual function, activity and bother. BJU Int 2012 May;109(9):136674.

(109) Lehrer S, Cesaretti J, Stone NN, Stock RG. Urinary symptom flare after brachytherapy for prostate cancer is associated with erectile dysfunction and more urinary symptoms before implantation. BJU Int 2006 Nov;98(5):979-81.

(110) Fransson P. Patient-reported lower urinary tract symptoms, urinary incontinence, and quality of life after external beam radiotherapy for localized prostate cancer-- 15 years' follow-up. A comparison with age-matched controls. Acta Oncol 2008;47(5):852-61.

(111) Fransson P, Widmark A. Late side effects unchanged 4-8 years after radiotherapy for prostate carcinoma: a comparison with age-matched controls. Cancer 1999 Feb 1;85(3):678-88.

(112) Brandeis JM, Litwin MS, Burnison CM, Reiter RE. Quality of life outcomes after brachytherapy for early stage prostate cancer. J Urol 2000 Mar;163(3):851-7. 
(113) Litwin MS, Gore JL, Kwan L, Brandeis JM, Lee SP, Withers HR, et al. Quality of life after surgery, external beam irradiation, or brachytherapy for early-stage prostate cancer. Cancer 2007 Jun 1;109(11):2239-47.

(114) Penson DF, Litwin MS. Quality of life after treatment for prostate cancer. Curr Urol Rep 2003 Jun;4(3):185-95.

(115) Murphy GP, Mettlin C, Menck H, Winchester DP, Davidson AM. National patterns of prostate cancer treatment by radical prostatectomy: results of a survey by the American College of Surgeons Commission on Cancer. J Urol 1994 Nov;152(5 Pt 2):1817-9.

(116) Begg CB, Riedel ER, Bach PB, Kattan MW, Schrag D, Warren JL, et al. Variations in morbidity after radical prostatectomy. N Engl J Med 2002 Apr 11;346(15):1138-44.

(117) Andreyev HJ, Wotherspoon A, Denham JW, Hauer-Jensen M. Defining pelvic-radiation disease for the survivorship era. Lancet Oncol 2010 Apr;11(4):310-2.

(118) Wahlgren T, Nilsson S, Lennernas B, Brandberg Y. Promising long-term health-related quality of life after high-dose-rate brachytherapy boost for localized prostate cancer. Int J Radiat Oncol Biol Phys 2007 Nov 1;69(3):662-70.

(119) Zelefsky MJ, Chan H, Hunt M, Yamada Y, Shippy AM, Amols H. Long-term outcome of high dose intensity modulated radiation therapy for patients with clinically localized prostate cancer. J Urol 2006 Oct;176(4 Pt 1):1415-9.

(120) Radbruch L, Strasser F, Elsner F, Goncalves JF, Loge J, Kaasa S, et al. Fatigue in palliative care patients -- an EAPC approach. Palliat Med 2008 Jan;22(1):13-32.

(121) Loge JH, Ekeberg O, Kaasa S. Fatigue in the general Norwegian population: normative data and associations. J Psychosom Res 1998 Jul;45(1):53-65.

(122) Kyrdalen AE, Dahl AA, Hernes E, Cvancarova M, Fossa SD. Fatigue in hormone-naive prostate cancer patients treated with radical prostatectomy or definitive radiotherapy. Prostate Cancer Prostatic Dis 2010 Jun;13(2):144-50.

(123) Wood LJ, Nail LM, Gilster A, Winters KA, Elsea CR. Cancer chemotherapy-related symptoms: evidence to suggest a role for proinflammatory cytokines. Oncol Nurs Forum 2006 May;33(3):535-42.

(124) Argiles JM, Busquets S, Lopez-Soriano FJ. The pivotal role of cytokines in muscle wasting during cancer. Int J Biochem Cell Biol 2005 Oct;37(10):2036-46.

(125) Muscaritoli M, Bossola M, Aversa Z, Bellantone R, Rossi FF. Prevention and treatment of cancer cachexia: new insights into an old problem. Eur J Cancer 2006 Jan;42(1):31-41.

(126) Orre IJ, Murison R, Dahl AA, Ueland T, Aukrust P, Fossa SD. Levels of circulating interleukin-1 receptor antagonist and C-reactive protein in long-term survivors of testicular cancer with chronic cancer-related fatigue. Brain Behav Immun 2009 Aug;23(6):868-74.

(127) Jones CU, Hunt D, McGowan DG, Amin MB, Chetner MP, Bruner DW, et al. Radiotherapy and short-term androgen deprivation for localized prostate cancer. N Engl J Med $2011 \mathrm{Jul}$ $14 ; 365(2): 107-18$. 
(128) Saini A, Berruti A, Cracco C, Sguazzotti E, Porpiglia F, Russo L, et al. Psychological distress in men with prostate cancer receiving adjuvant androgen-deprivation therapy(,). Urol Oncol 2011 Jul 29.

(129) Alibhai SM, Gogov S, Allibhai Z. Long-term side effects of androgen deprivation therapy in men with non-metastatic prostate cancer: a systematic literature review. Crit Rev Oncol Hematol 2006 Dec;60(3):201-15.

(130) Van HM, Garmo H, Holmberg L, Ingelsson E, Bratt O, Bill-Axelson A, et al. Absolute and relative risk of cardiovascular disease in men with prostate cancer: results from the Population-Based PCBaSe Sweden. J Clin Oncol 2010 Jul 20;28(21):3448-56.

(131) van PH, Tombal B. Cardiovascular risk during hormonal treatment in patients with prostate cancer. Cancer Manag Res 2011;3:49-55.

(132) Nguyen PL, Je Y, Schutz FA, Hoffman KE, Hu JC, Parekh A, et al. Association of androgen deprivation therapy with cardiovascular death in patients with prostate cancer: a meta-analysis of randomized trials. JAMA 2011 Dec 7;306(21):2359-66.

(133) Brenner DJ, Curtis RE, Hall EJ, Ron E. Second malignancies in prostate carcinoma patients after radiotherapy compared with surgery. Cancer 2000 Jan 15;88(2):398-406.

(134) Brenner DJ, Hall EJ. Computed tomography--an increasing source of radiation exposure. N Engl J Med 2007 Nov 29;357(22):2277-84.

(135) Sountoulides P, Koletsas N, Kikidakis D, Paschalidis K, Sofikitis N. Secondary malignancies following radiotherapy for prostate cancer. Ther Adv Urol 2010 Jun;2(3):119-25.

(136) Abdel-Wahab M, Reis IM, Hamilton K. Second primary cancer after radiotherapy for prostate cancer--a seer analysis of brachytherapy versus external beam radiotherapy. Int J Radiat Oncol Biol Phys 2008 Sep 1;72(1):58-68.

(137) Sanda MG, Dunn RL, Michalski J, Sandler HM, Northouse L, Hembroff L, et al. Quality of life and satisfaction with outcome among prostate-cancer survivors. N Engl J Med 2008 Mar 20;358(12):1250-61.

(138) Pardo Y, Guedea F, Aguilo F, Fernandez P, Macias V, Marino A, et al. Quality-of-life impact of primary treatments for localized prostate cancer in patients without hormonal treatment. $\mathrm{J}$ Clin Oncol 2010 Nov 1;28(31):4687-96.

(139) Wahlgren T, Brandberg Y, Haggarth L, Hellstrom M, Nilsson S. Health-related quality of life in men after treatment of localized prostate cancer with external beam radiotherapy combined with (192)ir brachytherapy: a prospective study of 93 cases using the EORTC questionnaires QLQ-C30 and QLQ-PR25. Int J Radiat Oncol Biol Phys 2004 Sep 1;60(1):51-9.

(140) Bhatnagar V, Stewart ST, Huynh V, Jorgensen G, Kaplan RM. Estimating the risk of longterm erectile, urinary and bowel symptoms resulting from prostate cancer treatment. Prostate Cancer Prostatic Dis 2006;9(2):136-46.

(141) Joseph KJ, Alvi R, Skarsgard D, Tonita J, Pervez N, Small C, et al. Analysis of health related quality of life (HRQoL) of patients with clinically localized prostate cancer, one year after treatment with external beam radiotherapy (EBRT) alone versus EBRT and high dose rate brachytherapy (HDRBT). Radiat Oncol 2008;3:20. 
(142) Quality of life and pharmacoeconomics in clinical trials. 2nd ed. Philadelphia: Lippincott Williams and Wilkins; 1996. 1996.

(143) Wahlgren T, Levitt S, Kowalski J, Nilsson S, Brandberg Y. Use of the Charlson combined comorbidity index to predict postradiotherapy quality of life for prostate cancer patients. Int $\mathrm{J}$ Radiat Oncol Biol Phys 2011 Nov 15;81(4):997-1004.

(144) Basch E, Iasonos A, McDonough T, Barz A, Culkin A, Kris MG, et al. Patient versus clinician symptom reporting using the National Cancer Institute Common Terminology Criteria for Adverse Events: results of a questionnaire-based study. Lancet Oncol 2006 Nov;7(11):903-9.

(145) Sprangers MA, Cull A, Bjordal K, Groenvold M, Aaronson NK. The European Organization for Research and Treatment of Cancer. Approach to quality of life assessment: guidelines for developing questionnaire modules. EORTC Study Group on Quality of Life. Qual Life Res 1993 Aug;2(4):287-95.

(146) Litwin MS, Hays RD, Fink A, Ganz PA, Leake B, Leach GE, et al. Quality-of-life outcomes in men treated for localized prostate cancer. JAMA 1995 Jan 11;273(2):129-35.

(147) Litwin MS, Hays RD, Fink A, Ganz PA, Leake B, Brook RH. The UCLA Prostate Cancer Index: development, reliability, and validity of a health-related quality of life measure. Med Care 1998 Jul;36(7):1002-12.

(148) Litwin MS. Measuring health related quality of life in men with prostate cancer. J Urol 1994 Nov;152(5 Pt 2):1882-7.

(149) Wei JT, Dunn RL, Litwin MS, Sandler HM, Sanda MG. Development and validation of the expanded prostate cancer index composite (EPIC) for comprehensive assessment of healthrelated quality of life in men with prostate cancer. Urology 2000 Dec 20;56(6):899-905.

(150) Szymanski KM, Wei JT, Dunn RL, Sanda MG. Development and validation of an abbreviated version of the expanded prostate cancer index composite instrument for measuring healthrelated quality of life among prostate cancer survivors. Urology 2010 Nov;76(5):1245-50.

(151) EPIC-clinical practice (CP). http://www bidmc org/CentersandDepartments/Departments/CancerCenter/OurSpecialtyPrograms/ProstateCance rCenter/EPICCP aspx 2012

(152) Malcolm JB, Fabrizio MD, Barone BB, Given RW, Lance RS, Lynch DF, et al. Quality of life after open or robotic prostatectomy, cryoablation or brachytherapy for localized prostate cancer. J Urol 2010 May;183(5):1822-8.

(153) Liang K-Y ZSL. Longitudinal Data Analysis Using Generalized Linear Models. Biometrika 1986;73(1 (Apr. 1986)):13-22.

(154) Burton P, Gurrin L, Sly P. Extending the simple linear regression model to account for correlated responses: an introduction to generalized estimating equations and multi-level mixed modelling. Stat Med 1998 Jun 15;17(11):1261-91.

(155) Clinical practice guidelines: directions for a new program. Field MJ eds, editor. 1990. Washington, DC: National Academy Press, 1990.

Ref Type: Data File 
(156) Baiardini I, Braido F, Bonini M, Compalati E, Canonica GW. Why do doctors and patients not follow guidelines? Curr Opin Allergy Clin Immunol 2009 Jun;9(3):228-33.

(157) Antman EM, Gibbons RJ. Clinical practice guidelines and scientific evidence. JAMA 2009 Jul $8 ; 302(2): 143-4$.

(158) Thomsen I (Chair). AUA Prostate Cancer guidelines 2007. http://www auanet org/content/clinical-practice-guidelines/clinical-guidelines/main-reports/proscan07/content pdf 2007

(159) Damber J-EC. Nationella riktlinjer för prostatacancersjukvård, Medicinskt och hälsoekonomiskt faktadokument. http://www socialstyrelsen se/Lists/Artikelkatalog/Attachments/8946/2007-102-8_20071029 pdf 2012

(160) Shekelle PG, Ortiz E, Rhodes S, Morton SC, Eccles MP, Grimshaw JM, et al. Validity of the Agency for Healthcare Research and Quality clinical practice guidelines: how quickly do guidelines become outdated? JAMA 2001 Sep 26;286(12):1461-7.

(161) Shaneyfelt TM, Centor RM. Reassessment of clinical practice guidelines: go gently into that good night. JAMA 2009 Feb 25;301(8):868-9.

(162) Grol R, Mokkink H, Schellevis F. The effects of peer review in general practice. J R Coll Gen Pract 1988 Jan;38(306):10-3.

(163) Appraisal of Guidelines Research and Evaluation (AGREE). http://www agreetrust org/ 2012

(164) University of Oxford, Center for Evidence Based Medicine (CEBM). http://www cebm net/index aspx?o=1025 2009

(165) Grimshaw JM, Thomas RE, MacLennan G, Fraser C, Ramsay CR, Vale L, et al. Effectiveness and efficiency of guideline dissemination and implementation strategies. Health Technol Assess 2004 Feb;8(6):iii-72.

(166) Forsner T, Hansson J, Brommels M, Wistedt AA, Forsell Y. Implementing clinical guidelines in psychiatry: a qualitative study of perceived facilitators and barriers. BMC Psychiatry 2010;10:8.

(167) Schuster MA, McGlynn EA, Brook RH. How good is the quality of health care in the United States? Milbank Q 1998;76(4):517-63, 509.

(168) Grol R. Improving the quality of medical care: building bridges among professional pride, payer profit, and patient satisfaction. JAMA 2001 Nov 28;286(20):2578-85.

(169) Nilsson S, Cohn-Cedermark G, Wiklund P. Introduction: therapy with curative intent. Acta Oncol 2011 Jun;50 Suppl 1:90-1.

(170) Aus G, Abbou CC, Heidenreich A, Schmid HP, van Poppel H, Wolff JM, et al. EAU Guidelines on Prostate Cancer 2003. http://www uroweb org/fileadmin/tx_eauguidelines/2003/Full/2003_Prostate_Cancer_update pdf 2003

(171) Mykletun A, Dahl AA, O'Leary MP, Fossa SD. Assessment of male sexual function by the Brief Sexual Function Inventory. BJU Int 2006 Feb;97(2):316-23. 
(172) Stensvold A, Dahl AA, Fossa SD, Axcrona K, Lilleby W, Brennhovd B, et al. Clinicians' use of guidelines as illustrated by curative treatment of prostate cancer at a comprehensive cancer center. Acta Oncol 2011 Apr;50(3):408-14.

(173) Stensvold A, Dahl AA, Brennhovd B, Cvancarova M, Fossa SD, Lilleby W, et al. Methods for prospective studies of adverse effects as applied to prostate cancer patients treated with surgery or radiotherapy without hormones. Prostate 2012 May 1;72(6):668-76.

(174) Stensvold A, Dahl AA, Brennhovd B, Smastuen MC, Fossa SD, Lilleby W, et al. Bother problems in prostate cancer patients after curative treatment. Urol Oncol $2012 \mathrm{Feb} 16$.

(175) Bill-Axelson A, Holmberg L, Ruutu M, Haggman M, Andersson SO, Bratell S, et al. Radical prostatectomy versus watchful waiting in early prostate cancer. N Engl J Med 2005 May 12;352(19):1977-84.

(176) Loge JH, Kaasa S. Short form 36 (SF-36) health survey: normative data from the general Norwegian population. Scand J Soc Med 1998 Dec;26(4):250-8.

(177) Ware JE, Jr., Gandek B. Overview of the SF-36 Health Survey and the International Quality of Life Assessment (IQOLA) Project. J Clin Epidemiol 1998 Nov;51(11):903-12.

(178) Gandek B, Ware JE, Aaronson NK, Apolone G, Bjorner JB, Brazier JE, et al. Cross-validation of item selection and scoring for the SF-12 Health Survey in nine countries: results from the IQOLA Project. International Quality of Life Assessment. J Clin Epidemiol 1998 Nov;51(11):1171-8.

(179) Ware J, Jr., Kosinski M, Keller SD. A 12-Item Short-Form Health Survey: construction of scales and preliminary tests of reliability and validity. Med Care 1996 Mar;34(3):220-33.

(180) Zigmond AS, Snaith RP. The hospital anxiety and depression scale. Acta Psychiatr Scand 1983 Jun;67(6):361-70.

(181) Mykletun A, Stordal E, Dahl AA. Hospital Anxiety and Depression (HAD) scale: factor structure, item analyses and internal consistency in a large population. Br J Psychiatry 2001 Dec;179:540-4.

(182) Bjelland I, Dahl AA, Haug TT, Neckelmann D. The validity of the Hospital Anxiety and Depression Scale. An updated literature review. J Psychosom Res 2002 Feb;52(2):69-77.

(183) Chalder T, Berelowitz G, Pawlikowska T, Watts L, Wessely S, Wright D, et al. Development of a fatigue scale. J Psychosom Res 1993;37(2):147-53.

(184) Pawlikowska T, Chalder T, Hirsch SR, Wallace P, Wright DJ, Wessely SC. Population based study of fatigue and psychological distress. BMJ 1994 Mar 19;308(6931):763-6.

(185) Lahey BB. Public health significance of neuroticism. Am Psychol 2009 May;64(4):241-56.

(186) Grov EK, Fossa SD, Bremnes RM, Dahl O, Klepp O, Wist E, et al. The personality trait of neuroticism is strongly associated with long-term morbidity in testicular cancer survivors. Acta Oncol 2009;48(6):842-9.

(187) Tambs K, Sundet JM, Eaves L, Solaas MH, Berg K. Pedigree analysis of Eysenck Personality Questionnaire (EPQ) scores in monozygotic (MZ) twin families. Behav Genet 1991 Jul;21(4):369-82. 
(188) Field A. Discovering Statistics using SPSS Third edition. SAGE; 2009.

(189) Laake P, Hjartåker A, Thelle DS, Veierød MB. Epidemiologiske og kliniske forskningsmetoder. Gyldendal Norsk Forlag AS; 2007.

(190) Benestad HB, Laake P. Forskningsmetode i medisin og biofag. Gyldendal Norsk Forlag AS; 2004.

(191) Rust J, Golombok S. The GRISS: A psychometric scale and profile of sexual dysfunction. Handbook of Sexually-Related Measures. C. M. Davis, W. L. Yarber, R. Bauserman, G. Schreer and S. L. Davis ed. Sage: Thousand Oaks CA; 1998. p. 192-4.

(192) Masterson TA, Cheng L, Boris RS, Koch MO. Open vs. robotic-assisted radical prostatectomy: A single surgeon and pathologist comparison of pathologic and oncologic outcomes. Urol Oncol 2012 Jan 3.

(193) Briganti A, Joniau S, Gontero P, Abdollah F, Passoni NM, Tombal B, et al. Identifying the best candidate for radical prostatectomy among patients with high-risk prostate cancer. Eur Urol 2012 Mar;61(3):584-92.

(194) Ploussard G, Masson-Lecomte A, Beauval JB, Ouzzane A, Bonniol R, Buge F, et al. Radical prostatectomy for high-risk prostate cancer defined by preoperative criteria: oncologic followup in national multicenter study in 813 patients and assessment of easy-to-use prognostic substratification. Urology 2011 Sep;78(3):607-13.

(195) Woolf SH, Grol R, Hutchinson A, Eccles M, Grimshaw J. Clinical guidelines: potential benefits, limitations, and harms of clinical guidelines. BMJ 1999 Feb 20;318(7182):527-30.

(196) Grol R. Successes and failures in the implementation of evidence-based guidelines for clinical practice. Med Care 2001 Aug;39(8 Suppl 2):II46-II54.

(197) Karnes RJ, Hatano T, Blute ML, Myers RP. Radical prostatectomy for high-risk prostate cancer. Jpn J Clin Oncol 2010 Jan;40(1):3-9.

(198) Ficarra V, Novara G, Artibani W, Cestari A, Galfano A, Graefen M, et al. Retropubic, laparoscopic, and robot-assisted radical prostatectomy: a systematic review and cumulative analysis of comparative studies. Eur Urol 2009 May;55(5):1037-63.

(199) Hautmann RE, Sauter TW, Wenderoth UK. Radical retropubic prostatectomy: morbidity and urinary continence in 418 consecutive cases. Urology 1994 Feb;43(2 Suppl):47-51.

(200) Steinsvik EA, Fossa SD, Axcrona K, Fransson P, Widmark A, Dahl AA. Do perceptions of adverse events differ between patients and physicians? Findings from a randomized, controlled trial of radical treatment for prostate cancer. J Urol 2010 Aug;184(2):525-31.

(201) Litwin MS, Lubeck DP, Henning JM, Carroll PR. Differences in urologist and patient assessments of health related quality of life in men with prostate cancer: results of the CaPSURE database. J Urol 1998 Jun;159(6):1988-92.

(202) Fowler FJ, Jr., Barry MJ, Lu-Yao G, Roman A, Wasson J, Wennberg JE. Patient-reported complications and follow-up treatment after radical prostatectomy. The National Medicare Experience: 1988-1990 (updated June 1993). Urology 1993 Dec;42(6):622-9. 
(203) Talcott JA, Rieker P, Propert KJ, Clark JA, Wishnow KI, Loughlin KR, et al. Patient-reported impotence and incontinence after nerve-sparing radical prostatectomy. J Natl Cancer Inst 1997 Aug 6;89(15):1117-23.

(204) Karlsdottir A, Muren LP, Wentzel-Larsen T, Johannessen DC, Haukaas SA, Halvorsen OJ, et al. Outcome in intermediate or high risk prostate cancer patients receiving radiation dose and hormone therapy. Acta Oncol 2009;48(6):874-81.

(205) Gore JL, Gollapudi K, Bergman J, Kwan L, Krupski TL, Litwin MS. Correlates of bother following treatment for clinically localized prostate cancer. J Urol 2010 Oct;184(4):1309-15.

(206) Litwin MS, Flanders SC, Pasta DJ, Stoddard ML, Lubeck DP, Henning JM. Sexual function and bother after radical prostatectomy or radiation for prostate cancer: multivariate quality-oflife analysis from CaPSURE. Cancer of the Prostate Strategic Urologic Research Endeavor. Urology 1999 Sep;54(3):503-8.

(207) Talcott JA, Rieker P, Clark JA, Propert KJ, Weeks JC, Beard CJ, et al. Patient-reported symptoms after primary therapy for early prostate cancer: results of a prospective cohort study. J Clin Oncol 1998 Jan;16(1):275-83.

(208) Bacon CG, Giovannucci E, Testa M, Glass TA, Kawachi I. The association of treatmentrelated symptoms with quality-of-life outcomes for localized prostate carcinoma patients. Cancer 2002 Feb 1;94(3):862-71.

(209) Sprangers MA, Schwartz CE. Integrating response shift into health-related quality of life research: a theoretical model. Soc Sci Med 1999 Jun;48(11):1507-15.

(210) Block CA, Erickson B, Carney-Doebbling C, Gordon S, Fallon B, Konety BR. Personality, treatment choice and satisfaction in patients with localized prostate cancer. Int J Urol 2007 Nov;14(11):1013-8.

(211) Aarts MJ, Mols F, Thong MS, Louwman MW, Coebergh JW, van de Poll-Franse LV. Longterm prostate cancer survivors with low socioeconomic status reported worse mental healthrelated quality of life in a population-based study. Urology 2010 Nov;76(5):1224-30.

(212) Weber BA, Roberts BL, Mills TL, Chumbler NR, Algood CB. Physical and emotional predictors of depression after radical prostatectomy. Am J Mens Health 2008 Jun;2(2):165-71.

(213) Warde P, Mason M, Ding K, Kirkbride P, Brundage M, Cowan R, et al. Combined androgen deprivation therapy and radiation therapy for locally advanced prostate cancer: a randomised, phase 3 trial. Lancet 2011 Dec 17;378(9809):2104-11.

(214) Wooten JM. Drug-induced sexual problems. South Med J 2008 Nov;101(11):1092-3. 
Appendix 



\title{
UCLA Prostatakreft index (UCLA-PCI) med tilleggsspørsmål (SF-12 versjon)
}

\author{
Registreringsskjema
}

Pasient nr:

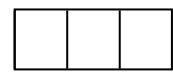

(Fylles ut av KKF)

Dato for utfylling:

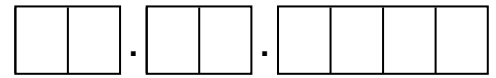

Navnelapp

\section{Kryss av for behandling}

$\square$ Radikal prostatektomi

$\square$ Kryoterapi

$\square$ Strålebehandling uten hormoner

$\square$ Strålebehandling med hormoner

$\square$ Strålebehandling v/ N+ med hormoner

$\square$ Brachyterapi + ekstern strålebehandling uten hormoner

$\square$ Brachyterapi + ekstern strålebehandling med hormoner

\section{Signatur av lege}

Utfylt skjema fra lege og pasient sendes samlet til: Kontor for klinisk forskning, v/ Bente Kvisgaard 


\section{UCLA Prostatakreft index (UCLA-PCI) med tilleggsspørsmål (SF-12 versjon)}

\section{Pasient nr:}

\section{Dato for utfylling:}
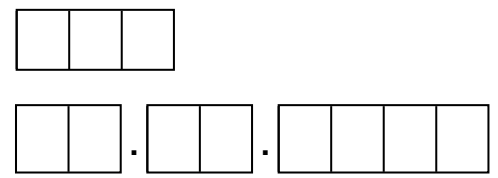

Hensikten med dette spørreskjemaet er å få rede på din helse generelt og hvordan din prostatakreft og behandling for den påvirker din livskvalitet.

Vær snill å lese hvert spørsmål nøye før du svarer. Hvis du er usikker på hva du skal svare på et spørsmål, så svar så godt du kan. Husk at det er ingen riktige eller gale svar.

Dine svar på dette spørreskjemaet vil bli behandlet strengt konfidensielt, og de vil bare bli brukt til forskning. Informasjonen du gir vil bli bearbeidet sammen med svarene fra andre pasienter som også fyller ut skjemaet, slik at det ikke blir mulig å finne tilbake til svarene fra enkeltpersoner.

Spørreskjemaet er en norsk oversettelse av et skjema som er mye brukt internasjonalt, noe som gjør at våre behandlingsresultater kan sammenlignes med resultatene i andre land. Spørsmålene skal stilles til pasienter som gjennomgår flere ulike behandlinger, og noen spørsmål er derfor ikke aktuelle for deg. Vi ber deg likevel ta deg tid til å fylle ut skjemaet fullstendig.

\section{Utfylling av Teleform skjema}

1. Bruk bare blå eller sort kulepenn (ikke blyant)

2. Kryss innenfor rutene: $\mathrm{X}$

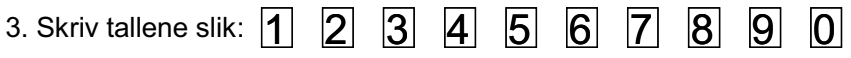

4. Skjemaet må ikke brettes (gir streker i skjemaet ved skanning) 


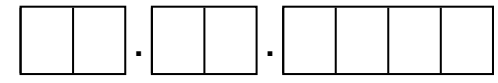

1. Hvilke av følgende passer best på ditt nåværende forhold?

$\square$ Bor med kone eller samboer

$\square$ Er i et fast forhold, men bor ikke sammen

$\square$ Er ikke i noe fast forhold

2. Hvor mye utdanning har du gjennomført?

$\square$ Grunnskole eller mindre

$\square$ Noe videregående eller yrkesskole

$\square$ Gjennomført videregående eller yrkesskole

$\square$ Noe på høgskolenivå

$\square$ Gjennomført høgskole

$\square$ Gjennomført universitetsutdannelse

3. Har du eller har du hatt noen av følgende sykdommer eller tilstander?
a) Sukkersyke (diabetes)
$\square \mathrm{Ja} \quad \square \mathrm{Nei}$
b) Hjerteinfarkt, hjertekrampe (angina)
$\square \mathrm{Ja} \quad \square \mathrm{Nei}$
c) Hjerneslag
$\square \mathrm{Ja} \quad \square \mathrm{Nei}$
d) Amputasjon
$\square \mathrm{Ja} \quad \square \mathrm{Nei}$
e) Dårlig blodforsyning til beina
$\square \mathrm{Ja} \quad \square \mathrm{Nei}$
f) Astma, kronisk bronkitt, pusteproblemer
$\square \mathrm{Ja} \quad \square \mathrm{Nei}$
g) Magesår, irritabel tarm
$\square \mathrm{Ja} \quad \square \mathrm{Nei}$
h) Nyresykdom
$\square \mathrm{Ja} \quad \square \mathrm{Nei}$
i) Alvorlig depresjon
$\square \mathrm{Ja} \quad \square \mathrm{Nei}$
j) Krampeanfall
$\square \mathrm{Ja} \quad \square \mathrm{Nei}$
k) Alkoholproblemer
$\square \mathrm{Ja} \quad \square \mathrm{Nei}$
I) Stoffproblemer
$\square \mathrm{Ja} \quad \square \mathrm{Nei}$
m) Tidligere sigarettrøyker
$\square \mathrm{Ja} \quad \square \mathrm{Nei}$
n) Nåværende sigarettrøyker
$\square \mathrm{Ja} \quad \square \mathrm{Nei}$

4. Er du for tiden i inntektsgivende arbeid?

$\square$ Ja, fulltid

$\square$ Ja, deltid

$\square$ Nei, men søker jobber

$\square$ Nei, pensjonert

$\square$ Nei, sykmeldt eller på attføring

$\square$ Nei, uføretrygdet 
Dato for utfylling:
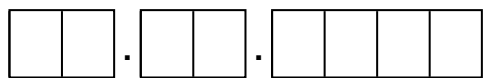

Spørsmålene nedenfor dreier seg om hvordan du vanligvis opptrer, føler og handler. Vennligst kryss av $₫$ for enten Ja eller Nei. Svar hurtig og ikke tenk for lenge over den nøyaktige meningen med hvert spørsmål.

1. Er du forholdsvis livlig? $\quad \square \mathrm{Ja} \quad \square$ Nei

2. Ville du bli oppskaket av å se et barn eller et dyr lide? $\quad \square$ Ja $\quad \square$ Nei

3. Liker du å treffe nye mennesker? $\quad \square \mathrm{Ja} \quad \square \mathrm{Nei}$

4. Blir dine følelser lett såret? $\quad \square \mathrm{Ja} \quad \square \mathrm{Nei}$

5. Hender det ofte at du "går trøtt"? $\quad \square$ Ja $\quad \square$ Nei

6. Liker du å spille andre et puss som av og til kan såre dem? $\quad \square \mathrm{Ja} \quad \square$ Nei

7. Er du ofte bekymret? $\quad \square \mathrm{Ja} \quad \square$ Nei

8. Er gode manerer og renslighet viktig for deg? $\quad \square \mathrm{Ja} \quad \square$ Nei

9. Bekymrer du deg for at fryktelige ting kan skje? $\quad \square$ Ja $\quad \square$ Nei

10. Tar du vanligvis selv det første skrittet for å få nye venner? $\quad \square \mathrm{Ja} \quad \square$ Nei

11. Er du for det meste stille når du er sammen med andre? $\quad \square$ Ja $\quad \square$ Nei

12. Liker du å komme til avtaler i god tid? $\quad \square \mathrm{Ja} \quad \square$ Nei

13. Har du ofte følt deg trøtt og giddesløs uten grunn? $\quad \square$ Ja $\quad \square$ Nei

14. Er det mange mennesker som forsøker å unngå deg? $\quad \square$ Ja $\quad \square$ Nei

15. Klarer du å holde fart i et selskap? $\quad \square$ Ja $\quad \square$ Nei

16. Bekymrer du deg lenge etter en pinlig opplevelse? $\quad \square$ Ja $\quad \square$ Nei

17. Liker du å ha masse liv og røre rundt deg? $\quad \square$ Ja $\quad \square$ Nei

18. Forteller folk deg en masse løgner? $\quad \square \mathrm{Ja} \quad \square$ Nei 
Dato for utfylling:
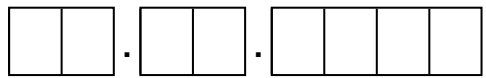

Kontroll mnd.:

Dette spørreskjemaet er utformet for å hjelpe oss til å forstå hvordan du føler deg. Les hvert utsagn og sett kryss $\square$ i ruten som best beskriver dine følelser den siste uka. Fundér ikke for lenge på ditt svar; din umiddelbare reaksjon på hvert spørsmål er sannsynligvis riktigere enn et svar som du har tenkt lenge på.

1. Jeg er nervøs eller anspent

$\square$ For det meste

$\square$ Ofte

$\square$ Noen ganger

$\square$ Ikke i det hele tatt

2. Jeg gleder meg fremdeles over ting jeg pleide å glede meg over

$\square$ Avgjort like mye

$\square$ Ikke fullt så mye

$\square$ Bare lite grann

$\square$ Ikke i det hele tatt

3. Jeg har en urofølelse som om noe forferdelig kommer til å skje

$\square$ Helt sikkert og svært ille

$\square$ Ja, men ikke så veldig ille

$\square$ Litt ille, men det bekymrer meg ikke så mye

$\square$ Ikke i det hele tatt

4. Jeg kan le og se det morsomme i situasjoner

$\square$ Like mye som jeg alltid har gjort

$\square$ Ikke like mye nå som før

$\square$ Avgjort ikke så mye nå som før

Ikke i det hele tatt

\section{Jeg har hodet fullt av bekymringer}

$\square$ Veldig ofte

$\square$ Ganske ofte

$\square$ Av og til

$\square$ En gang i blant

6. Jeg er i godt humør

$\square$ Aldri
$\square$ Noen ganger
$\square$ Ganske ofte
$\square$ For det meste

7. Jeg kan sitte $i$ fred og ro og kjenne meg avslappet

$\square$ Ja, helt klart
$\square$ Vanligvis
$\square$ Ikke så ofte
$\square$ Ikke i det hele tatt

8. Jeg føler meg som om alt går langsommere

$\square$ Nesten hele tiden

$\square$ Svært ofte

$\square$ Fra tid til annen

$\square$ Ikke i det hele tatt

9. Jeg føler meg urolig som om jeg har "sommerfugler" i magen

$\square$ Ikke i det hele tatt

$\square$ Fra tid til annen

$\square$ Ganske ofte

$\square$ Svært ofte

10. Jeg har sluttet å bry meg om hvordan jeg ser ut $\square$ Ja, helt klart

$\square$ Jeg bryr meg ikke så mye som jeg burde

$\square$ Det kan nok hende jeg ikke bryr meg nok

$\square$ Jeg bryr meg om utseendet like mye som jeg allid har gjort

11. Jeg føler meg rastløs som om jeg stadig må være $\mathrm{i}$ aktivitet

$\square$ Uten tvil svært mye

$\square$ Ganske mye

$\square$ Ikke så veldig mye

$\square$ Ikke i det hele tatt

12. Jeg ser med glede frem til hendelser og ting

$\square$ Like mye som jeg alltid har gjort

$\square$ Heller mindre enn jeg pleier

$\square$ Avgjort mindre enn jeg pleier

$\square$ Nesten ikke i det hele tatt

13. Jeg kan plutselig få en følelse av panikk
$\square$ Uten tvil svært ofte
$\square$ Svært ofte
$\square$ Ikke så veldig ofte
$\square$ Ikke i det hele tatt

14. Jeg kan glede meg over en god bok eller et radio eller et TVprogram

$\square$ Ofte

$\square$ Fra tid til annen

$\square$ Ikke så ofte

Svært sjelden 


\section{UCLA-PCI \\ Fatigue (tretthet)}

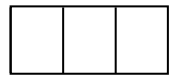

Dato for utfylling:
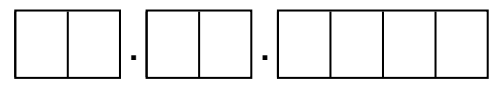

Kontroll mnd.:

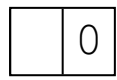

Vi vil gjerne vite om du har følt deg sliten, svak eller i mangel av overskudd den siste måneden. Vennligst besvar ALLE spørsmålene ved å krysse av $\square$ for det svaret du synes passer best for deg. Vi ønsker at du besvarer alle spørsmålene selv om du ikke har hatt slike problemer. Vi spør om hvordan du har følt deg i det siste og ikke om hvordan du følte deg for lenge siden. Hvis du har følt deg sliten lenge, ber vi om at du sammenlikner deg med hvordan du følte deg sist du var bra. (Ett kryss på hver linje)

1. Har du problemer med at du føler deg sliten?

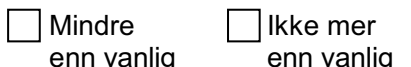

enn vanlig enn vanlig
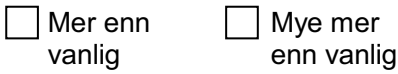

2. Trenger du mer hvile?

3. Føler du deg søvnig eller døsig?

$\square$ Nei, mindre
enn vanlig

$\square$ Ikke mer
enn vanlig
$\square$ Mer enn
vanlig

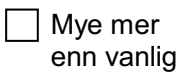

$\square$ Mindre
enn vanlig

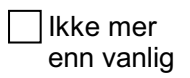
$\square$ Mer enn vanlig

Mye mer enn vanlig

4. Har du problemer med å komme igang med ting?

$\square$ Mindre
enn vanlig

$\square$ Ikke mer
enn vanlig
Mer enn vanlig

Mye mer enn vanlig

5. Mangler du overskudd?

$\square$ Ikke i det
hele tatt

$\square$ Ikke mer
enn vanlig
Mer enn vanlig

Mye mer enn vanlig

6. Har du redusert styrke $i$ musklene dine?

$\square$ Ikke i det
hele tatt

$\square$ Ikke mer
enn vanlig
Mer enn vanlig

Mye mer enn vanlig

7. Føler du deg svak?

$\square$ Mindre
enn vanlig

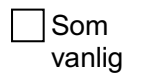
$\square$ Mer enn vanlig
$\square$ Mye mer enn vanlig

8. Har du vansker med å konsentrere deg?

$\square$ Mindre
enn vanlig

$\square$ Som<smiles>CCCCCCCC1CCC1</smiles>

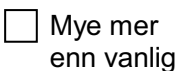

9. Forsnakker du deg $\mathrm{i}$ samtaler?

$\square$ Mindre
enn vanlig
$\square$ Mindre
enn vanlig
$\square$ Bedre enn
vanlig

$\square$ lkke mer
enn vanlig
$\square$ lkke mer
enn vanlig
$\square$ lkke verre
enn vanlig

$\square$ Mer enn
vanlig
$\square$ Mer enn
vanlig
$\square$ Verre enn
vanlig

12. Hvis du føler deg sliten for tiden, omtrent hvor lenge har det vart?

$$
\square \text { Mindre enn en uke } \square \text { Mindre enn tre }
$$

Mellom tre og seks måneder
Seks måneder eller mer

13. Hvis du føler deg sliten for tiden, omtrent hvor mye av tiden kjenner du det?

$\square 25 \%$ av tiden
$50 \%$ av tiden
$75 \%$ av tiden

$\square$ Hele tiden 
Dato for utfylling:
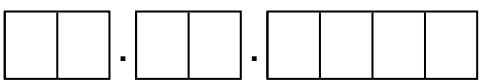

De første spørsmålene er om hvordan du ser på din egen helse, BADDE RELATERT og IKKE RELATERT til din prostatakreft. Vi er klar over at andre sykdommer som du kan ha i tillegg til din prostatakreft kan påvirke svarene dine.

Hvert spørsmål skal besvares ved å sette kryss $\square$ i ruten for det tallet som passer best for deg (bare ett kryss). Hvis du er usikker på hva du skal svare, vennligst svar så godt du kan.

1. Stort sett, vil du si at din helse er:
$\square$ Utmerket
$\square$ Meget god
God
Nokså god
Dårlig

De neste spørsmålene handler om aktiviteter som du kanskje utfører i løpet av en vanlig dag. Er din helse slik at den begrenser deg i utførelsen av disse aktivitetene nå? Hvis ja, hvor mye?

2. Moderate aktiviteter som å flytte et bord, støvsuge, gå en tur eller drive med hagearbeid
$\square$ Ja, begrenser meg mye
$\square$ Ja, begrenser meg litt
Nei, begrenser meg ikke i det hele tatt

3. Gå opp trappen flere etasjer

$\square$ Ja, begrenser meg mye

$\square$ Ja, begrenser meg litt

Nei, begrenser meg ikke i det hele tatt

I løpet av den siste uken, har du hatt noen av følgende problemer $\mathbf{i}$ ditt arbeid eller $\mathbf{i}$ andre av dine gjøremål på grunn av din fysiske helse?

4. Du har utrettet mindre enn du hadde ønsket $\quad \square$ Ja $\square$ Nei

5. Du har vært hindret i visse typer arbeid eller andre gjøremål $\quad \square$ Ja $\square$ Nei

I løpet av den siste uken, har du hatt følesesmessige problemer som har ført til vanskeligheter i ditt arbeid eller $i$ andre av dine daglige gjøremål (f.eks. fordi du har følt deg deprimert eller engstelig)?

6. Du har utrettet mindre enn du hadde ønsket $\quad \square$ Ja $\square$ Nei

7. Du har utført arbeidet eller andre gjøremål mindre grundig enn vanlig $\square$ Ja $\square$ Nei 
8. I løpet av den siste uken, hvor mye har smerter påvirket ditt vanlige arbeid (gjelder både arbeid utenfor hjemmet og husarbeid)?

Ikke i det hele tatt

$\square$ Litt

$\square$ Endel

$\square$ Mye

$\square$ Svært mye

De neste spørsmålene handler om hvordan du har følt deg og hvordan du har hatt det den siste uken. For hvert spørsmål, vennligst velg det svaralternativet som best beskriver din situasjon.

\section{Hvor ofte i løpet av den siste uken?}

9. Har du følt deg rolig og harmonisk?

$\square$ Hele tiden

$\square$ Nesten hele tiden

$\square$ Mye av tiden

$\square$ En del av tiden

$\square$ Litt av tiden

$\square$ Ikke i det hele tatt

10. Har du følt deg full av tiltakslyst?

$\square$ Hele tiden

$\square$ Nesten hele tiden

$\square$ Mye av tiden

$\square$ En del av tiden

$\square$ Litt av tiden

$\square$ Ikke i det hele tatt

11. Har du følt deg nedfor og trist?

$\square$ Hele tiden

$\square$ Nesten hele tiden

$\square$ Mye av tiden

$\square$ En del av tiden

$\square$ Litt av tiden

$\square$ lkke i det hele tatt

12. I løpet av den siste uken, hvor mye av tiden har din fysiske helse eller følelsesmessige problemer påvirket din sosiale omgang (som det å besøke venner, slektninger osv.)?

$\square$ Hele tiden

$\square$ Mesteparten av tiden

$\square$ En del av tiden

$\square$ Litt av tiden

$\square$ lkke i det hele tatt 
Dette avsnittet omhandler din urinfunksjon. Det er kun situasjonen de siste 4 ukene du skal ta i betraktning.

13. Hvor ofte har du hatt urinlekkasje i løpet av de siste 4 ukene?

$\square$ Hver dag

$\square$ Omtrent en gang i uken

$\square$ Sjeldnere enn en gang i uken

$\square$ Aldri

14. Hvordan vil du beskrive din kontroll over blæretømmingen i løpet av de siste 4 ukene?

$\square$ Total manglende kontroll (betydelig urinlekkasje)

$\square$ Hyppig urinlekkasje

$\square$ Dråpelekkasje av og til

$\square$ Ingen lekkasje (full kontroll)

15. Hvor mange trusinnlegg, bind eller bleier har du vanligvis brukt pr. dag for lekkasje i løpet av de siste 4 ukene?

$\square$ Tre eller flere per dag

$\square$ En - to per dag

$\square$ Ingen

16. Hvor stort problem har hver av de følgende vært for deg?

a) Urinlekkasje evt. med våte benklær

$\square$ Ikke noe problem

$\square$ Veldig lite problem

$\square$ Lite problem

$\square$ Moderat problem

$\square$ Stort problem

b) Urinlekkasje som forstyrrer seksuell aktivitet

$\square$ Ikke noe problem

$\square$ Veldig lite problem

$\square$ Lite problem

$\square$ Moderat problem

$\square$ Stort problem

17. Hvor stort problem har du totalt sett hatt med urinfunksjonen de siste 4 ukene?

$\square$ Ikke noe problem

$\square$ Veldig lite problem

$\square$ Lite problem

$\square$ Moderat problem

$\square$ Stort problem 
18. Har du iløpet av de siste 4 ukene måttet skynde deg på toalettet pga. plutselig, kraftig vannlatingstrang?

$\square$ Aldri

$\square$ Av og til (mindre enn en tredjedel av tiden)

$\square$ Noen ganger (i omtrent halvparten av tiden)

$\square$ Oftest (mer enn to tredjedeler av tiden)

$\square$ Alltid

19. Har du hatt urinlekkasje før du har kommet fram til toalettet?

Aldri

$\square$ Av og til (mindre enn en tredjedel av tiden)

$\square$ Noen ganger (i omtrent halvparten av tiden)

$\square$ Oftest (mer enn to tredjedeler av tiden)

Alltid

20. Har du hatt urinlekkasje når du hoster eller nyser?

$\square$ Aldri

$\square$ Av og til (mindre enn en tredjedel av tiden)

Noen ganger (i omtrent halvparten av tiden)

$\square$ Oftest (mer enn to tredjedeler av tiden)

$\square$ Alltid

21. Har det hendt at du har lekket uten noen spesiell grunn og uten at du har følt vannlatingstrang?

$\square$ Aldri

$\square$ Av og til (mindre enn en tredjedel av tiden)

$\square$ Noen ganger (i omtrent halvparten av tiden)

$\square$ Oftest (mer enn to tredjedeler av tiden)

$\square$ Alltid

22. Har du hatt urinlekkasje mens du sover?

$\square$ Aldri

Av og til (mindre enn en tredjedel av tiden)

$\checkmark$ Noen ganger (i omtrent halvparten av tiden)

$\square$ Oftest (mer enn to tredjedeler av tiden)

$\square$ Alltid

23. Hvor ofte har du hatt en mindre urinlekkasje i trusen i løpet av de første minuttene etter at du har avsluttet vannlating?

$\square$ Aldri

Av og til (mindre enn en tredjedel av tiden)

$\checkmark$ Noen ganger (i omtrent halvparten av tiden)

$\square$ Oftest (mer enn to tredjedeler av tiden)

Alltid 
24. Tar det tid før urinen kommer ved vannlating?

$\square$ Aldri

$\square$ Av og til (mindre enn en tredjedel av tiden)

$\square$ Noen ganger (i omtrent halvparten av tiden)

$\square$ Oftest (mer enn to tredjedeler av tiden)

$\square$ Alltid

25. Må du presse eller trykke for å tømme urinblæren?

$\square$ Aldri

$\square$ Av og til (mindre enn en tredjedel av tiden)

$\square$ Noen ganger (i omtrent halvparten av tiden)

$\square$ Oftest (mer enn to tredjedeler av tiden)

$\square$ Alltid

26. Hvordan vil du beskrive kraften på strålen ved vannlating?

$\square$ Aldri redusert

$\square$ Av og til redusert (mindre enn en tredjedel av tiden)

$\square$ Noen ganger redusert (i omtrent halvparten av tiden)

$\square$ Oftest redusert (mer enn to tredjedeler av tiden)

$\square$ Alltid redusert

27. Hender det at urinstrålen stopper opp og starter igjen under vannlating?

$\square$ Aldri

$\square$ Av og til (mindre enn en tredjedel av tiden)

$\square$ Noen ganger (i omtrent halvparten av tiden)

$\square$ Oftest (mer enn to tredjedeler av tiden)

$\square$ Altid

28. Hvor ofte har du følt at blæren er ufullstendig tømt ved vannlating?

$\square$ Aldri

$\square$ Av og til (mindre enn en tredjedel av tiden)

$\square$ Noen ganger (i omtrent halvparten av tiden)

$\square$ Oftest (mer enn to tredjedeler av tiden)

$\square$ Altid

29. Hvor ofte må du late vannet om dagen?

$\square$ Hver time

$\square$ Annenhver time

$\square$ Tredjehver time

Fjerdehver time eller sjeldnere 
30. Hvor mange ganger må du stå opp om natten for å late vannet i gjennomsnitt?

$\square$ Aldri

$\square$ En gang

$\square$ To ganger

$\square$ Tre ganger

$\square$ Fire eller flere ganger

31. Har du hatt svie eller smerte i forbindelse med vannlating i løpet av de siste 4 ukene?

$\square$ lkke i det hele tatt

$\square$ Sjeldnere enn en gang i uken

$\square$ Omtrent en gang i uken

$\square$ Hver dag

32. Har du hatt blod i urinen i løpet av de siste 4 ukene?

$\square$ Ikke i det hele tatt

$\square$ Sjeldnere enn en gang i uken

$\square$ Omtrent en gang i uken

$\square$ Hver dag

33. Hvis du resten av livet måtte leve med de vannlatingsproblemene du har nå, hvordan ville du føle det?

$\square$ Være meget godt fornøyd

$\square$ Være fornøyd

$\square$ Være for det meste tilfreds

$\square$ Ha blandete følelser

$\square$ Være for det meste utilfreds

$\square$ Være misfornøyd

$\square$ Ha det forferdelig 


\section{Avføringsfunksjon}

Dette avsnittet omhandler dine avføringsvaner og magesmerter. Det er kun situasjonen de siste 4 ukene du skal ta i betraktning.

34. Hvor ofte har du hatt plutselig, kraftig avføringstrang (følt at du skulle ha avføring uten at det kom noe) i løpet av de siste 4 ukene?

$\square$ Mer enn en gang per dag

$\square$ Omtrent en gang per dag

Mer enn en gang i uken

$\square$ Omtrent en gang i uken

$\square$ Sjelden eller aldri

35. Hvor ofte har du hatt uvanlig tynn avføring eller diaré i løpet av de siste 4 ukene?

$\square$ Aldri

$\square$ Sjelden

$\square$ Omtrent halvparten av tiden

$\square$ Vanligvis

$\square$ Alltid

36. Hvor store plager har du hatt med avføring i løpet av de siste 4 ukene?

$\square$ Store plager

$\square$ Moderate plager

$\square$ Litt plager

$\square$ Ingen plager

37. Hvor ofte har du hatt krampaktige smerter i magen eller i underlivet i løpet av de siste 4 ukene?

Flere ganger om dagen

Omtrent en gang per dag

Flere ganger i uken

Omtrent en gang i uken

Omtrent en gang denne måneden

Sjelden eller aldri

38. Samlet sett, hvor stort problem har avføringsfunksjonen vært for deg i løpet av de siste 4 ukene?

$\square$ Stort problem

Moderat problem

$\square$ Lite problem

$\square$ Veldig lite problem

lkke noe problem

39. Hvor ofte har du hatt blod i avføringen i løpet av de siste 4 ukene?

$\square$ Hver dag

Omtrent en gang i uken

Sjeldnere enn en gang i uken

Ikke i det hele tatt 
40. Hvor ofte har du hatt slim i avføringen i løpet av de siste 4 ukene?

$\square$ Hver dag

$\square$ Omtrent en gang i uken

$\square$ Sjeldnere enn en gang i uken

$\square$ Ikke i det hele tatt

41. Hvor ofte har du hatt ufrivillig lekkasje av avføring i løpet av de siste 4 ukene?

$\square$ Hver dag

$\square$ Omtrent en gang i uken

$\square$ Sjeldnere enn en gang i uken

$\square$ lkke i det hele tatt

42. Hvor mange truseinnlegg, bind eller bleier for voksne har du vanligvis brukt per dag for avføringslekkasje i løpet av de siste 4 ukene?

$\square$ Tre eller flere per dag

$\square$ En - to per dag

$\square$ Ingen

43. Har ditt avføringsproblem medført at du har måttet planlegge dine toalettbesøk i løpet av de siste 4 ukene?

$\square$ Hver dag

Omtrent en gang i uken

Sjeldnere enn en gang i uken

$\square$ Ikke i det hele tatt

44. Har du vært plaget av at du ventet det skulle komme luft, men så kom det i stedet litt avføring i løpet av de siste 4 ukene?

$\square$ Hver dag

Omtrent en gang i uken

Sjeldnere enn en gang i uken

$\square$ lkke i det hele tatt

45. Hvis du resten av livet måtte leve med de avføringsproblemene du har nå, hvordan ville du føle det?

$\square$ Være meget godt fornøyd

$\square$ Være fornøyd

$\square$ Være for det meste tilfreds

$\square$ Ha blandete følelser

$\square$ Være for det meste utilfreds

Være misfornøyd

$\square$ Ha det forferdelig 
Det neste avsnittet om seksualfunksjon inneholder mange spørsmål av personlig karakter. Vi minner om at svarene på dette spørreskjemaet vil bli behandlet konfidensielt og vil bare bli brukt til forskningsformål: Vær snill å svare så ærlig som du kan om de siste 4 ukene.

46. Hvordan vil du gradere dine evner vedrørende $a, b$ og c nedenfor i løpet av de siste 4 ukene?

a) Grad av seksuell interesse (lyst)

$\square$ Svært dårlig

$\square$ Dårlig

$\square$ Rimelig

$\square$ God

$\square$ Svært god

b) Evne til å få ereksjon (reisning)

$\square$ Svært dårlig

$\square$ Dårlig

$\square$ Rimelig

$\square$ God

$\square$ Svært god

c) Din evne til å få orgasme (klimaks)

$\square$ Svært dårlig

$\square$ Dårlig

$\square$ Rimelig

$\square$ God

$\square$ Svært god

47. Hvordan er vanligvis GRADEN av stivhet ved ereksjon?

$\square$ Ingen ereksjon (reisning)

$\square$ Ikke stiv nok til seksuell aktivitet

$\square$ Bare stiv nok til onanering og forspill

Tilstrekkelig stivhet for samleie

48. Hvor OFTE har du oppnådd ereksjon når det har vært ønskelig?

$\square$ Aldri ereksjon når jeg har ønsket det

$\square$ Mindre enn halvparten av tiden

$\square$ Omtrent halvparten av tiden

Mer enn halvparten av tiden

$\square$ Alltid ereksjon når det har vært ønskelig

49. Hvor ofte har du våknet om morgenen eller natten med ereksjon?

$\square$ Aldri

Sjelden (mindre enn $25 \%$ av tiden)

$\square$ lkke ofte (mindre enn halvparten av tiden)

Ofte (mer enn halvparten av tiden)

$\square$ Veldig ofte (mer enn $75 \%$ av tiden) 
50. Har du gjennomført samleie i løpet av de siste 4 ukene?

$\square \mathrm{Nei}$

$\square$ Ja, en gang

$\square$ Ja, mer enn en gang

51. Hvordan vil du karakterisere din evne til å fungere seksuelt de siste 4 ukene?

$\square$ Svært dårlig

$\square$ Dårlig

$\square$ Rimelig

$\square$ God

$\square$ Svært god

52. Har du brukt tabletter utskrevet av lege for å bedre seksuell funksjon (potens) i løpet av de siste 4 ukene?

$\square$ Alltid

$\square$ Oftest

$\square$ Sjelden

$\square$ Aldri

53. Har du satt sprøyte/ injeksjon i penis for å få bedre ereksjon i løpet av de siste 4 ukene?

$\square$ Alltid

$\square$ Oftest

$\square$ Sjelden

$\square$ Aldri

54. Hvordan vil du beskrive din evne til å gjennomføre samleie uten, eller eventuelt med tabletter eller sprøyter i løpet av de siste 4 ukene?

a) Uten tabletter eller sprøyter

$\square$ lkke aktuelt

$\square$ lkke ereksjon, samleie ikke mulig

$\square$ Samleie mulig i mindre enn halvparten av forsøkene

$\square$ Samleie mulig ved de fleste forsøk

$\square$ Samleie alltid mulig

b) Med tabletter for potens (ikke sprøyter)

$\square$ lkke aktuelt

$\square$ lkke ereksjon, samleie ikke mulig

$\square$ Samleie mulig i mindre enn halvparten av forsøkene

$\square$ Samleie mulig ved de fleste fors $\varnothing k$

$\square$ Samleie alltid mulig

c) Etter bruk av sprøyter i penis

$\square$ lkke aktuelt

$\square$ Ikke ereksjon, samleie ikke mulig

$\square$ Samleie mulig i mindre enn halvparten av forsøkene

$\square$ Samleie mulig ved de fleste forsøk

Samleie alltid mulig 
55. Hvor stort problem totalt sett har din seksualfunksjon vært for deg de siste 4 ukene?

$\square$ lkke noe problem

$\square$ Svært lite problem

$\square$ Lite problem

$\square$ Moderat problem

$\square$ Stort problem

56. Har du hatt smerter eller ubehag i forbindelse med orgasme/ utløsning?

$\square$ Alltid

$\square$ Oftest (mer enn halvparten av gangene)

$\square$ Ganske ofte (omtrent halvparten av gangene)

$\square$ Sjelden (mindre enn halvparten av gangene)

$\square$ Aldri

\section{Hormonelle forhold}

57. Hvor stort problem, om noe, har hvert av de følgende vært for deg de siste 4 ukene?

a) Hetetokter

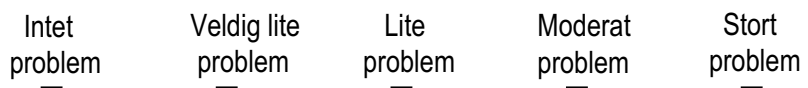

b) Ømme/ svulne bryster/ brystvorter

c) Tap av hår på kroppen

d) Følt deg nedstemt

e) Manglet energi

f) Vektøkning

g) Vektreduksjon 

I 



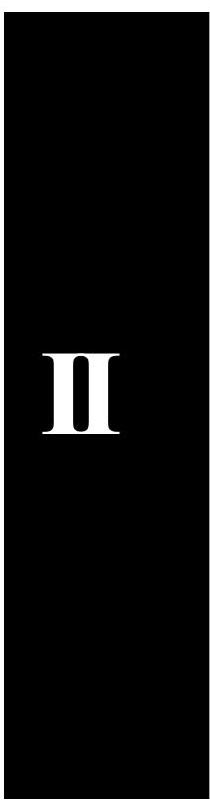





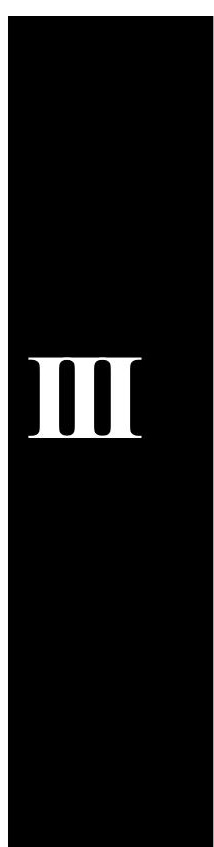


